\title{
De la centralidad de la ley al primado de la persona en el Derecho de la Iglesia. Historia y perspectivas canónicas en el centenario del Código de 1917*
}

\author{
From the Centrality of the Law to the Primate of the Person \\ in the Law of the Church. History and Canonical \\ Perspectives on the Centenary of the Code of 1917
}

Valentín GómeZ-IGLESIAS C.

Profesor Ordinario de Derecho Constitucional Canónico Universidad de Navarra. Facultad de Derecho Canónico orcid 0000-0003-3927-7624

valentingic@unav.es

Resumen: El autor pone de manifiesto cómo el primer Código de Derecho Canónico, del que ahora se celebra el centenario, es una piedra miliar en la bimilenaria historia jurídica de la Iglesia. Con el Código de 1917 se pasó de un modo de producción del Derecho de corte preponderantemente «jurisprudencial» a otro de tipo «legislativo»: la autoridad del Código no proviene ya de sus contenidos jurídicos en cuanto tales sino de su promulgación por el Legislador. Se asignaba así el puesto central en el Derecho canónico a la Ley, al Legislador. Sin embargo, por la aportación de concepciones integradoras de la doctrina científica y por las enseñanzas del magisterio eclesial, esa centralidad de la Ley va cediendo el primado a la persona a su dignidad y libertad, a sus derechos y deberes fundamentales. Proclamar ese primado continúa siendo un objetivo de la ciencia del Derecho canónico contemporánea.

Palabras clave: Codex luris Canonici 1917, Codificación, Método exegético, Método sistemático, Antijuridicismo, Derechos de los fieles.
Abstract: The author shows how the first Code of Canon Law, now one hundred years old, is a milestone in the two-thousand legal history of the Church. The 1917 Code marked a shift from a «jurisprudential» to a «legislative» mode of law: the authority of the Code no longer comes from its legal contents as such but from its promulgation by the legislator. Thus, the law and the legislator are assigned central roles in canon law. However, in a more comprehensive understanding of the doctrine and ecclesial magisterium in this regard the centrality of the law as such has begun to yield to the person: the dignity and freedom, the fundamental rights and duties of the person. Contemporary canon law continues to articulate the primacy of the person.

Keywords: Codex luris Canonici 1917, Codification, Exegetical Method, Systematic Method, Antijuridicism, Rights of the Faithful.

\footnotetext{
* Lección inaugural del curso académico 2017-2018 en la Universidad de Navarra (15 de septiembre de 2017).
} 


\section{El «CODEX IURIS CANONICI» DE 1917 y LA CENTRALIDAD DE LA LEY}

\subsection{La elaboración y promulgación del «Codex Iuris Canonici» de 1917}

E legido el 4 de agosto de 1903, San Pío X, ya en los primeros meses de su Pontificado, puso en marcha el grandioso trabajo de la Codificación ${ }^{1}$ del Derecho canónico, que suscitó una movilización sin precedentes de casi quince años de duración. Cuando falleció San Pío X, el 20 de agosto de 1914, la redacción del Código estaba en fase muy avanzada: el Papa Sarto imprimió una gran celeridad a todo el trabajo, especialmente en su fase final, como alimentando la esperanza -así lo testimonia su Secretario de Estado, el Cardenal Merry del Val- «de ver terminada esta grandiosa reforma durante su vida ${ }^{2}$. El estallido de la Gran Guerra en el verano de 1914 y la elección del nuevo Papa, el 3 de septiembre de ese año, retrasaron el acontecimiento de su promulgación: en 1916 pudo ya entregarse a la imprenta un proyecto completo de todo el Código y anunciarse que sería promulgado en la fiesta de Pentecostés el 27 de mayo de 1917. Efectivamente, por medio de la Constitución Apostólica «Providentissima Mater Ecclesia» ${ }^{3}$, su sucesor Benedicto XV promulgaba el «Codex iuris canonici Pii $\mathrm{X}$ pontificis maximi iussu digestus Benedicti papae $\mathrm{XV}$ auctoritate promulgatus $»^{4}$, publicándose un mes más tarde,

${ }^{1}$ Sobre la Codificación del Derecho canónico, contamos hoy con una obra imponente en la que se estudia con perspectiva histórica el Código de 1917, no solamente afrontando los precedentes inmediatos de su elaboración, sino encuadrándolo en el amplio itinerario de la modernidad jurídica que surge después del Concilio de Trento: C. FANTAPPIÈ, Chiesa Romana e modernità giuridica, Milano 2008, 1282 pp. Los preciosos datos históricos aportados son al mismo tiempo interpretados por el autor y como toda interpretación ha dado y dará lugar a un fructífero diálogo científico: «Dialogo che si fonda nell'accettazione dei dati storici da lui presentati in modo magistrale, ma che forse permettono altre letture o almeno una lettura più sfumata delle sue conseguenze per il diritto canonico odierno» (N. Álvarez DE las Asturias, Il Codice di Diritto Canonico del 1917 quale oggetto storico, Ius Ecclesiae 23 (2011) 745-763: 747). Vid. también, J. SEDANO, Iglesia y modernidad jurídica. Una contribución a la Historia del pensamiento jurídico moderno en la monografía de Carlo Fantappiè, Ius Canonicum 52 (2011) 767-798. Recientemente ha visto la luz una monografía del mismo autor: C. FANTAPPIÈ, Ecclesiologia e Canonistica, Venezia 2015, 439 pp.; vid. la recensión de esta obra también de N. ÁlVAREZ DE LAS ASTURIAS, Revista Española de Teología 76 (2016) 530-535.

2 R. Merry Del VAL, Pio X (Impressioni e ricordi), Padova 1925, 96 [Si no se dice otra cosa, las traducciones al castellano del cuerpo del texto son mías].

3 AAS 9 (1917) 5-8.

${ }^{4}$ Sobre el Codex Iuris Canonici de 1917, pueden verse las ya clásicas publicaciones: F. RUfFINI, La codificazione del Diritto ecclesiastico, Prato 1905, en IDEM, Scritti giuridici minori, a cargo de M. FALCO - A. C. Jemolo - E. RuffinI, vol. I, Milano 1936, 59-97; J. Noval, Codificationis juris canonici: recensio historico-apologetica et Codicis piano-benedictini notitia generalis; doctrina ad studium novi Codicis Canonici propaedeutica, Romae 1918; U. STUTZ, Der Geist des Codex iuris canonici, Stuttgart 
el 28 de junio, en «Acta Apostolicae Sedis», para entrar en vigor el 19 de mayo de 1918, Solemnidad de Pentecostés. El «Codex» de 1917, cuyo centenario se está celebrando este año con múltiples manifestaciones culturales y científicas, constituye una piedra miliar en la bimilenaria historia jurídica de la Iglesia ${ }^{5}$. El Código incluyó casi todo el Derecho canónico vigente en la Iglesia latina en 2.414 cánones, que en su forma y estructura imitaban los artículos de los Códigos estatales ${ }^{6}$.

\footnotetext{
1918; M. FalCO, Introduzione allo studio del «Codex iuris canonici», a cargo de G. FeliCIANI, Bologna ${ }^{2} 1992$ (Torino ${ }^{1} 1925$ ); P. GASPARRI, Storia della codificazione del diritto canonico per la Chiesa latina, en Acta Congressus Iuridici Internationalis VII saeculo a Decretalibus Gregorii IX et XIV a Codice Iustiniano promulgatis, Romae 12-17 novembris 1934, vol. IV, Romae 1937, 3-10; A. VETULANI, «Codex Iuris Canonici», en Dictionnaire de droit canonique, a cargo de R. NAZ, vol. III, Paris 1942, 910-935; S. KuTTNER, Il Diritto canonico nella storia, Jus 18 (1967) 239-254; A. M. STICKLER, La funzione della scienza storica di diritto canonico nella codificazione pio benedettina e per la riforma attuale del diritto canonico, L'année canonique 15 (1971) 525-540. Pueden consultarse otras aportaciones más recientes: R. AsTORRI, La canonistica di fronte al CIC 17, en L'eredità giuridica di San Pio X, a cargo de A. Cattaneo, Venezia 2006, 173-183; G. Dalla Torre, Pio X e il Codice di diritto canonico, Archivio Giuridico 221 (2001) 55-75 y en Pio X e il suo tempo, a cargo de G. LA BELla, Bologna 2003, 311-332; C. FANTAPPIÈ, Gli inizi della codificazione pio-benedettina alla luce di nuovi documenti, Il diritto ecclesiastico 93 (2002) 16-83; IDEM, Per la storia della codificazione canonica (A cento anni del suo avvio), Ius Ecclesiae 16 (2014) 41-65; IDEM, Pio X e il «Codex iuris canonici», en L'eredità giuridica..., cit., 155-171; G. FELICIANI, Il Concilio Vaticano I e la codificazione del diritto canonico, en Studi in onore di Ugo Gualazzini, vol. II, Milano 1981, 35-80; IDEM, Lineamenti di ricerca sulle origini della codificazione canonica vigente, en Università di Macerata. Annali della Facoltà di Giurisprudenza in onore di Attilio Moroni, n.s., vol. V, t. I, Milano 1982, 205-225; IDEM, Il Cardinale Gasparri e la codificazione del diritto canonico, en Studi in onore di Gaetano Catalano, vol. I, Soveria Mannelli 1998, 563-587; IDEM, «Codex Iuris Canonici (1917)», en Diccionario General de Derecho Canónico, vol. II, Pamplona 2012, 167-172; P. GHERRI, Il primo Codice di diritto canonico: fu vera codificazione?, Apollinaris 76 (2003) 827-898; P. GrossI, Storia della canonistica moderna e storia della codificazione, Quaderni fiorentini per la storia del pensiero giuridico moderno 14 (1985) 587-599; IDEM, Valori e limiti della codificazione del diritto (con qualche annotazione sulla scelta codicistica del legislatore canonico), en L'eredità giuridica..., cit., 141-154; J. LLOBELL - E. DE LEÓN - J. NAVARRETE, Studio introduttivo, en Il libro «De processibus» nella codificazione del 1917, vol. I, Milano 1999, 17-228; A. Motilla, La idea de codificación en el proceso de formación del Codex del 1917, Ius Canonicum 28 (1988) 681-720; C. REDAELLI, La adozione del principio della codificazione: significato ecclesiologico soprattutto in riferimento alla ricezione, en La recepción y la comunión entre las Iglesias, a cargo de H. Legrand - J. Manzanares - A. García y García, Salamanca 1997, 315-348; IDEM, Codificación [Cuestión de la], en Diccionario General de Derecho Canónico, vol. II, Pamplona 2012, 189-196; C. SalinaS-ARANEDA, La codificación del Derecho Canónico del 1917, Revista de Derecho de la Pontificia Universidad Católica de Valparaíso 30 (2008) 311-356; P. VALDRini, Pio X e l'elaborazione del Codex Iuris Canonici, en San Pio X papa riformatore di fronte alle sfide del nuovo secolo, a cargo de R. REGOLI, Città del Vaticano 2016, 121-130.

5 «La decisione, l'impostazione, l'orientamento e le modalità tecniche di formazione e di attuazione del Codex iuris canonici costituiscono un tornante decisivo, se non addirittura epocale, della storia del diritto canonico latino» (C. FANTAPPIE, Pio X e il «Codex...», cit., 155).

${ }^{6}$ Para lo que sigue, vid. V. GómeZ-IgLEsias C., Acerca de la trascendencia bistórica de la iniciativa de San Pio X de elaborar un Código de Derecho canónico, Ius Ecclesiae 29 (2017) 51-76.
} 


\subsection{El estado de las fuentes canónicas}

La Iglesia a lo largo de la Historia ha ido elaborando su Derecho ${ }^{7}$. Desde mediados del siglo XII hasta comienzos del siglo XIV la elaboración de ese Derecho adquiere su mayor creatividad y riqueza: estamos ante lo que se conoce como la Época clásica o Edad de oro del Derecho canónico. Una vez que Graciano en su célebre Decreto «Concordia discordantium canonum» (año 1140?) sintetizó la tradición jurídica de la Iglesia, los Papas comenzaron una gran producción de Decretales: se trata de las soluciones o respuestas concretas a través de las cuales los Papas resuelven, caso por caso, los problemas jurídicos que se les plantean. Es una técnica muy parecida a la del rescripto del Derecho romano. Esas soluciones no se aplicaban solamente al caso concreto, sino también a los casos análogos que fuesen surgiendo: estamos ante un modo de producir Derecho preponderantemente «jurisprudencial», ya que habitualmente no se daban normas abstractas en las que encajaban los supuestos de hecho, sino que se partía de la solución al caso concreto para aplicarlo a otros casos análogos. Por eso, las Decretales se compilan o coleccionan: las Decretales de Gregorio IX de 1234; el Libro Sexto de Bonifacio VIII de 1298; las Decretales Clementinas de Juan XXII de 1317.

Hay constancia de que un siglo más tarde de estas últimas Decretales, en los inicios del siglo XV, empieza a denominarse el Decreto de Graciano y estas tres Colecciones de Decretales como «Corpus Iuris Canonici» que, con diversas vicisitudes históricas, es Derecho vigente en la Iglesia hasta el «Codex Iuris Canonici» de 1917: seis siglos pasaron desde aquel año 1317 de las «Decretales Clementinas» hasta la promulgación del «Codex» el año 1917. Desde la edición romana del «Corpus Iuris Canonici», publicada por Gregorio XIII en 1582, que incluía, además de las Colecciones mencionadas, las Extravagantes de Juan XXII y las Extravagantes comunes, no hubo una nueva Colección de Decretales ni una recopilación que sirviese de complemento y actualización del «Corpus». Después del Concilio de Trento (años 1545-1563),

\footnotetext{
Sobre la Historia del Derecho canónico, pueden verse, entre otros, A. VAN HovE, Commentarium lovaniense in Codicem Iuris Canonici. Prolegomena, Altera, Mechliniae-Romae 1945; A. M. STICKLER, Historia juris canonici latini. Institutiones academicae, vol. I, Historia Fontium, Taurini 1950; F. Calasso, Medio Evo del Diritto, vol. I, Le fonti, Milano 1954; J. Hervada - P. Lombardía, El Derecho del Pueblo de Dios. Hacia un sistema de Derecho Canónico, vol. I, Introducción. La Constitución de la Iglesia, Pamplona 1970, 59-144, 189-225; A. PRIETO, El proceso de formación del Derecho canónico, en Derecho Canónico, Pamplona 1975, 89-138; J. ForNÉs, La ciencia canónica contemporánea (Valoración crítica), Pamplona 1984, 235-295.
} 
crecieron las fuentes canónicas en número, en complejidad, en variedad y en dispersión ${ }^{8}$. La actividad legislativa de los sucesivos Romanos Pontífices fue muy abundante y se promulgaron multitud de documentos: Bulas, Breves, y otros similares. Fue abundante también la producción normativa y disciplinar de la Curia Romana, sobre todo a través de sus Congregaciones, que dio lugar a un ingente número de documentos, que a veces se fueron recopilando con un puro criterio cronológico. Hubo también un notable desarrollo de los Sínodos diocesanos, cuyas constituciones sinodales se imprimieron con frecuencia, dando lugar a un tipo de fuentes particulares muy dispersas. El transcurso de los años, aunque no disminuyó el prestigio histórico del «Corpus Iuris Canonici», aumentó su incapacidad para solucionar los problemas de los tiempos nuevos, que se afrontaron a través de todo ese abundante, complejo, variado y disperso material normativo que va poco a poco rebasando al «Corpus» en importancia ${ }^{9}$. El acceso a la norma aplicable se convirtió en algo intrincado y, en cierta manera, sofisticado; como intrincado y difícil fue determinar los límites entre lo vigente y lo derogado o caído en desuso. El Derecho canónico era «una intrincada foresta cuyas ramas vivas y muertas se entrelazaban mutuamente» ${ }^{10}$. Muchos Padres del Concilio Vaticano I (años 18691870) hicieron hincapié en la situación de incertidumbre jurídica en la vida de la Iglesia y en la necesidad de ordenar las fuentes, eliminar las normas derogadas y adecuar las restantes a los nuevos tiempos; así se lograría la certeza del Derecho, la facilidad en el manejo de las fuentes y un conocimiento de ellas accesible incluso al no experto en Derecho canónico. Discrepaban, respecto a las fórmulas concretas: o una nueva Colección canónica o un Código de tipo moderno como en los Estados civiles ${ }^{11}$. Ni Pío IX ni León XIII por variadas circunstancias acometieron ese ingente trabajo; pero San Pío X, inmediatamente después de su elección, en 1904, ordenó realizar ese trabajo instituyendo para ello una Comisión pontificia: en el seno de la Curia romana se manifestaron también esas ya antiguas discrepancias acerca del modo de proceder: o Colección o Código. El Papa Sarto tomó posición clara en favor de utilizar la moderna técnica legislativa estatal de la Codificación, pero puesta al servi-

\footnotetext{
${ }^{8}$ Vid. J. Hervada - P. Lombardía, El Derecho del Pueblo de Dios..., cit., 118-121.

9 A. Motilla, La idea de codificación..., cit., 683-684.

10 S. KuTTNer, Il Diritto canonico..., cit., 241.

11 Entre los trabajos sobre este tema es de destacar el de G. Feliciani por el minucioso estudio de todas las actas del Concilio, G. Feliciani, Il Concilio Vaticano I..., cit. Vid. también C. Fantappiè, Chiesa Romana..., cit., 543-556 y A. Motilla, La idea de codificación..., cit., 684-687, 690-698.
} 
cio no de llevar a cabo una reforma profunda del Derecho canónico sino de recoger, en un cuerpo legal manejable y en formulaciones claras y sintéticas, las leyes canónicas recibidas del pasado.

\subsection{El principio de la Codificación y la técnica codificadora}

La situación del Derecho canónico, hasta aquí descrita, era común al Derecho de las sociedades civiles y poco a poco en la Ciencia jurídica se había ido abriendo paso el principio de la Codificación. El contexto histórico de la Codificación es la concepción filosófica de la Ilustración de dar primacía a la razón humana también en el campo del Derecho: es posible llegar a un Derecho racional, universal y válido para todos. La formulación de este Derecho debería ser racional, sistemática, completa, sencilla y fácil de entender: es decir, el Código. El Código resolvería, desde el punto de vista práctico, la necesidad de poner orden en las fuentes jurídicas, confusas e inciertas, y también dejar atrás formulaciones jurídicas que no se adaptaban a los nuevos tiempos. Además había otras razones de carácter político: la idea de reconducir todo el Derecho a la ley, una ley racional, absoluta y completa, promulgada por un único y soberano legislador, cuya interpretación se reservaba también a ese mismo autor de la ley; a la doctrina le competía sólo comentarla y al juez aplicarla, sin interpretación alguna. Este conjunto de causas y motivos llevó al nacimiento de los «Códigos» ${ }^{12}$. El primero que vio la luz y fue modelo de todo el movimiento codificador fue el «Code Civil des Français» o de Napoleón del año $1804^{13}$.

La Constitución Apostólica de promulgación del «Codex Iuris Canonici» de 1917 no dice nada de sus características peculiares. Se ha escrito, resumiendo, que dos fueron las novedades absolutas introducidas por el Papa Sar-

12 C. ReDAELLi, Codificación..., cit., 191. «Un aspecto interesante es que los diferentes códigos, desde el punto de vista de los contenidos, no presentaban un derecho ex novo, sino que recogían en gran medida el derecho común anterior. La obra del legislador al elaborarlos era sobre todo de carácter formal, y consistía en "unificar y hacer racionales" esos contenidos jurídicos, mediante la formulación típica del código» (ibid.).

${ }^{13}$ Contra el principio de la Codificación y su formalización en un Código como el «Code» napoleónico, reacciona muy pronto Savigny, el más genuino representante de la Escuela Histórica alemana, en su famosa controversia del año 1814 con Thibaut que marca profundamente el desarrollo no sólo del pensamiento y trabajo científico de Savigny y posteriores discípulos sino también de toda la Escuela histórica a lo largo del siglo XIX y comienzos del XX. En la controversia los dos autores expusieron de forma programática su visión del Derecho y su consiguiente posicionamiento sobre el tema de la Codificación. Vid. A. F. J. Thibaut - F. C. SaVigny, La polemica sulla codificazione, a cargo de G. MARINI, Napoli 1982. 
to: a) codificar el Derecho canónico y b) codificarlo todo entero ${ }^{14}$. Ciertamente, a diferencia de las Colecciones y de las compilaciones canónicas precedentes, el Código, en cuanto a la forma, se presenta como fuente exclusiva del Derecho canónico vigente, con la pretensión de contener, según los límites prefijados por el legislador, toda la legislación positiva de la Iglesia. Además, el Código también manifiesta una de las características propias de la Codificación: la sistematización. No sólo pretende unificar sino proceder a una reorganización metódica y jerarquizada del Derecho de la Iglesia. Es verdad que el Código de 1917, pertenece al género de los demás Códigos del siglo XIX: concretamente se aproxima en cuanto a la técnica al «Code» de Napoleón y a sus derivados. Sin embargo, la bibliografía reciente suele reconocer las caraterísticas peculiares del «Codex Iuris Canonici», que lo diferencian de los diversos y variados Códigos estatales, al mismo tiempo que reafirma el papel central del Papa Sarto en su realización, que lo veía como el coronamiento de todas sus numerosas reformas en el seno de la Iglesia ${ }^{15}$. Estas peculiaridades manifiestan la pretensión de sustancial continuidad que se encuentra en la Iglesia en cada momento histórico de reforma. La asunción del principio y de la técnica de la Codificación fue deliberadamente limitada para hacerla conforme a la especificidad del Derecho canónico. «Se habría así idealmente logrado conjugar sus ventajas prácticas (mayor claridad y certeza) y "políticas" (presentación de la Iglesia en el mundo en pie de igualdad con los distintos Estados) sin comprometer ni la sustancia ni el espíritu peculiar que anima el derecho canónico y su desarrollo histórico» ${ }^{16}$.

Por otro lado, hay que señalar que el «Código»-como no podía ser de otro modo- convirtió en lenguaje jurídico las enseñanzas doctrinales y magisteriales sobre la Iglesia, en la profundización histórica concreta después del Concilio Vaticano I, que hacían especial hincapié en los aspectos hierarcológicos y en la potestad de jurisdicción o de régimen que por Derecho divino compete a la autoridad jerárquica, dejando más desdibujados y sin profundizar otros aspectos. Estas enseñanzas están ciertamente «en el origen de la

${ }^{14}$ C. FANTAPPIÈ, Chiesa Romana ..., cit., 1106.

${ }^{15}$ N. Álvarez De las Asturias, Derecho canónico y codificación: Alcance y límites de la asunción de una técnica, Ius Canonicum 51 (2011) 105-136: 118-120; C. FANTAPPIÈ, Chiesa Romana ..., cit., 10521061; G. FelicianI, «Codex Iuris Canonici...», cit., 170; P. GRossi, Valori e limiti della codificazione del diritto..., cit., 142-145; A. PADOA SCHIOPpa, Storia del diritto in Europa. Dal medioevo all'età contemporanea, Bologna 2007, 597; P. VALDRINI, Pio X e l'elaborazione..., cit., 126-130.

16 N. Álvarez de las Asturias, Derecho canónico..., cit., 119. 
construcción del ordenamiento positivo canónico como prevalente cuadro disciplinar o ampliamente normativo de la actividad de la jerarquía y de las condiciones personales de aquellos que son miembros de ella y de aquellos que testimonian en un particular estado de vida (vida consagrada) la llamada a la santidad ${ }^{17}$. No puede extrañar que el «Código» de 1917 sea tributario de la imagen de la Iglesia que se tenía en los años de su redacción. Esto no es una limitación de su técnica sino manifestación de su particular perfección ${ }^{18}$. «Otra cosa, bien distinta, es que hoy deban considerarse superados buena parte de los presupuestos doctrinales que sirvieron de base a las articulaciones técnicas de aquella codificación ${ }^{19}$.

Sea de ello lo que fuere, el hecho que nos interesa resaltar aquí es que con el «Codex Iuris Canonici» de 1917 se produce un cambio epocal: el paso de un modo de producción del Derecho de tipo preponderantemente «jurisprudencial» a otro de tipo «legislativo». La autoridad del «Codex» no proviene de los textos jurídicos recogidos, ordenados y sistematizados, en cuanto tales, sino de la promulgación por el legislador canónico. Se consagra en el Derecho canónico la centralidad de la ley y la centralidad del legislador.

\subsection{La normativa de aplicación del «Codex»: interpretación y enseñanza ${ }^{20}$}

La valoración del «Codex»y de la ideas y objetivos que personalmente el Papa Sarto se propuso con la Codificación canónica, no puede separarse, pero sí distinguirse, de la valoración de la aplicación que se hizo del «Codex»

17 G. Lo CaStro, Il soggetto e i suoi diritti nell'ordinamento canonico, Milano 1985, 50. «Su queste osservazioni critiche, non sembra opportuno insistere eccessivamente, [...] per una ragione di correttezza scientifica, giacché non sarebbe stato né probo né possibile rimproverare al legislatore del 1917 impostazioni e carenze che solo successive acquisizioni dottrinali e magisteriali avrebbero rivelato nella loro reale portata $[\ldots] \gg($ ibid., 52).

$18 \ll$ Los redactores del Codex lograron con sus formulaciones resultados congruentes con una visión de la Iglesia que -prescindiendo de antecedentes más remotos: reforma gregoriana y tridentina- se afianza en el encuentro con el laicismo liberal y está ya plenamente presente, en el plano legislativo, en la Const. Apostólica Sapienti Consilio [29 de junio de 1908]» (P. LomBARDÍA, Técnica jurídica del nuevo Código [Una primera aproximación al tema] [en Temas fundamentales del nuevo Código. Actas de la XVIII Semana Española de Derecho Canónico, abril 1983, Salamanca 1984, 145-168], en IDEM, Escritos de Derecho Canónico y de Derecho Eclesiástico del Estado, vol. V, Pamplona 1991, 187-221: 194).

19 Ibid., 195.

${ }^{20}$ Para lo que sigue, vid. V. GÓmeZ-Iglesias C., La ricezione del Codice del 1917 nella dottrina e nell'insegnamento, en La Codificazione e il Diritto nella Chiesa, a cargo de E. BAURA - N. ÁLVAREZ DE LAS ASturias - T. SOL, Milano 2017, 71-119. 
y de sus efectos. Como también pueden distinguirse entre sí los Papas San Pío $\mathrm{X}$ y Benedicto XV, y sus respectivos Secretarios de Estado, Cardenal Rafael Merry del Val y Cardenal Pietro Gasparri, respectivamente.

Se ha insistido en que el «Codex» del 1917 no es simplemente una copia del modelo francés del «Code Napoléon», que el «Codex» tiene unas características propias que lo distinguen no tanto en la forma cuanto en el contenido del modelo francés. Pero también se ha señalado el peligro de una asimilación general al modelo utilizado, de transformar todo el Derecho canónico en Derecho «legislado»y al final en Derecho «codificado», porque la peculiar técnica de la codificación parece tener una vocación a la plenitud, a la autorreferencialidad, a la exclusividad. En esta línea, parece que las normas que acompañaron la promulgación del «Codex» asumieron explícitamente algunos principios subyacentes a la técnica codificadora que acercaron el «Codex» de 1917 a su modelo francés y sus derivados mucho más de cuanto parece que se pretendía, tanto en la idea original de San Pío X y de la Comisión Pontificia Codificadora como en la consiguiente formulación de los cánones 1 a 7 y 20 del Código de 1917.

En primer lugar, y por lo que respecta a la doctrina, hay que considerar el Motu Proprio «Cum iuris canonici» de Benedicto XV, de 15 de septiembre de $1917^{21}$. El objetivo declarado del Motu Proprio fue evitar que la interpretación privada o la variedad frecuente de nuevas leyes, pusieran en peligro la estabilidad de una obra de tanta importancia. Por eso, la interpretación «auténtica» de sus cánones será reservada a un organismo pontificio («Consejo o Comisión») a imitación del que se estableció al acabar el Concilio de Trento para la interpretación auténtica de sus Decretos ${ }^{22}$. Además, para evitar el incremento de nuevas leyes, se prohibió a las Congregaciones romanas dar «Decretos Generales» y limitarse a publicar, si fuese el caso, «Instructiones» que fuesen sólo explicaciones o complementos de las prescripciones del Código ${ }^{23}$.

${ }^{21}$ AAS 9 (1917) 483-484.

22 El primer Presidente de la Pontificia Comisión para la interpretación auténtica de los cánones del Código fue el Cardenal Gasparri, Secretario de Estado, nombrado Presidente por Benedicto XV el 18-X-1917, unas semanas después de la promulgación del M. P. Cum iuris canonici (15IX-1917), y se mantuvo en ese cargo hasta que cesó como Secretario de Estado el 7-II-1930, a mitad del pontificado de Pío XI (1922-1939). Falleció el 18-XI-1934.

${ }^{23}$ La Comisión emitirá numerosas respuestas de interpretación auténtica: esta reserva exclusiva de la interpretación producirá efectos negativos sobre la jurisprudencia y la doctrina, análogos a los que padeció el Derecho canónico tridentino (C. FANTAPPIÈ, Chiesa Romana..., cit., 1153-1154). 
En segundo lugar, y por lo que atañe a la enseñanza, hay que referirse a dos documentos de la $\ll$ S. Congregatio de Seminariis et de Studiorum Universitatibus» publicados en los meses siguientes a la promulgación del «Codex Iuris Canonici». En uno de ellos, será afirmado de modo categórico que el «Codex» es «authenticum et unicum iuris canonici fontem» de la Iglesia latina. Esta locución acabará por ser empleada como una certificación del carácter exclusivo y excluyente del Derecho codificado en el «Codex», al igual que sucede con los otros Códigos de los Estados. Esa locución es parte integrante de la Instrucción «Cum novum iuris» de 7 de agosto de 1917 con la que la Congregación de Seminarios y Universidades establecía el método en la enseñanza e interpretación del $\ll$ Codex» ${ }^{24}$. La Instrucción, partiendo del dato incontrovertible de que el «Codex» es la «auténtica y única fuente del Derecho canónico», establece que «tanto en la aplicación de la disciplina de la Iglesia como en los juicios y en las escuelas "eo uno utendum esse"». Consiguientemente, se establece que en todas las instituciones docentes dependientes de la Congregación, en la «schola textus»-«aptissime nuncupata»- el «Codex» se explique no sintéticamente sino con un cuidadoso análisis canon por canon, «religiosissime servata» la sucesión numérica, con los títulos y los capítulos del propio «Codex». Los profesores o doctores deben «singulos canones diligenti explanatione interpretari». Acaba la instrucción precisando que ningún libro es necesario a los alumnos fuera del Código: «nullo ceterum, praeter Codicem, libro alumnos uti necesse erit». El otro documento es un Decreto de la misma Congregación «Legum canonicarum Codice» - «De experimentis ad gradus in iure canonico assequendos» de 31 de octubre de $1918^{25}$. En coherencia con la Instrucción de 1917 se establecen tres prescripciones: a) los exámenes deben tener por objeto los cánones del Código y no temarios o elencos de doctrina; b) para conseguir los grados académicos los candidatos deben exponer la «exégesis» e «interpretación» de los cánones, tomados singularmente o relacionados entre ellos; y c) los candidatos deben poder hacer una exposición para cada instituto acerca de su origen, progreso e historia. Tales indicaciones lógicamente favorecieron la asimilación del método canónico al método de «l'école de l'exégèse» y, por lo que aquí nos interesa, acentuaron

${ }^{24}$ S. Congregatio de SeminariIs et de Studiorum Universitatibus, Inst. Cum novum iuris De novo Iuris Canonici Codice in Scholis proponendo, 7-VIII-1917, AAS 9 (1917) 439.

25 S. Congregatio de Seminaris et de STUdiorum Universitatibus, Decr. Legum canonicarum Codice - De experimentis ad gradus in Iure Canonico assequendos, 31-X-1918, AAS 11 (1919) 19. 
la homologación del Derecho canónico a los Derechos codificados estatales, consagrando la centralidad y exclusividad de la ley canónica positiva y la posición preeminente y central del legislador en el Derecho de la Iglesia.

El 7 de febrero de 1930, a mitad del Pontificado de Pío XI, cesó el Cardenal Pietro Gasparri como Secretario de Estado y como Presidente de la Comisión de interpretación auténtica de los cánones del Código. Las rígidas normas emanadas en 1917 y 1918 se flexibilizaron poco a poco en su aplicación y la propia Santa Sede dio paso a criterios más abiertos en la Constitución Apostólica «Deus scientiarum Dominus» - «De Universitatibus et Facultatibus Studiorum Ecclesiasticorum» de Pío XI, de fecha 24 de mayo de 1931 , y en las sucesivas «Ordinationes» para su recta aplicación, de la S. Congregación de Seminarios y Universidades ${ }^{26}$. El núcleo de la enseñanza del Derecho canónico, como en la normativa anterior de 1917-1918, sigue siendo el «Codex» con algún complemento que flexibilizaba un poco la rigidez de dicha normativa: cinco materias principales de «schola textus», correspondientes cada una de ellas a cada uno de los cinco libros del Código con su mismo título o rúbrica codiciales; a esas cinco disciplinas principales se añadían ahora dos también principales - «Introducción a las ciencias jurídicas (Derecho natural, Filosofía del derecho)» y «Ius publicum ecclesiasticum»-. El método exegético sigue siendo el principal, tanto en la enseñanza como en los manuales y comentarios destinados a la docencia: la centralidad de la ley canónica positiva en el Derecho de la Iglesia es de nuevo reafirmada. Hay que hacer notar que estas normas de 1931, con todo lo que suponen y se ha recordado ahora, estuvieron vigentes casi medio siglo, hasta la promulgación por San Juan Pablo II, el 15 de abril de 1979, de la Constitución Apostólica «Sapientia Christiana» - «De Studiorum Universitatibus et Facultatibus ecclesiasticis» y las «Ordinationes» para su recta aplicación, de la S. Congregación para la Educación Católica de 29 de abril del mismo año ${ }^{27}$. Aunque el artículo 75 de esta Constitución define la finalidad de la Facultades de Derecho Canónico con una mayor apertura de horizonte ${ }^{28}$, sin embargo la Congregación para la Educación Católica, vuelve a dar una visión de la enseñan-

\footnotetext{
26 AAS 23 (1931) 241-284.

27 AAS 71 (1979) 469-521.

$28 \ll$ Facultas Iuris Canonici, Latini vel Orientalis, disciplinas canonisticas in lumine legis evangelicae excolere ac provehere intendit, in iisdemque studentes altius instituere ut ad investigationem et magisterium formentur necnon ad peculiaria munera ecclesiastica obeunda praeparentur» (art. 75).
} 
za del Derecho canónico teñida de colores exegéticos y, en cierta manera, de tonos positivistas, reproduciendo al pie de la letra el contenido del artículo 29 de la «Deus Scientiarum Dominus»: «In Facultate Iuris Canonici, Latini vel Orientalis, curandum est ut tum historia et textus legum ecclesiasticarum tum earundem ratio et nexus modo scientifico exponantur $»-\ll$ En la Facultad de Derecho Canónico, Latino u Oriental, se ha de cuidar con esmero que tanto la historia y el texto de las leyes eclesiásticas como su "ratio" y sus relaciones se expongan científicamente» (art. 55 Ord.), texto que no ha sufrido modificación en el Decreto de la mencionada Congregación de 2 de septiembre de 2002, «quo ordo studiorum in Facultatibus Iuris Canonici innovatur» ${ }^{29}$.

\subsection{El método exegético y el método sistemático en la doctrina científica posterior al «Codex» de 1917}

Ante algunas valoraciones críticas -más o menos discutibles- sobre el «Codex», que se han ido abriendo paso a lo largo de los años, se ha puesto de relieve con razón que, con una técnica bastante depurada, el «Codex» «puso fin a la confusión legislativa precedente», «hizo posible un mejor conocimiento de las leyes eclesiásticas», «permitió un desenvolvimiento más ordenado de la vida eclesial», sin olvidarnos de que «también ha favorecido un notable desarrollo de los estudios canónicos, que a inicios del siglo XX se encontraban en una situación de decadencia ${ }^{30}$.

Las disposiciones aplicativas del «Codex» de los años 1917-1918 y, después, un contexto de absoluta prevalencia y centralidad del «Codex», condicionaron decisivamente el desarrollo de la Ciencia del Derecho canónico en los ambientes eclesiásticos: el método exegético fue preponderante. El desarrollo de la doctrina canónica de carácter exegético, era ya subrayado hace muchos años por De Echeverría con frase coloquial, pero enormemente gráfica: $\ll \mathrm{El}$ método exegético ha hecho furor» ${ }^{31}$. No parece necesario aquí dar cuenta detallada de los numerosos autores que siguen la orientación propia del estricto método exegético. En cualquier repertorio bibliográfico puede encontrarse su-

29 AAS 95 (2003) 281-285.

${ }^{30}$ G. Feliciani, «Codex Iuris Canonici...», cit., 171.

31 L. DE ECHEVERría, Exposición de conjunto de la actual bibliografía canónica, Vitoria 1955, 27 y en Scriptorium Victoriense 2 (1955) 182. 
ficiente información al respecto ${ }^{32}$. En cambio, parece útil reseñar brevemente las notas principales del método exegético que caracteriza a buena parte de la doctrina posterior al Código de 1917. Quizá se puedan reducir a estas cuatro ${ }^{33}$ : a) «el apegamiento al texto legal»; b) «la marginación respecto a los progresos de la ciencia jurídica general»; c) una «cierta confusión entre Teología Moral y Derecho canónico»; y d) la innegable preponderancia del método exegético, en la mayor parte de los autores, es más una prevalencia de la referencia continua al texto del Código -«schola textus»- que una exclusividad metodológica: hay que entender, interpretar, estudiar y sobre todo aplicar el «Codex» y para ello, hay que someterlo a exégesis, pero utilizando todas las indicaciones que el propio Código ofrece en materia de interpretación (cann. 17-20), con la ayuda de la historia y sobre la base de una buena cultura jurídica general ${ }^{34}$.

Frente a la corriente exegética, la dogmática jurídico-canónica italiana -compuesta por canonistas laicos italianos, profesores de las Facultades de Derecho- desarrollará el método sistemático en el estudio del Derecho canónico, dando lugar a brillantes construcciones, que no desmerecen, al menos en su aspecto jurídico-formal, de las similares construcciones realizadas por la Ciencia jurídica en general. Con razón ha podido decirse que el principal mérito de la dogmática italiana «radica en haber contribuido de manera decisiva a devolver al Derecho canónico la dignidad de una ciencia jurídica de primer orden ${ }^{35}$. A pesar de la lógica variedad de opiniones, natural en una actividad científica llena de vivacidad y en la que han sido frecuentes las polémicas doctrinales ${ }^{36}$, es posible señalar unas líneas fundamentales de la visión del Derecho canónico

${ }^{32}$ Vid., por ejemplo, V. DEL GIUDICE, Nozioni di diritto canonico, Milano ${ }^{12} 1970$, 6-8; P. ERDÖ, Introductio in historiam scientiae canonicae. Praenotanda ad Codicem, Roma 1990, 157-163 y G. MAY A. EGLER, Einfiibrung in die kirchenrechtliche Methode, Regensburg 1986, 93-99, cit. en C. REDAELLI, Il metodo esegetico applicato al Codice di Diritto Canonico del 1917 e a quello de 1983, Periodica 86 (1997) 57-100: 65.

33 Vid. J. Fornés, La ciencia canónica..., cit., 301-307.

34 C. ReDAeLLi, Il método esegetico..., cit., 69-70.

35 A. DE LA Hera, Introducción a la Ciencia del Derecho Canónico, Madrid 1967, 124. Se apoyó también esa recuperación en el convencimiento de que el ordenamiento jurídico no debe limitarse al ordenamiento estatal y que puede haber otros ordenamientos jurídicos a todos los efectos: S. Romano ya en 1918 al defender la posible pluralidad de ordenamientos ponía como ejemplo el ordenamiento canónico, calificándolo de primario (S. Romano, L'ordinamento giuridico, Pisa 1918, 115-116).

36 Sobre la variedad y riqueza de la diversidad en la llamada «Escuela laica italiana», vid. S. BERLINGÒ, Il concetto di Diritto Canonico nella scuola laica italiana, en Il Concetto di Diritto Canonico. Storia e prospettive, a cargo de C. J. ERrázuriz M. - L. NAVArRo, Milano 2000, 47-69. Contrario a la calificación de «Escuelas canonísticas» se ha manifestado, hace algunos años, R. TORFs, Les écoles canoniques, Revue de Droit Canonique 47 (1997) 89-110: 97. 
característica de esta orientación doctrinal ${ }^{37}$ : a) la estrecha conexión de la dogmática jurídico-canónica italiana con la doctrina jurídica general; b) su actitud ante el «Codex Iuris Canonici» de 1917 o ante el dato normativo en general: le preocupa $-\mathrm{y}$ valora- - el estudio del conjunto, las instituciones jurídicas, las nociones técnicas finamente elaboradas por la cultura jurídica y decantadas en figuras sin aristas ni fisuras: la "construcción del sistema", en suma» ${ }^{38}$; c) el esfuerzo por deslindar ámbitos científicos y consiguientemente por establecer una absoluta y total pureza metódica, que lleva casi necesariamentea un cierto formalismo jurídico y a una desconexión de lo jurídico de sus auténticas bases de fundamentación; y d) los cultivadores del método sistemático no consideran la Codificación de 1917 -con todas sus consecuencias, como la aplicación del método exegético- como una verdadera innovación: parece que la verdadera innovación, en cambio, es la recepción por su parte de la Dogmática jurídica italiana también en el ámbito canónico ${ }^{39}$. Conviene observar que este método, si bien se diferencia de la corriente exegética, sin embargo tiene en común con ella la concepción positivista del Derecho. El Derecho es sólo el vigente y éste se identifica con las leyes dadas por el legislador, en nuestro caso, principalmente el «Codex» de $1917^{40}$. Se ha resaltado también que «D'Avack ha hablado, al referirse a las elaboraciones de la canonística italiana laica, "de nuestra doctrina positivista" $\gg^{41}$. Volvemos a encontrarnos con la centralidad y prevalencia de la ley y del legislador.

Todo este planteamiento científico condujo a la Ciencia del Derecho canónico a una altura muy estimable y a un respeto y prestigio considerables en todos los ámbitos científicos. Cierto es que esto se refiere fundamentalmente a Italia; pero el ejemplo de Italia tiene siempre una gran influencia, y sobre todo en un periodo histórico en que la Ciencia jurídica italiana recobró en buena parte el prestigio que en tiempos antiguos disfrutó en el mundo del Derecho. Por lo que se refiere a la canonística fuera de Italia, España ha sido el país donde el influjo de la dogmática jurídico-canónica italiana ha sido más intenso: de José Maldonado proviene la orientación científica de gran atención a los maestros

37 Vid. J. ForNÉs, La ciencia canónica..., cit., 307-317.

${ }^{38}$ Ibid., 312-313.

39 O. GIACCHI, Diritto canonico e dogmatica giuridica moderna, Il Foro italiano 64 (1939) 161-187.

40 «É questo diritto che va spiegato minuciosamente, così afferma la scuola esegetica, o che va utilizzato per ricavare i principi generali di un sistema logico, così pensa la scuola dogmatica» (C. REDAELLI, Il metodo esegetico..., cit., 74).

${ }^{41}$ J. Hervada - P. Lombardía, El Derecho del Pueblo de Dios..., cit., 211. 
italianos asumida por determinados jóvenes profesores universitarios, especialmente Alberto Bernárdez y Pedro Lombardía. «Sin embargo, esta influencia -como ha subrayado el propio Maldonado- no ha sido una mera repetición, sino, en muchos casos, una verdadera revisión de ideas y construcciones» ${ }^{42}$.

\subsection{Posibilidad de aplicación al Derecho de la Iglesia de los esquemas y métodos de la moderna Ciencia jurídica}

La Dogmática jurídico-canónica italiana, con diversos matices, progresó por los derroteros de la moderna Ciencia jurídica para la construcción sistemática del Derecho canónico. La cuestión acerca de la oportunidad o la posibilidad de aplicar al Derecho canónico el método propio de la Ciencia jurídica secular, fue el núcleo central, junto a otros aspectos de menor entidad, de la conocida polémica de los años 40 y 50 en Italia, que dio lugar a una abundantísima literatura y ha sido muy tratada por la doctrina ${ }^{43}$. La polémica se sitúa en torno al tema de las características fundamentales del Derecho canónico, Derecho que, teniendo en cuenta el fin de la Iglesia, constituye una experiencia singular en el mundo del Derecho en general. La polémica tiene su origen inmediato en la publicación en 1941 del muy citado y discutido «Discorso generale sull'ordinamento canonico» de Pio Fedele ${ }^{44}$. El núcleo de su doctrina ha sido eficazmente resumido del modo siguiente: «Para este autor todas las normas canónicas responden a la necesidad de lograr la salvación de las almas $\mathrm{y}$, consiguientemente, a evitar el pecado o el peligro del pecado y esto de un modo tan directo y exclusivo que puede considerarse su único fin» ${ }^{45}$.

Una de las consecuencias fundamentales de la doctrina de Fedele es que en el ordenamiento canónico «no se da la posibilidad de ejercer un derecho cuando esa posibilidad lleve consigo un pecado o un peligro de pecado» ${ }^{46}$. Los puntos de vista de Fedele fueron objeto de revisión por parte de casi toda la canonística italiana. No es necesario relatar aquí -sería un cometido muy prolijo- la

\footnotetext{
42 Ibid., 212.

43 Vid., por ejemplo, P. LOMBARDía, Sobre las características peculiares del ordenamiento canónico [Temis 5 (1959) 67-94], en IDEM, Escritos de Derecho Canónico, vol. I, Pamplona 1973, 177-191; IDEM, El Derecho canónico en las Facultades de Derecho [Ius Canonicum 1 (1961) 177-213], en IDEM, Escritos..., vol. I, cit., 288-306; y G. FELICIANI, La scuola canonistica italiana dal dogmatismo giuridico al post-concilio, en Scienza giuridica e diritto canonico, Torino 1991, 61-80.

44 P. FEDELE, Discorso generale sull'ordinamento canonico, Padova 1941.

45 P. LOMBARDíA, Sobre las características..., cit., 180.

46 P. Fedele, Discorso generale..., cit., 24.
} 
historia de la polémica; pero sí es preciso decir que en 1950 se celebró un Congreso Internacional de Derecho canónico en Roma sobre «El derecho subjetivo y su protección en el Derecho canónico» ${ }^{47}$. A partir de dicho Congreso, Fedele va desarrollando sus puntos de vista para llegar a concluir que en el Derecho canónico no existen derechos subjetivos ni, consiguientemente, acciones de tute$1 \mathrm{l}^{48}$. Contra tal tesis negativa, se manifestó la práctica totalidad de la doctrina científica italiana que participó en la polémica ${ }^{49}$ : unos autores se centraron en afirmar su existencia mostrando en el «Codex» diversos supuestos de derechos subjetivos; otros, afirmaron su existencia a partir de un planteamiento general diferente al de Fedele, como en el caso de Ciprotti ${ }^{50}$ Olivero $^{51}$ y De Luca ${ }^{52}$.

Guarda una lógica relación con la polémica sobre el derecho subjetivo toda la cuestión doctrinal en torno al sentido y consecuencias jurídicas del canon 87 del «Codex Iuris Canonici» de 1917: con este canon aparece por primera vez en el Derecho canónico un texto acerca de la persona física como sujeto capaz de realizar actos con relevancia jurídica en el ordenamiento; doctrina elaborada por la ciencia jurídica secular. En el canon 87 se lee: «Por el bautismo el hombre es constituido persona en la Iglesia de Cristo con todos los derechos y obligaciones de los cristianos [...]». Según la inmensa mayoría de los autores $^{53}$, tanto de los comentadores del «Codex» que emplean el método exegético como de los pertenecientes a la Dogmática jurídico-canónica italiana, el

${ }^{47}$ Acta Congressus Internationalis Iuris Canonici (Romae, in aedibus Pont. Universitatis Gregorianae 2530 septembris 1950), Romae 1953, 244 pp.

$48 \ll$ Se è vero che lá dove il momento pubblicistico ha il sopravvento su quello privatistico fin quasi a soppiantarlo del tutto ed a renderlo lettera morta, ivi non è atmosfera respirabile per il diritto soggettivo e per la sua tutela, e se è vero che nell'ordinamento canonico il momento pubblicistico è di gran lunga dominante rispetto a quello privatistico, si deve concludere che nell'ordinamento canonico o non vi è posto per il diritto soggettivo e per la sua tutela o questo posto è estremamente esiguo» (P. FEDELE, Il problema del diritto soggettivo e dell'azione in relazione al problema della distinzione tra diritto pubblico e diritto privato nell'ordinamento canonico, en Acta Congressus..., cit., 116). Años más tarde, afirma claramente que «il diritto soggettivo, in quanto collegato a un interesse del singolo, sia lettera morta nell'ordinamento canonico; nel quale, in sostanza, non esiste alcun diritto soggettivo privato, in quanto non esiste una vera e propria tutela dell'interesse individuale» (P. FEDELE, Lo spirito del diritto canonico, Padova 1962, 863).

49 Vid. una síntesis eficaz de la polémica sobre los derechos subjetivos en P. J. VILADrich, Teoría de los derechos fundamentales del fiel. Presupuestos críticos, Pamplona 1969, 32-68.

50 P. CiprotTi, Considerazioni sul «Discorso generale sull'ordinamento canonico» di Pio Fedele, Firenze 1941; IdeM, Lezioni di Diritto Canonico, Padova 1943, 123-131; IDEM, De vocabulorum usu ad ius subiectivum designandum in Codice Iuris Canonici, en Acta Congressus..., cit., 57-61.

51 G. OLIVERO, Intorno al problema del diritto soggettivo nell'ordinamento canonico, Torino 1948.

${ }_{52}$ L. DE LUCA, I diritti fundamentali dell'uomo nell'ordinamento canonico, en Acta Congressus..., cit., 88-103.

${ }^{53}$ Puede verse un elenco de estos autores en P. J. VILADRICH, Teoría de los derechos..., cit., 72-75. 
canon 87 solamente reconoce como personas en la Iglesia a los que han recibido el sacramento del bautismo y considera a los demás sujetos no bautizados como desprovistos de personalidad. Los más brillantes de estos autores incluso afirman que ese canon canoniza un principio de Derecho divino ${ }^{54}$. Para estos autores está totalmente identificado el momento en que se adquiere en Derecho canónico la condición de persona con la elevación al orden de la gracia que produce el bautismo; incluso no han faltado autores que atribuyen al sacramento del bautismo dos clases de efectos: los de orden teológico y los de carácter jurídico, o sea la adquisición de la personalidad ${ }^{55}$. Todos coinciden en afirmar que la persona es el sujeto de derechos y deberes, acogiendo, para explicar la situación jurídica del bautizado en el Derecho de la Iglesia, el concepto de persona dominante en la doctrina positivista del Derecho civil secular. Algún autor que, en la polémica mencionada sobre los derechos subjetivos, había afirmado -frente a Fedele- su existencia en el Derecho canónico al comprobar que en el «Codex» había múltiples supuestos de derechos subjetivos, incluso algunos atribuidos a los no bautizados, ahora ante el absurdo de afirmar estos derechos sin reconocer la existencia de una persona física sujeto de ellos, disiente de la doctrina casi unánime que niega la condición jurídica de persona al no bautizado: entre los comentaristas, se puede mencionar a Bender ${ }^{56}$ y entre los autores de la dogmática jurídica, a Ciprotti ${ }^{57}$, Gismondi ${ }^{58}$ y Olivero ${ }^{59}$.

54 «[...] hoc quidem non ex Ecclesiae statuto sed ex voluntate divina ipsius Ecclesiae Fundatoris» (G. Michiels, Principia generalia de personis in Ecclesia, Parisiis-Tornaci-Roma ${ }^{2} 1955,13-14$ ).

${ }_{55}$ M. Conte a Coronata, Institutiones Iuris Canonici, vol. I, Taurini ${ }^{4} 1950,131$.

56 Bender dirige el discurso hacia consideraciones filosóficas: por la misma naturaleza de las cosas no hay hombres no capaces jurídicamente y por naturaleza el hombre es persona también en sentido jurídico; consiguientemente abandona y critica la formulación del canon 87: el legislador debería haber hablado de «membrum Ecclesiae» constituido por el bautismo, no de «persona in Ecclesia» (L. BENDER, Normae generales de personis. Commentarius in canones 87-106, Roma-Parigi-New YorkTournai 1957, 4-16; IDEM, Persona in Ecclesia-Membrum Ecclesiae, Apollinaris 32 (1959) 105-119).

57 Ciprotti llama la atención sobre las facultades que el «Codex» reconoce a los no bautizados (por ejemplo, el canon $742 \$ 1$ acerca del bautismo que en caso de necesidad puede ser administrado por cualquier hombre o mujer incluso no bautizados y otros casos) que sólo pueden entenderse si se admite que éstos son personas para el Derecho canónico. El canon 87 ha de entenderse no en el sentido de que los no bautizados no sean «personas», sino que no lo son «in Ecclesia», pero sí son «personas» «extra Ecclesiam» (P. CIPROTTI, Personalità e battesimo nel diritto della Chiesa, Il diritto ecclesiastico 53 (1942) 273-276).

${ }^{58}$ Gismondi establece un paralelismo entre la posición del no bautizado en el Derecho canónico y la del extranjero en los ordenamientos civiles, es decir, personas jurídicamente capaces aunque carezcan de la condición necesaria para disfrutar de todos los derechos (P. GISMONDI, Gli acattolici nel diritto della Chiesa, Ephemerides iuris canonici 2 (1946) 224-249: 245-248).

59 Olivero, aunque parece admitir la doctrina casi unánime en la interpretación del canon 87 de que sólo los bautizados tiene personalidad (G. Olivero, Intorno al problema..., cit., 60), sin embargo 
Las doctrinas mayoritarias en la interpretación del «Codex Iuris Canonici» de 1917 acerca de sus prescripciones sobre la persona y sus derechos en la Iglesia son sin duda deficiencias e insuficiencias de la Ciencia jurídico-canónica -tanto la de carácter exegético como la de carácter sistemático- que no pueden achacarse sin más a la obra de la Codificación, aunque es verdad que ésta, reconduciendo la personalidad a esquemas formales, ha tenido una no pequeña responsabilidad al conducir a la doctrina, embebida de ideas positivistas, hacia soluciones no satisfactorias ${ }^{60}$. Porque es necesario repetir una vez más que, en la óptica de la Codificación, el Derecho se construye como un sistema racional por la voluntad de la autoridad; y esta voluntad y la ley que es su expresión, se colocan en el centro de la experiencia jurídica y constituyen la fuente primigenia del Derecho y el punto de referencia último de la conceptualización jurídica ${ }^{61}$. La centralidad y prioridad de la ley y de su autor -el legislador-, conducen a la idea de que la personalidad y sus derechos son atribuciones de la ley, ley que es propiamente su fuente. Se ha dicho que ese positivismo de fondo es un positivismo «ingenuo», «candoroso» que no niega la trascendencia ni la realidad metafísica y sustancial de la persona humana que es objeto de reflexión filosófica y teológica; es un entender el Derecho canónico como el texto de las leyes positivas -principalmente el «Codex»- promulgado por el legislador; y entenderlo en clave exegética cerrada: esta reducción del Derecho al tenor literal de la ley es una herencia que llega con fuerza hasta nuestros días ${ }^{62}$.

\section{El primado de la persona en el Derecho del Pueblo de Dios}

\subsection{Hacia una concepción integradora de la Ciencia del Derecho canónico en las vísperas del Concilio Vaticano II}

Sin prisa pero sin pausa, los muros de mutua desconfianza que durante varios lustros han separado a los canonistas de curia y a los canonistas laicos, se han ido abatiendo por obra de un buen grupo de canonistas laicos italianos.

\footnotetext{
manifiesta una posición análoga a la de Gismondi: «La Chiesa tende, per la sua istituzione, ad irradiare e diffondere i valori e i principi giuridici di cui è depositaria anche al di fuori della sua giurisdizione, e farne partecipe anche chi non ha la citadinanza cristiana» (G. OLIVERO, Diritto naturale e diritto della Chiesa, Il diritto ecclesiastico 61 (1950) 1-41: 41).

${ }^{60}$ G. Lo Castro, Il Mistero del Diritto. II. Persona e Diritto nella Chiesa, Torino 2011, 105.

${ }^{61}$ Ibid., 103.

62 J. OTADUY, Positivismos ingenuos. A propósito del discurso de Benedicto XVI sobre interpretación de la ley canónica (21-I-2012), Ius Canonicum 54 (2014) 23-44: 41-42.
} 
De esa intercomunicación de las dos grandes corrientes canonísticas de la primera mitad del siglo pasado se esperaban en esta época histórica buenos y eficaces resultados, en la medida en que los cultivadores de la exégesis se abriesen a una técnica más depurada y a la superior concepción del Derecho que los otros poseen; y los canonistas de la dogmática jurídica se conformasen más en sus construcciones a las exigencias del espíritu de la Iglesia y a los fundamentos puestos por la Teología y la Filosofía tradicionales.

A este respecto es interesante hacer especial mención aquí a los primeros años de actividad docente y científica, de Pedro Lombardía (1930-1986) ${ }^{63}$, durante la plena y efectiva vigencia del «Codex Iuris Canonici» de 1917, en las vísperas del Concilio Vaticano II y en los inicios de la segunda Codificación. Y no solamente porque ha sido maestro de muchos de los profesores de la Facultad de Derecho Canónico de la Universidad de Navarra, sino sobre todo porque la bibliografía actual ${ }^{64}$-a los treinta años de su prematura muerte en 1986- lo considera unánimemente como cabeza y maestro de una de las más conocidas y prestigiosas corrientes científicas de la canonística contemporánea.

Pedro Lombardía estudia Derecho en la Universidad de Granada. Su profesor de Derecho canónico fue un sacerdote de la más tradicional escuela exegética. Se traslada a Roma en 1949 y allí permanece hasta 1952. En este periodo romano, cursa estudios de Derecho canónico en el entonces Pontificio Instituto Internacional «Angelicum» de Roma, donde obtiene el grado de doctor en 1952, incorporándose seguidamente como profesor de Derecho canónico a la Facultad de Derecho del recién erigido Estudio General de Navarra -germen de la futura Universidad-, donde empieza su andadura en 1959 la Facultad de Derecho Canónico. Alumno de Granada y Doctor por el «Angelicum» podría esperarse que llegase a su nueva universidad formando parte de la corriente exegética: la conocía bien y a fondo y apreció siempre su honestidad intelectual. Pero Lombardía tenía otras preferencias y otros planes. Durante su

${ }^{63}$ Sobre Pedro Lombardía, vid., entre otros, R. NAVARro-VAlls, La figura de Pedro Lombardía, Anuario de Derecho Eclesiástico del Estado 3 (1987) 17-25; J. MARTínEZ-TORRón - A. DE LA Hera, Pedro Lombardía. A los treinta años de su muerte, Ius Canonicum 56 (2016) 487-512.

${ }^{64}$ Entre otros, C. Fantappiè, Eclesiologia ..., cit., 106-107, 277-280, 288-291, 331-336; C. HerreRA PARDO, Aproximación a los fundamentos científicos y filosóficos del iusnaturalismo realista de Favier Hervada, Capítulo II: La Escuela de Lombardía y su aportación crítica a la canonistica del siglo XX, Pamplona 2016, 95-216; I. C. Iban, Derecho Canónico y Ciencia Furídica, Madrid 1984, 275-285, 467-469; C. REDAELLI, Il concetto di diritto della Chiesa nella riflessione canonistica tra Concilio e Codice, Milano 1991, 163-252; IDEM, Il metodo esegetico..., cit., 80, 84-87. 
estancia en Roma, no se limitó a frecuentar las aulas del «Angelicum» sino que asistió a las clases de Derecho canónico impartidas por Vincenzo del Giudice en la Universidad «La Sapienza» de Roma. Entra así en contacto con la corriente de renovación metodológica de la dogmática jurídico-canónica italiana, alineándose con esa corriente científica, como discípulo de Del Giudice, con el claro objetivo de propiciar una revitalización del Derecho canónico a través de una renovación metodológica. Se ha podido afirmar que el encuentro de Lombardía con Del Giudice es «uno de los grandes momentos de la historia de la ciencia canonística en este siglo» $[\text { siglo } \mathrm{XX}]^{65}$. Lombardía buen conocedor de la corriente exegética, incorporó a sus conocimientos los de la dogmática laica italiana, comprendiendo las virtualidades de ambas corrientes ${ }^{66}$. Lombardía fue consciente desde muy pronto de la necesidad de buscar un camino nuevo, adecuado a los nuevos tiempos de la Ciencia del Derecho canónico, que superase la dicotomía que aislaba a ambas corrientes: su punto de partida es ciertamente la dogmática jurídica italiana -y concretamente la representada por Del Giudice-, pero intentando integrar las virtualidades positivas de la canonística exegética ${ }^{67}$. Introduce en España la doctrina de Del Giudice, traduciendo su

${ }^{65}$ A. DE LA Hera, Dos maestros de la ciencia canónica de la segunda mitad del siglo XX - Perfil bumano y personalidad científica de Pedro Lombardía y Eugenio Corecco, en Metodi, fonti e soggetti del Diritto Canonico, a cargo de J. I. Arrieta - G. P. Milano, Città del Vaticano 1999, 19-31: 24.

${ }^{66}$ Desde la perspectiva de la actitud ante el dato legal, se percibían en esta época los contrastes entre el planteamiento metodológico de la exégesis dedicada a la interpretación del dato legal y el de la dogmática jurídica dedicada a la construcción del sistema. Era necesario combinar adecuadamente el rigor exegético y la brillante construcción sistemática; la prudencia jurídica que acierta en la solución de los casos y la técnica que acierta en la fijación de las figuras jurídicas y en su adecuada colocación dentro del conjunto del sistema jurídico; el aspecto material, realista, y la elaboración formal, conceptual; en una palabra, la exégesis y el sistema habrían de complementarse y enriquecerse mutuamente. El único método que hay que seguir no es el sistemático, prescindiendo completamente del método exegético: un planteamiento de este tipo estaría irremediablemente destinado al fracaso. La exégesis sin sistema conduce, como es patente, al casuismo, a la minucia, a la dispersión de datos legales; el sistema sin exégesis conduce o puede conducir a la generalización teórica, al abstraccionismo, al logicismo formalista e inoperante. De ahí que resulte completamente necesaria la armónica conjunción de la exégesis con el sistema y el sistema con la exégesis (J. FoRNÉs, La ciencia canónica..., cit., 313).

${ }^{67} \mathrm{Ibid}$. En estos años, hablaba Lombardía de los excesos -a veces también verbales- de la dogmática italiana rechazando y criticando la corriente exegética, en contraste con los muchos aciertos que en el ámbito de la «prudentia iuris»-no hay que olvidar que el Derecho es Ciencia práctica- había tenido y seguía teniendo la -en no pocas ocasiones- menospreciada corriente exegética tradicional (P. LOMBARDía, Sobre la enseñanza universitaria y el método de estudio del Derecho Canónico [Revista española de Derecho Canónico 12 (1957) 165-173], en IDEM, Escritos..., vol. I, cit., 95-111; IDEM, Observaciones sobre el método en el estudio del matrimonio canónico [publicado como Prólogo a J. HERVADA, Los fines del matrimonio. Su relevancia en la estructura jurídica matrimonial, Pamplona 1960], en IDEM, Escritos..., vol. I, cit., 255-278). 
manual en $1955^{68}$. En 1956 defiende la tesis doctoral en la Facultad de Derecho de la Universidad Central de Madrid sobre la persona física en el ordenamiento canónico, siguiendo a su maestro Del Giudice y su teoría de la «canonizatio» ${ }^{69}$. La publicación de esta tesis que llegó a estar anunciada no se realizó en aquel momento ${ }^{70}$ porque Lombardía, en sus conversaciones con su principal discípulo y estrecho colaborador, Javier Hervada ${ }^{71}$, se dio cuenta muy pronto de que, al utilizar sin más la metodología de la dogmática jurídica italiana, aceptaba un trasfondo positivista, incongruente con el Derecho canónico: la solución de Del Giudice con su teoría de la «canonizatio» que había utilizado Lombardía para tratar de la persona física era ingeniosa pero insuficiente; se necesitaba perfeccionar el método de la dogmática italiana para que asumiese el Derecho natural y el Derecho divino positivo como verdaderos y propios Derechos, de modo directo y no por intervención del humano legislador ${ }^{72}$.

${ }^{68}$ V. Del GiUdice, Nociones de Derecho Canónico, Pamplona 1955.

${ }^{69}$ Las relaciones entre Derecho divino y Derecho humano -distinción que a la dogmática italiana le venía dada por las normas canónicas vigentes, el «Codex», y la tradición canónica- se resolvió por la mayoría de los cultivadores de la dogmática jurídica mediante el ingenioso expediente, propuesto por Del Giudice, de considerar al Derecho divino vigente en el ordenamiento de la Iglesia, en cuanto que «canonizado»; es decir, en cuanto que incorporado formalmente al ordenamiento por el legislador humano. Esta actitud de elaboración científica a partir de las normas positivas, sin crítica doctrinal previa, se considera un postulado de la dogmática jurídica.

70 Esta tesis doctoral fue publicada con carácter póstumo en 1989, P. LOMBARDía, Contribución a la teoría de la persona física en el ordenamiento canónico [Ius Canonicum 29 (1989) 11-106], en IDEM, Escritos..., vol. V, cit., 581-685.

${ }^{71}$ Javier Hervada Xiberta es reconocido como el principal discípulo y estrecho colaborador de Pedro Lombardía. Cuatro años más joven que el maestro, en 1954 conoció a Pedro Lombardía y desde 1957 colaboró estrechamente con él en el movimiento de renovación de la Ciencia canónica conocido como la Escuela de Lombardía. En estos primeros años de su actividad científica, en las vísperas de los inicios de la segunda Codificación, publicó varios importantes trabajos científicos, algunos de ellos con una actitud crítica de revisión y superación de las posiciones esenciales de la dogmática jurídico-canónica italiana: La impotencia del varón en el Derecho matrimonial canónico, Pamplona 1959; Los fines del matrimonio. Su relevancia en la estructura jurídica matrimonial, Pamplona 1960; El matrimonio in facto esse. Su estructura jurídica, Ius Canonicum 1 (1961) 135-175; Reflexiones acerca de la prudencia jurídica y el Derecho Canónico, Revista Española de Derecho Canónico 16 (1961) 415-451; Fin y características del Derecho Canónico (Notas en torno al tema), Ius Canonicum 2 (1962) 5-110; La relación de propiedad en el patrimonio eclesiástico, Ius Canonicum 2 (1962) 425-467; La ordinatio ad fines en el matrimonio canónico, Revista Española de Derecho Canónico 18 (1963) 439-499; El concepto de ordenamiento canónico en la doctrina contemporánea, Ius Canonicum 5 (1965) 5-61. Sobre la obra científica de Javier Hervada, pueden verse, entre otros, M. DEL Pozzo, L'evoluzione della nozione di diritto nel pensiero canonistico di favier Hervada, Roma 2005; J. EsCRIVÁ IVARS - J. HeRvada, Relectura de la obra científica de Favier Hervada, vols. I-III, Pamplona 2008-2009, en http://www.javierescriva.com/?p=172; C. HERRERA PARDO, Aproximación a los fundamentos..., cit.

72 Vid. al respecto, J. Hervada, Personalidad científica de Pedro Lombardía, Ius Canonicum 26 (1986) 491-496. 
Modernidad y superación del positivismo fueron los retos de esos primeros años de actividad canonística de Lombardía: estudiar el Derecho canónico no solamente como un ordenamiento jurídico abstracto sino como un adecuado instrumento al servicio de la misión de la Iglesia; abordar ese estudio según la propia naturaleza del Derecho canónico mediante el método sistemático; elaborar una ciencia de naturaleza jurídica mediante un método jurídico; ser canonista significa ser jurista. A la hora del trasplante de soluciones técnicas de la dogmática jurídica secular al Derecho canónico, se hacía necesario un planteamiento crítico, de modo que el trasplante no fuera automático e indiscriminado, sino adecuado a la naturaleza de la Iglesia y su Derecho ${ }^{73}$.

Ya en estos años, Lombardía cuestiona el papel central y casi único de la ley positiva -la centralidad de la ley- en el Derecho canónico, entendido éste como «complexus legum», contenido principalmente en el «Codex», «Código» que es el punto de partida tanto para la «interpretación» de los exégetas como para la «reconstrucción» de los dogmáticos. En cambio, en el pensamiento de Lombardía, desde el principio, la persona y su libertad ha ocupado el puesto principal y central -el primado- en el Derecho canónico ${ }^{74}$.

${ }^{73} \mathrm{Al}$ final de la primera parte de la memoria de su tesis doctoral de 1956, haciendo la crítica de la doctrina mayoritaria sobre la personalidad en el ordenamiento canónico elaborada por cultivadores de la dogmática jurídico-canónica italiana, declaraba: «la lectura de estos trabajos produce en el que está habituado a seguir de cerca los peculiarísimos aspectos de la vida jurídica de la Iglesia, la impresión de que les falta realismo. [...] Y es que en esta ocasión, como en tantas otras, al trasplantar al Derecho de la Iglesia las elaboraciones nacidas en torno al Derecho secular, no se ha tenido suficientemente en cuenta las peculiares características del ordenamiento canónico» (P. LOMBARDía, Contribución a la teoría..., cit., 645-646). A este argumento fundamental -al que volverá continuamente, de un modo u otro, a lo largo de toda su producción científica-, Lombardía dedica en 1959 un estudio titulado precisamente Sobre las características peculiares del ordenamiento canónico. El punto de partida de ese estudio consiste en precisar la calificación del ordenamiento de la Iglesia como ordenamiento jurídico: «La afirmación del carácter jurídico del ordenamiento canónico, sin duda exacta, y el acercamiento, desde tantos puntos de vista fecundo, de los estudios sobre el Derecho canónico y el de los Estados, encierra, sin embargo, un riesgo: que se pierda de vista la peculiar naturaleza del Derecho canónico». Ya al final del artículo, manifiesta que «las llamadas características peculiares del ordenamiento canónico [...], sólo pueden estudiarse con verdadera profundidad a la luz de la Teología» (P. LOMBARDía, Sobre las características peculiares..., cit., 177 y 221).

${ }^{74}$ A lo largo de su producción científica se ha ido consolidando ese carácter principal hasta poder afirmarse que, para Lombardía, la persona y su libertad ha sido y es el verdadero protagonista del ordenamiento canónico. Vid. sobre la persona y su libertad como hilo conductor del pensamiento canónico de Lombardía, V. GómEZ-IGLESIAS C., Libertad y Derecho Constitucional en Pedro Lombardía, Pamplona 1998. También sobre el pensamiento de Lombardía acerca de la persona en el ordenamiento canónico, remitimos a J. BERnAL, Temas fundamentales sobre el Derecho 
En junio de 1952, cuando todavía no había cumplido veintidós años de edad, Lombardía obtuvo el Doctorado en Derecho canónico en el «Angelicum» de Roma, defendiendo la tesis doctoral Los matrimonios mixtos en España hasta la caída de la monarquía visigoda, que dio lugar a tres primerísimas publicaciones ${ }^{75}$. Traemos a colación esta tesis y los artículos a que dio lugar, porque en ellos se estudia si la prestación del consentimiento conyugal dado por un no católico tiene validez jurídica para establecer un verdadero matrimonio, aflorando así la preocupación científica por la subjetividad canónica de la persona física no bautizada o infiel.

Se ha señalado antes cómo el tema de su tesis doctoral civil, defendida en noviembre de 1956, es precisamente la persona física en el ordenamiento canónico. El argumento central de dicha tesis es la crítica de la doctrina mayoritaria de los canonistas, tanto de los ateneos eclesiásticos como de los civiles, sobre la persona física, que apoyándose en el canon 87 del «Codex»-como hemos visto- niega a los no bautizados la personalidad ante el ordenamiento canónico. Para superar esa doctrina acude a la universalidad de la misión de la Iglesia -que llama a todos los hombres a formar parte de ella- y a otros cánones del «Codex» que atribuyen relevancia jurídica a determinados actos de los no bautizados o infieles. Partiendo del concepto de persona del civilista Federico de Castro $^{76}$, intenta elaborar una nueva teoría de la personalidad: «la per-

canónico y sus sujetos en los escritos de Pedro Lombardía, Fidelium Iura 6 (1996) 83-139; y acerca del Derecho y la libertad, vid. J. FoRNÉs, Derecho y libertad en el pensamiento de Pedro Lombardia, Ius Canonicum 74 (1997) 489-504.

75 P. LOMBARDía, Los matrimonios mixtos en la Iglesia cartaginesa del siglo III [ ${ }$ Cuadernos de Trabajos de Derecho», vol. II, Consejo Superior de Investigaciones Científicas, Delegación de Roma, Madrid 1953, 95-110], en IDEM, Escritos..., vol. I, cit., 51-72; IDEM, Los matrimonios mixtos en el Concilio de Elvira (a. 303?) (Notas para la historia del matrimonio canónico) [Anuario de Historia del Derecho Español 24 (1954) 543-558], en IDEM, Escritos..., vol. I, cit., 73-94; e IDEM, Los matrimonios mixtos en el Derecho de la Iglesia Visigoda [Anuario de Historia del Derecho Español 27-28 (1957-1958) 61-107], en IDEM, Escritos..., vol. I, cit., 113-172.

76 «La capacidad jurídica por muy abstracta y general que se conciba, no se puede identificar con la persona; la capacidad, es una manifestación -una de las más importantes, pero no la única- de las que tiene la persona en el Derecho. Ser persona no es sólo la posibilidad de tener derechos, es ser en el Derecho y tener sólo por ello, una situación jurídica, facultades, derechos y obligaciones» (F. DE Castro, Derecho Civil de España, Parte General, II-I, Madrid 1952, 23-24). La doctrina que elabora como algo indiscutible el concepto de personalidad basado en la idea de capacidad «incurre en un círculo vicioso: a la pregunta ¿quién es persona? Contesta: el capaz de derechos y obligaciones; a la pregunta ¿quién es capaz de derechos y obligaciones? Responde: la persona» (ibid., 29). «El camino aconsejable para definir la persona parece ser partir del concepto de persona humana y destacar su significado general en el Derecho, o sea, del reconocimiento de la situación jurídica que corresponde (dignitas) al hombre, a todo hombre, por su condición de ser racional, creado a imagen y semejanza del Creador» (ibid., 30). 
sonalidad es la concreción en el orden jurídico del ser ante la Iglesia y, en cierto sentido, en la Iglesia, de todo hombre» ${ }^{77}$.

La tesis que -como ya se ha dicho- no fue publicada entonces, debidamente remodelada dio lugar a varios artículos sobre la persona física, los infieles, los catecúmenos, y otros, que fueron viendo la luz en los años siguientes. En esos artículos, despojados de elementos anteriores de la dogmática jurídica italiana más pura -ya superados por él-, se recogía y desarrollaba la afirmación central de la tesis doctoral: toda persona física goza de personalidad jurídica ante el Derecho canónico.

En uno de esos artículos «Derecho divino y persona física en el ordenamiento canónico» (año 1960), Lombardía estudia los elementos de Derecho divino que fundamentan el estudio de la persona física en el ordenamiento canónico ${ }^{78}$. Desde estas nuevas bases, interpreta el canon 87 del «Codex» diciendo que, cuando habla de los «iura et officia christianorum», se refiere a «la titularidad efectiva de todos los derechos y obligaciones fundamentales que se derivan inmediatamente de la condición de cristiano», es decir, de bautizado, y añade que dicho canon no es otra cosa que «una solemne afirmación de los derechos y obligaciones fundamentales del cristiano» ${ }^{79}$. Se hace expresa mención aquí de este pasaje, porque parece que es la primera vez que se emplea en la doctrina la calificación de «derechos y deberes fundamentales» a los que derivan del bautismo y Lombardía lo hace contraponiéndolos en el mismo artículo a otros múltiples derechos y deberes del sujeto en el ordenamiento canónico ${ }^{80}$. Y por lo que respecta a las personas que no han recibido el bautismo, al final del artículo mencionado, hace una defensa de su libertad ante la ley

77 P. Lombardía, Contribución a la teoría..., cit., en IDEM, Escritos..., vol. V, cit., 680. «En el ordenamiento canónico, el sujeto, la persona, es el hombre; todo ser que tiene un alma que salvar. Esta personalidad se manifiesta en todas las facetas de la vida jurídica de la Iglesia. Siempre que el hombre es influido por las normas canónicas y siempre que las manifestaciones de su ser tienen una relevancia jurídica en el ámbito del ordenamiento. [...] La enumeración podría ser interminable; las circunstancias en que podría manifestarse, innumerables: siempre que el hombre sea término o sujeto de una relación -entendiendo esta palabra en su acepción más amplia- que se desarrolle en el ámbito del ordenamiento canónico» (ibid., 679).

78 P. Lombardía, Derecho divino y persona física en el ordenamiento canónico [Temis 7 (1960) 187-203], en IDEM, Escritos..., vol. I, cit., 223-253.

${ }^{79}$ Ibid., 236.

80 «Además de estos fundamentales aspectos de la situación jurídica de los sujetos, el Derecho canónico reconoce múltiples derechos y deberes que adquieren los sujetos como consecuencia de las vicisitudes de su vida jurídica. Los canonistas que siguen en este tema la opinión dominante, confunden la titularidad de los derechos fundamentales del cristiano con la capacidad de adquirir cualquier derecho o deber en el ámbito del ordenamiento» (ibid., 240). 
canónica ${ }^{81}$. Y a continuación se sitúa, con audacia poco común en esa época, ante los derechos calificados de fundamentales del no bautizado o infiel: «En alguna ocasión las normas canónicas deberán proteger -y de hecho lo hacenderechos fundamentales de los infieles» ${ }^{82}$.

En 1960 participa en la VIII ${ }^{a}$ Semana española de Derecho canónico (Universidad de Deusto-Bilbao) con una ponencia sobre la posible modificación de la sistemática del «Codex» de 1917. Lombardía hace la propuesta sistemática de tratar todo lo referente al Derecho canónico de la persona en el libro I o Parte general, con lo que, entre otras ventajas, «se conseguiría poner de relieve de una manera patente el espíritu eminentemente personalista del Derecho de la Iglesia» ${ }^{83}$. En 1962 participa en la IX Semana española de Derecho canónico (Universidad María Cristina de El Escorial) con una ponencia en la que trata directamente por primera vez del estatuto de las personas en el Derecho canónico ${ }^{84}$. En esta ponencia vuelve a hablar de los «derechos fundamentales del cristiano» adquiridos por «el hombre, mediante la recepción del bautismo»; pero avanza decididamente en su discurso científico calificando el «bautismo como acto jurídico generador del estado fundamental en el ordenamiento canónico»: la «condición jurídica de christifidelis» ${ }^{85}$. Y como yendo más allá, en profundidad, concluye: «Planteada la cuestión de los dere-

81 «Evidentemente los infieles no están obligados nunca a cumplir leyes eclesiásticas, por el mero hecho de serlo y de que las leyes hayan sido dictadas. Para ello es necesario, además, que se dé un acto jurídico que les coloque en la situación de destinatario concreto de la norma, y este acto, por lo que se refiere a las obligaciones, tiene que ser un acto de sometimiento voluntario [...]. Por lo que se refiere a los derechos, las normas canónicas, en su función de abrir cauces a relaciones sociales, pueden atribuir a los infieles facultades en orden al fin de la salvación de las almas; lo que en ningún caso podrán hacer es obligarles a ejercerlas» (ibid., 250-251).

$82 \mathrm{Ibid}$., 251. «Piénsese en el [derecho] de recibir el bautismo que sin duda el ordenamiento canónico reconoce y protege, frente a la posible negligencia del pastor de almas que en cada caso tenga la obligación de administrarlo» (ibid.).

83 P. LOMBARDía, La sistemática del Codex y su posible adaptación [en Teoría general de la adaptación del Código de Derecho Canónico (Trabajos de la VIII Semana Española de Derecho Canónico), Bilbao 1961, 213-237], en IDEM, Escritos..., vol. I, Pamplona 1973, 347-395: 392.

${ }^{84}$ P. Lombardía, El estatuto personal en el ordenamiento canónico. Fundamentos doctrinales [en Aspectos del Derecho Administrativo canónico (Actas de la IX Semana española de Derecho Canónico), Salamanca 1964, 51-66], en IDEM, Escritos de Derecho Canónico, vol. II, cit., 33-62.

85 Ibid., 37-38. «Es obvio que existen una serie de derechos y deberes canónicos que competen al hombre por el hecho de recibir el bautismo: son los "christianorum iura et officia" a que alude el c. 87. No es menos cierto, sin embargo, que otros muchos derechos y deberes que las normas canónicas regulan o conceden, no son comunes a todos los fieles; sino privativos de determinados grupos, que se caracterizan por vivir una específica vocación cuyo contenido es el cumplimiento de una determinada misión eclesial. Es el caso de los derechos y deberes peculiares de los clérigos, religiosos y laicos» (ibid.). 
chos y deberes de los fieles, de manera que se trascienda de la mecánica aplicación de las normas de Derecho positivo para penetrar en su "ratio", nos adentramos en el espíritu del ordenamiento de la Iglesia desde un ángulo de enfoque poco habitual entre los canonistas y muy importante: la consideración del hombre» ${ }^{86}$.

Así las cosas, Lombardía es consciente de que habría que esforzarse por encontrar o reafirmar unas bases más sólidas que las propias del positivismo jurídico más puro, que hunde sus raíces en presupuestos formalistas de raíz kantiana, para dirigir la mirada al realismo jurídico y al iusnaturalismo clásico; esto es, habría que introducir el factor de corrección propio de una fundamentación del Derecho canónico más acorde con su propia naturaleza. En 1960, la ponencia ya mencionada con la que participó en la VIII ${ }^{a}$ Semana española de Derecho canónico concluía con una referencia al espíritu de la sistemática propuesta para una eventual modificación del libro I del «Codex»: «En cuanto al espíritu del sistema [...], no parece que nos lo pueda dar un Código artificialmente orgánico, sino la fuerza del título sobre Dios legislador y el Derecho divino que creemos se debe introducir en el libro I ${ }^{87}$. Él será para la práctica canónica, garantía de rectitud y elasticidad, de justicia y equidad; y, para la ciencia, el camino que lleve al jurista a la consideración de la sobrenaturalidad del ordenamiento de la Iglesia y dirija a la canonística de nuestra generación hacia una doctrina jurídica, fundada en la Filosofía y en la Teología tradicional, que pueda ofrecer a los cultivadores del Derecho secular, soluciones técnicas eficaces, para salvar la crisis del Derecho que nos ha legado el positivismo jurídico» ${ }^{88}$. Un año antes, en 1959 , concluía su artículo sobre las peculiares características del Derecho de la Iglesia, diciendo de modo casi programático: «Los canonistas descubrieron hace lustros la fecundidad de hacer llegar al Derecho de la Iglesia las ventajas científicas de la doctrina jurídica moderna. De ello se siguieron innegables ventajas. Ahora es el momento de

86 Ibid., 40.

87 Proponía Lombardía, inspirándose en el título de las Decretales De Summa Trinitate et Catholica Fide, pero dándole una mayor proyección jurídica, encabezar el libro I del «Codex» con un título breve y claro sobre el Derecho divino: De Deo legislatore et de iure divino (P. LOMBARDÍA, La sistemática del Codex..., cit., 354-357, 392 y 395).

$88 \mathrm{Ibid}$, 395. «Las ideas sobre los fundamentos del Derecho elaboradas por la Filosofía y la Teología escolástica influyen demasiado poco en la doctrina, incluso en la de corte más tradicional, lo cual ha ocasionado en unos casos un empobrecimiento de las elaboraciones de carácter general y en otros unas construcciones teóricas influidas por el positivismo jurídico, tan brillantes como poco coherentes con el espíritu del ordenamiento de la Iglesia» (ibid., 357-358). 
que descubran también sus limitaciones y se encaminen hacia un estudio de los problemas canónicos profundamente enraizado en la Teología. Solamente de este modo podremos saber qué es de verdad el Derecho canónico y la profunda raíz de sus instituciones; así se podrá conocer también con más profundidad en qué se diferencia de los ordenamientos seculares» ${ }^{89}$.

Esta concepción integradora del Derecho canónico propuesta por Pedro Lombardía en las vísperas del Concilio Ecuménico Vaticano II, tiene -como hemos visto- su núcleo primordial en el paso de la centralidad de la ley al primado de la persona y sus derechos en el ordenamiento canónico, paso al que contribuye de manera determinante.

\subsection{El nuevo Derecho canónico: un orden de libertad}

El Concilio Ecuménico Vaticano II (1962-1965) supuso una profunda reflexión de la Iglesia sobre sí misma ${ }^{90}$ y por tanto constituyó un acontecimiento fundamental para el Derecho canónico: sus documentos fueron llamados a desempeñar el papel de fermento de una Ciencia canónica renovada y de base y fundamento de la llamada segunda Codificación que inició sus trabajos cuando el Concilio estaba para terminar.

El Capítulo II de la Constitución sobre la Iglesia, «Lumen gentium», que lleva por título «De Populo Dei» y que precede sistemáticamente al Capítulo III acerca de la constitución jerárquica de la Iglesia, enseña solemnemente que este Pueblo de Dios tiene por cabeza a Cristo, tiene por condición la dignidad y libertad de los hijos de Dios, tiene por ley el mandato nuevo del amor y su fin es la progresiva dilatación del Reino de Dios, incoada por Cristo en la tierra ${ }^{91}$. Este Pueblo de Dios elegido es uno; es común la dignidad de sus miembros, común la gracia de hijos, común la llamada a la perfección y entre todos rige una verdadera igualdad en cuanto a la dignidad y a la acción común a todos los fieles en orden a la edificación del cuerpo de Cristo ${ }^{92}$. Pero la

${ }^{89}$ P. LOMBARDÍA, Sobre las características peculiares..., cit., 222. Años más tarde, en 1968, Lombardía escribirá: «Sin una vigorosa fundamentación eclesiológica no será posible que los canonistas capten las peculiares características de la comunidad eclesial, las cuales exigen necesariamente unas soluciones jurídicas también peculiares, coherentes con las exigencias de la constitución divina del Pueblo de Dios» (P. LOMbardía, El Derecho en el actual momento de la vida de la Iglesia [Palabra 33 (mayo 1968) 8-12], en IDEM, Escritos..., vol. II, cit., 433-455: 440).

90 PABLO VI, Enc. Ecclesiam suam, 6-VIII-1964, AAS 56 (1964) 609-659: 611.

91 Conc. VAT. II, Const. Lumen gentium, 21-XI-1964, n. 9.

92 Ibid., n. 32. 
Iglesia no sólo ha reflexionado sobre sí misma, sino también sobre su relación con el mundo, concretamente en la Constitución sobre la Iglesia en el mundo actual, «Gaudium et spes». En ella se encuentra consagrada la que podría denominarse dimensión personalista y comunitaria del hombre. El Capítulo I de su Parte primera, «De humanae personae dignitate» y el Capítulo II, «De hominum communitate», enseñan que el hombre es el centro y culmen de la creación y que todo lo que hay en la tierra está a él ordenado ${ }^{93}$; el hombre ha sido creado a imagen de Dios y en esto se basa su dignidad ${ }^{94}$; goza de una verdadera libertad, signo eminente de la imagen divina en el hombre ${ }^{95}$; y ha de ser reconocida cada vez más la igualdad fundamental entre todos los hombres ${ }^{96}$. Esta dimensión personalista tiene primacía sobre la comunitaria porque «el principio, el sujeto y el fin de todas las instituciones sociales es y debe ser la persona humana, la cual por su misma naturaleza tiene completa necesidad de la vida social» ${ }^{97}$, también porque el orden social debe subordinarse al bien de las personas ${ }^{98}$ y consiguientemente todas las instituciones privadas $o$ públicas se deben esforzar por ponerse al servicio de la dignidad y del fin del hombre ${ }^{99}$. Acerca de la persona humana y su libertad, se pronuncia también la Declaración sobre la libertad religiosa «Dignitatis humanae» cuando dice que en cualquier caso «se debe observar la costumbre de una completa libertad en la sociedad, según la cual debe reconocerse al hombre el máximo de libertad y no debe restringirse sino cuando y en la medida que sea necesario» ${ }^{100}$. Como la gracia no suprime la naturaleza sino que la eleva y perfecciona, todas estas enseñanzas conciliares acerca de la persona y la sociedad son aplicables a las personas bautizadas y a la comunión de los fieles. También en la Iglesia se manifiestan, a su modo, las dimensiones personalista y comunitaria ${ }^{101}$.

${ }^{93}$ Conc. VAT. II, Const. Gaudium et spes, 7-XII-1965, n. 12.

${ }^{94}$ Ibid., nn. 12-16.

95 Ibid., n. 17.

96 «Cum omnes homines, anima rationali pollentes et ad imaginem Dei creati, eamdem naturam eamdemque originem habeant, cumque, a Christo redempti, eadem vocatione et destinatione divina fruantur, fundamentalis aequalitas inter omnes magis magisque agnoscenda est» (ibid., n. 29).

97 Ibid., n. 25.

98 Ibid., n. 26.

99 Ibid., n. 29.

100 «Ceterum servanda est integrae libertatis consuetudo in societate, secundum quam libertas debet quam maxime homini agnosci, nec restringenda est nisi quando et prout est necessarium» (Conc. VAT. II, Declar. Dignitatis bumanae, 7-XII-1965, n. 7).

101 E. Molano, La autonomía privada en el ordenamiento canónico, Pamplona 1974, 34-36. 
Principios centrales en el magisterio conciliar -la llamada universal a la santidad; la santificación de los laicos en medio del mundo y de los quehaceres temporales; la libertad y responsabilidad de los cristianos en la Iglesia y en el mundo; el carácter de servicio o diaconía del ministerio eclesiástico; los carismas en la edificación de la Iglesia- significaron para Pedro Lombardía la confirmación por parte del Concilio Vaticano II de lo que -junto con otros miles de personas de toda condición- desde tantos años antes, en el Opus Dei, había leído, oído y aprendido a vivir de San Josemaría Escrivá de Balaguer ${ }^{102}$. Lombardía, consecuente con sus planteamientos acerca del Derecho divino, madurados -como ya hemos visto- en torno a los años 1958-1959, supo ver también en esos principios doctrinales del Concilio Vaticano II sus implicaciones canónicas; y, concretamente, en algunos casos, su carácter de elementos de Derecho divino, que requerían una técnica jurídica adecuada para su formalización, de modo que se lograse una más eficaz vigencia histórica en el Pueblo de Dios y se hiciese posible un nuevo Derecho canónico. Supo contagiar esas nobles ambiciones científicas a muchos colegas y discípulos de la Universidad de Navarra. En esa tarea contaron siempre con el aliento y estímulo de su Gran Canciller: entre esos impulsos hay que mencionar las grandes enseñanzas sobre el orden, la justicia y la libertad en la Iglesia, enseñanzas que no descendían a cuestiones de método, conceptos dogmático-jurídicos o aspectos técnicos, en los que -como les había enseñado siempre- dejaba total libertad $^{103}$.

102 San Josemaría Escrivá de Balaguer, fundador del Opus Dei, es una de las grandes figuras precursoras del Concilio Vaticano II, como se lee en los documentos oficiales de su causa de beatificación (por ejemplo, Decreto de introducción de la Causa de Beatificación y Canonización del Siervo de Dios Fosemaría Escrivá de Balaguer, 19-II-1981, Rivista Diocesana di Roma III-IV (1981); Decreto sobre el ejercicio de las virtudes del Siervo de Dios Fosemaría Escrivá de Balaguer, 9-IV-1990, AAS 82 (1990) 1450-1455: 1450-1451). Pedro Lombardía comenzó a leer los escritos de Josemaría Escrivá de Balaguer en marzo de 1946, cuanto aún no había cumplido los 16 años de edad. Vid. P. Lombardía, Un hombre de Dios [Nuestro Tiempo 257 (1975) 371-383], en La personalidad del beato Fosemaría Escrivá de Balaguer, Pamplona 1994, 209-210. De 1949 a 1952 se formó en Roma al lado del fundador del Opus Dei. Cuando por su iniciativa surgió el Estudio General de Navarra en 1952, lo contó entre sus primeros profesores.

103 Pedro Lombardía se refirió personalmente a ese continuo estímulo y aliento, en un artículo publicado en 1975: «Me habló muchas veces de la importancia del estudio del Derecho Canónico y de la necesidad de que en el gobierno eclesiástico se procediera con sentido de justicia; le oí enjuiciar a veces situaciones y hechos de la vida de la Iglesia, de un modo que manifestaba su inmenso amor a la Esposa de Cristo y a la Sagrada Jerarquía y revelaba también su finísimo sentido de la prudentia iuris. [...] De sus palabras venían impulsos de trabajar con ilusión profesional, con un intenso amor a la Iglesia. Animaba con especial empeño a seguir con delicadeza las directrices del Magisterio de la Iglesia, a sentir con la Iglesia en el trabajo de enseñanza e in- 


\section{En el número 9 de la Constitución dogmática Lumen Gentium del Con- cilio Ecuménico Vaticano II, Lombardía encuentra formulado un principio que viene a confirmar de modo diáfano la doctrina sobre la libertad que ha aprendido de San Josemaría ${ }^{104}$ y que ha iluminado hasta entonces su trabajo}

vestigación del Derecho Canónico. [...] Sobre todo alentaba continuamente a buscar a Dios en el trabajo profesional [...]. Y junto al impulso al cumplimiento del deber, el aliento afectuoso de su corazón grande, del que tantos recuerdos conservo [...]. Es de justicia que "Ius Canonicum" resalte, como su importancia requiere, las enseñanzas de Mons. Escrivá de Balaguer sobre el orden, la justicia y la libertad en la Iglesia, llenas de profundidad y de sentido sobrenatural» (P. Lombardía, Acerca del sentido de dos noticias [Ius Canonicum 30 (1975) 14-38], en IdEM, Escritos..., vol. IV, Pamplona 1991, 97-134: 117-118). En otras ocasiones mencionó, resaltándolo especialmente, un encuentro que tuvo lugar en marzo de 1966: «Nunca olvidaré aquel 19 de marzo de 1966 en el que estuvimos con él tres canonistas, profesores de la Universidad de Navarra. Nos habló, con gran claridad, profundidad y sentido sobrenatural del espíritu de amor a la Iglesia y a la justicia con que debíamos realizar nuestro trabajo profesional. Amor a la Iglesia $\mathrm{y}$ a la justicia al mismo tiempo, que le llevaba a defender con vigor un régimen jurídico del ejercicio de los poderes jerárquicos, que impidiera su abusivo ejercicio en detrimento de la dignidad y libertad de los fieles» (P. LOMBardía, Amor a la Iglesia [en Homenaje a Mons. Fosemaría Escrivá de Balaguer, Pamplona 1986, 79-132], en IDEM, Escritos..., vol. V, cit., 467-502: 499); también se refirió a este encuentro de 19 de marzo de 1966 en P. LOMBARDÍA, Un hombre de..., cit., 210. En estas grandes ideas se centraba su impulso y aliento, con un delicado respeto a la libertad de cada uno: «Nunca, en cambio, me habló de cuestiones de método, de conceptos dogmático-jurídicos, de aspectos técnicos del Derecho Canónico [...] Recuerdo que el día 27 de octubre de 1973, cuando acudí a despedirme de él, al terminar unos días de estancia en Roma, se interesó por el trabajo de los canonistas de la Universidad de Navarra, y, con clara conciencia de su responsabilidad de Gran Canciller, me dijo que rezaba mucho por nosotros. Después añadió: "En cuestiones de fe no toleraré nada; en lo demás gran libertad"» (P. LOMBARDÍA, Acerca del sentido..., cit., 117).

${ }^{104}$ La doctrina sobre la libertad en San Josemaría Escrivá de Balaguer, fue objeto de varios estudios del eminente filósofo y teólogo P. Cornelio Fabro. En uno de ellos, con ocasión del segundo aniversario de su muerte, afirma: «Hombre nuevo para los tiempos nuevos de la Iglesia del futuro, Josemaría Escrivá de Balaguer ha aferrado por connaturalidad -y también por luz sobrenatural- la noción originaria de la libertad cristiana. Inmerso en el anuncio evangélico de la libertad entendida como liberación del pecado, confía en el creyente en Cristo, y, después de siglos de espiritualidades cristianas que se apoyaban en la prioridad de la obediencia, invierte la situación y hace de la obediencia una actitud y consecuencia de la libertad. Como un fruto de su flor, o más profundamente, de su raíz. [...] En plena sintonía con el Concilio Vaticano II -es más, se podría decir que superándolo en audacia- Monseñor Escrivá de Balaguer propone como primer bien para respetar y estimular el empeño temporal del cristiano, precisamente la libertad personal. [...] Esta actitud -nueva en la espiritualidad cristiana- de la prioridad fundante de la libertad, nace en Monseñor Escrivá de Balaguer [...] de una humilde y profunda aspiración a vivir el Evangelio» (C. FABRO, Un maestro di libertà cristiana: Fosemaría Escrivá de Balaguer, L'Osservatore Romano, 2-VII-1977, p. 5; versión castellana en Así le vieron - Testimonios sobre Mons. Escrivá de Balaguer, a cargo de R. SERRANO, Madrid 1992, 75-76). Cornelio Fabro vuelve sobre el tema en 1982: «Mons. Escrivá de Balaguer no duda en afirmar que la libertad salva al hombre. Pero no la simple libertad humana, sino la libertad cristiana, la que nos alcanza Cristo; que no es otra libertad, sino la misma libertad humana sanada y elevada por la gracia sobrenatural. De ahí que la salvación, como la misma libertad que salva, sea primariamente don de 
como canonista ${ }^{105}$, centrado -como ya hemos visto- en la persona humana, creada a imagen y semejanza de Dios, elevada por la gracia al orden sobrenatural, a la dignidad de hijos de Dios: «Este Pueblo mesiánico tiene por condición la dignidad y libertad de los hijos de Dios» ${ }^{106}$. Se trata ahora de sacar las consecuencias jurídicas de esa «dignidad y libertad de los hijos de Dios», de traducir en lenguaje jurídico los principios y elementos doctrinales del Concilio Ecuménico Vaticano II. Hay que elaborar un nuevo Derecho canónico para un nuevo periodo de la Historia de la salvación, que tenga como centro la persona redimida, el cristiano, hijo de Dios, con su dignidad y libertad: el Derecho canónico como orden de libertad ${ }^{107}$. Se propone partir de los estudios de los años anteriores en los que el verdadero protagonista es la persona. Se trata de retomar esos temas y conceptos canónicos, ya empleados -como hemos visto en las páginas anteriores- («derechos y deberes fundamentales»; «el bautismo como acto jurídico generador del estado fundamental en el ordenamiento canónico»; «la condición jurídica de christifidelis»; «el estatuto perso-

Dios. [...] sostiene [San Josemaría] decididamente el primado existencial que, en la economía salvífica, Dios ha concedido a la libertad del hombre. La fuerza y la originalidad con que el Fundador del Opus Dei afirma este primado en el orden sobrenatural, es quizá sólo comparable a la fuerza y originalidad con que Santo Tomás de Aquino había afirmado ese primado en el orden natural» (IDEM, El primado existencial de la libertad, en Mons. Fosemaría Escrivá de Balaguer y el Opus Dei (en el 50 aniversario de su fundación), a cargo de P. RODRÍGUEZ - P. G. ALVES DE SOUSA - J. M. Zumaquero, Pamplona 1982, 341-356: 341-342 y 356). El P. Fabro vuelve a dedicar unas páginas sobre la libertad en la enseñanza del fundador del Opus Dei en un amplio ensayo, sobre la doctrina de San Josemaría en sus escritos publicados, que lleva el significativo título de La tempra di un Padre della Chiesa, en C. FABRO - S. GAROFALO - M. A. RASCHINI, Santi nel mondo - Studi sugli scritti del beato fosemaría Escrivá, Milano 1992, 22-155; las páginas principalmente dedicadas a la libertad: 44-46, 70-73 y 119-131 (versión castellana El temple de un Padre de la Iglesia, en Santos en el mundo - Estudios sobre los escritos del Beato Fosemaría Escrivá de Balaguer, Madrid 21993, 23-135; las páginas principalmente dedicadas a la libertad: 41-43, 63-66 y 105-115). También puede verse, L. CLAVELL, La libertà conquistata da Cristo sulla Croce. Approccio teologico ad alcuni insegnamenti del Beato Fosemaría Escrivá sulla libertà, Romana 33 (2001) 240-269.

105 «La libertad, base de la responsabilidad -escribe Lombardía-, es la idea clave de todas las apreciaciones de Mons. Escrivá de Balaguer sobre el orden jurídico de la Iglesia. Por ello, el ejercicio de las facultades de gobierno ha de estar fundamentado en la justicia y reglado por el Derecho» (El Derecho en el actual..., cit., 452-453).

106 «Populus ille messianicus habet pro capite Christum [...]. Habet pro conditione dignitatem libertatemque filiorum Dei, in quorum cordibus Spiritus Sanctus sicut in templo inhabitat. Habet pro lege mandatum novum diligendi [...]. Habet pro fine Regnum Dei [...]» (CONC. VAT. II, Const. Lumen gentium, n. 9).

107 Sobre este tema, Sara Trueba elaboró su memoria de tesis doctoral en Derecho canónico, que defendió en el entonces «Centro Accademico Romano della Santa Croce», precisamente con el expresivo título El Derecho Canónico como un orden de libertad en el pensamiento de Pedro Lombardía, Roma 1989 (pro manuscripto). 
nal»; «derechos y deberes comunes a todos los fieles»; «derechos y deberes peculiares de los clérigos, laicos y religiosos»; «los derechos de los infieles»; «los derechos y deberes de los catecúmenos»), para estudiarlos con una intensificación en el aspecto de la libertad cristiana y para, de este modo, recalificarlos jurídicamente ${ }^{108}$. Javier Hervada, su discípulo y colaborador más inmediato, como ya se dijo, sitúa el punto de partida de estos proyectos ambiciosos en el mes de marzo de $1966^{109}$.

El día 3 de octubre de 1966, Pedro Lombardía pronunció en esta misma Aula Magna la lección inaugural del año académico 1966-1967 de la Universidad de Navarra: Los laicos en el derecho de la Iglesia ${ }^{110}$. Toma como punto de partida de su discurso el número 32 de Lumen gentium, acerca de la unidad y variedad en el Pueblo de Dios, para sacar las debidas consecuencias jurídicas: «Esta doctrina tiene unas consecuencias jurídicas claras. Por una parte, todos los fieles son susceptibles de una consideración igualitaria, por lo que se refiere a los derechos y deberes relacionados con la salvación personal. Pero, al mismo tiempo, es necesario distinguir las situaciones jurídicas que están en

$108 \ll$ El derecho canónico fue visto durante muchos siglos como disciplina [...], ley de la autoridad y cauce de obediencia. Esta visión del derecho canónico es parcialmente verdadera, en el sentido de que efectivamente toda legislación tiene en parte esa naturaleza. El problema reside en dar carácter absoluto a tal modo de entender el derecho. [...] Si es verdad que el derecho canónico es derecho de disciplina, también exige ser un derecho de libertad, una verdadera legislatio libertatis, que armonice autoridad y carismas, libertad y autoridad, derechos de los fieles y ejercicio de la jurisdicción. Lombardía se ocupó de estos temas en una serie de estudios, en los que supo conjugar elegantemente los términos a primera vista opuestos, dando una lección de ponderación y modernidad» (J. HeRvada, Personalidad científica..., cit., 493).

109 San Josemaría, «el 19 de marzo de 1966 nos abrió al inolvidable Pedro Lombardía y a mí un amplio panorama sobre la vida de la Iglesia, que iluminó nuestra mentalidad científica -especialmente en el aspecto metodológico- e hizo posible la innovación y la modernización que en la ciencia canónica habíamos intentado introducir desde el comienzo y que ahora está dando sus primeros y sazonados frutos. [...] no dejaron de salir aspectos como la historicidad de ciertas maneras de entender las formas de gobierno, la arbitrariedad, la necesidad de amparar los derechos de los fieles, entre ellos, la buena fama, etc. A medida que iba hablando, a Pedro Lombardía y a mí se nos iban rompiendo tabúes, tópicos, estereotipos e íbamos comprendiendo que muchas de las cosas que los canonistas calificaban de derecho divino, no eran más que formas culturales -y además caducadas- de presentar cosas que eran añadidos humanos o que, si bien tenían una base de derecho divino, respondían en buena parte a condicionamientos históricos. [...] Desembarazados de nuestros complejos, se nos abría un amplio panorama de renovación y modernización del derecho canónico, También le advertí a Lombardía que esta tarea no podríamos verla acabada: era cosa de un siglo» [J. Hervada, Confesiones de un canonista, Fidelium Iura 12 (2002) 61-68: 62 y 67].

110 P. LOMBARDía, Los laicos en el derecho de la Iglesia [Ius Canonicum 6 (1966) 339-374], en IDEM, Escritos..., vol. II, cit., 151-204. Se trata del primer estudio de esta nueva etapa de su producción científica, en el que las referencias a los documentos del reciente Concilio son muy abundantes. 
función de las distintas misiones eclesiales» ${ }^{111}$. A continuación, se refiere a la necesaria distinción entre fiel y laico: «Después del Concilio se hace totalmente imprescindible, para la exacta comprensión de la teoría de los sujetos del ordenamiento jurídico de la Iglesia, distinguir el significado de dos términos que frecuentemente se han utilizado como si fueran sinónimos: fiel y laico. El primero es genérico y designa a cuantos se integran en el Pueblo de Dios; el segundo es específico y designa a los que compete una determinada función en la vida de la Iglesia» ${ }^{112}$. «Clérigos, religiosos y laicos tienen en común su pertenencia al Pueblo de Dios, su participación en la condición de fiel; difieren, en cambio, en el contenido de sus específicas misiones eclesiales». Y consiguientemente esa diversidad «lleva consigo una diferencia de estatuto personal, que afecta a su condición jurídica en la Iglesia y en el mundo» ${ }^{113}$. Inmediatamente después, pasa a hablar del estatuto jurídico del laico en el Derecho canónico «que tiene en nuestros días una extraordinaria actualidad. [...] un clamor universal reclama una legislación eclesiástica que regule los derechos y deberes de los laicos». Pero una adecuada regulación del estatuto del laico, como el del clérigo o el del religioso, «requiere el marco [...] de una concepción del ordenamiento canónico como el Derecho del Pueblo de Dios», que siente firmemente las bases comunes de dichos estatutos en el estatuto genérico del fiel: «es necesario que el Derecho positivo del futuro establezca un equilibrio oportuno entre los derechos y deberes personales (a partir de la consideración de la dignidad de la persona humana y de su llamada al orden sobrenatural, independientemente de cuál sea su específica misión eclesial) y la de la regulación de los problemas que plantea el ejercicio del poder pasto-

111 Ibid., 154. «La tradicional afirmación de que la Iglesia es una sociedad jerárquica, y por tanto desigual, es rigurosamente exacta, pero insuficiente para una visión completa; porque no se pone de relieve de manera clara ni la responsabilidad que a todos los fieles compete en las tareas eclesiales, ni la consideración inmediata y personal (es decir, previa a las facultades ratione officii) de los que forman parte de la jerarquía» (ibid.). Y a continuación, poniendo de relieve la estrecha compenetración intelectual y colaboración científica con el primero de sus discípulos, añade: «A un profesor de nuestra Universidad, al Dr. Hervada Xiberta, ha cabido el mérito de formular por vez primera las consecuencias de esta matización en la teoría general del ordenamiento canónico, al poner de relieve las consecuencias jurídicas de la igualdad en relación con los medios de salvación y la desigualdad funcional; es decir, en relación con las diferentes misiones que a los hombres pueden corresponder en el conjunto de las tareas eclesiales [cfr. J. HeRvaDA, Fin y características del ordenamiento canónico, Ius Canonicum 2 (1962) 100-102; y posteriormente: IDEM, El ordenamiento canónico. I Aspectos centrales de la construcción del concepto, Pamplona 1966, 271-274)]» (ibid., 154-155).

112 Ibid., 155.

${ }^{113}$ Ibid., 159-160. 
ral. Difícilmente podrá marcarse el acento sobre el sentido de servicio que debe matizar la titularidad de las facultades basadas en el desempeño de misiones pastorales, si al mismo tiempo no se tutelan sinceramente los derechos que les corresponden como personas y como fieles a los llamados a ejercerlos. [...] Este tipo de cuestiones que afectan a la dignidad de la persona humana presentan una vertiente común a todos cuantos se agrupan en el Pueblo de Dios que "tiene por condición la libertad y dignidad de los hijos de Dios" [cita Lumen gentium, 9] y difícilmente podrán obtener las matizaciones específicas de los derechos propios del estatuto personal, si previamente no se han sentado firmemente las bases comunes en la consideración genérica de los derechos del fiel» ${ }^{114}$.

En esta lección inaugural, Lombardía resalta que los derechos y deberes específicos de los laicos «dimanan de la misión que les compete de "tratar y ordenar, según Dios, los asuntos temporales". Y en relación con ella es necesario subrayar tres principios fundamentales: libertad en la acción temporal, responsabilidad en la consecución del fin de la Iglesia y adecuación de la atención pastoral a las exigencias de la vida en el mundo» ${ }^{115}$. Al final de su discurso sobre el estatuto jurídico del laico, resume dicho estatuto en las que llegarían a ser conocidas como las diez tesis sobre los laicos, cuyo contenido aportará después, a su tiempo, a la Comisión pontificia para la revisión del «Codex» y que, en cierta manera, serán recogidas en el «Codex» de $1983^{116}$.

La doctrina integradora y realista, de depurada técnica, de Pedro Lombardía y sus discípulos, profesores de la Facultad de Derecho Canónico de la Universidad de Navarra, había contribuido, junto a otros colegas profesores universitarios, de modo determinante no sólo a consolidar el paso de la centralidad de la ley al primado de la persona en el Derecho canónico, sino también a la construcción de un nuevo Derecho canónico -el

${ }^{114}$ Ibid., 162-164. «En nuestros días se ha popularizado la afirmación de que la eclesiología tradicional era sólo una "hierarcología" y se ha visto en ello un obstáculo para la comprensión del papel del laicado en la Iglesia. No parece que pueda discutirse el fundamento de la afirmación, pero sí el limitado alcance que se atribuye a sus consecuencias. Esta cuestión no afecta sólo al laicado, sino a todos los fieles, que sea cualquiera su misión eclesial esperan ver atendidos los derechos que enlazan directamente con su condición de personas humanas y de bautizados. Su rectificación en el plano teológico y jurídico será beneficiosa para todos» (ibid., 165).

115 Ibid., 166.

116 Ibid., 190-191. Vid. J. Herranz, Il Prof. Pedro Lombardía e la nuova codificazione canonica, Ius Canonicum 26 (1986) 507-513: 510-511. 
Derecho del Pueblo de Dios ${ }^{117}$ - como orden de libertad, en los primeros años siguientes al Concilio Vaticano II, en las vísperas de la segunda Codificación.

\subsection{En los inicios de la segunda Codificación: fieles y laicos en la Iglesia}

En las mismas fechas de la lección inaugural de Pedro Lombardía y en coincidencia temática con ella, el egregio hombre de gobierno y eminente canonista Beato Álvaro del Portillo ${ }^{118}$, que se contaba entre los setenta Consultores ${ }^{119}$ nombrados el 17 de abril de 1964 por el Beato Pablo VI para asesorar a los Miembros de la Pontificia Comisión para la revisión del «Codex», constituida por Juan XXIII el 28 de marzo de $1963^{120}$, entregaba a esa Pontificia

117 Ese nuevo Derecho canónico quedará más adelante reflejado en la obra en colaboración con Javier Hervada que culminará en agosto de 1969, J. Hervada - P. Lombardía, El Derecho del Pueblo de Dios. Hacia un sistema de Derecho Canónico, I, Pamplona 1970.

118 Sobre el Beato Álvaro del Portillo y Diez de Sollano como jurista y canonista, pueden verse entre otros, A. DE Fuenmayor, Portillo y Diez de Sollano, Álvaro del, en furistas Universales, vol. IV, furistas del Siglo XX, a cargo de R. DOMINGO, Madrid-Barcelona 2004, 778-779; y J. OTADUY, Del Portillo, Alvaro, en Diccionario General de Derecho Canónico, vol. V, a cargo de J. OTADUY A. Viana - J. Sedano, Pamplona 2012, 1017-1021. Hace notar Errázuriz, al referirse al estilo del modo de hacer Derecho canónico del Beato Álvaro del Portillo, «su apertura a los colegas canonistas de las más diversas escuelas y tendencias, aunque sea obviamente prevalente la referencia a algunos autores con los cuales su pensamiento se encuentra en particular sintonía» y añade: «Es el caso por ejemplo, de Pedro Lombardía, de Javier Hervada y de otros canonistas de la Facultad de Derecho de la Universidad de Navarra, cuyos nombres aparecen frecuentemente en sus escritos. Pero ni la sintonía en tantos aspectos de fondo [reasumible quizás en el horizonte temático de la eclesiología del Concilio Vaticano II, anticipada en muchos de sus elementos principales por el carisma fundacional del Opus Dei] ni sus intensos lazos institucionales y afectivos con las Facultades de Derecho Canónico de la Universidad de Navarra y del Ateneo Romano della Santa Croce consienten encuadrar su personalidad en el ámbito de una determinada escuela. Esto resulta explicable en gran medida a la luz de un diverso retroterra existencial en su acercamiento al derecho canónico -para él no primariamente académico, sino práctico-, pero que resalta también aquella legítima libertad en las ciencias sagradas que, como anotaba Lombardía, era tan respetada y amada por el beato Josemaría Escrivá en sus hijos (cfr. Acerca del sentido de dos noticias, cit., 25-27)» (C. J. ERrázurIZ M., Un rapporto vitale con il diritto della Chiesa, en Ateneo Romano Della SANTA Croce, Rendere amabile la verità. Raccolta di scritti di Mons. Álvaro del Portillo, pastorali, teologici, canonistici, vari, Città del Vaticano 1995, 439449: 447-448). A este respecto, puede verse también, J. ECHEVARRía, In memoriam, en Rendere amabile la verità, cit., 9-23.

119 AAS 56 (1964) 473-474. Había sido Secretario de la Comisión conciliar sobre la disciplina del clero y del pueblo cristiano, donde tuvo un papel determinante en la elaboración del Decreto «Presbyterorum Ordinis» del Concilio Vaticano II: sobre este tema vid. la reciente monografía de M. VAldÉs MAS, La contribución de Álvaro del Portillo en la elaboración del Decreto Presbyterorum Ordinis y en su aplicación jurídica, Roma 2014.

120 AAS 55 (1963) 363-364. 
Comisión un amplio dictamen o «voto», de gran importancia en la segunda Codificación canónica, que lleva por título «Introducenda in iure canonico de laicorum notione deque eorum iuribus et officiis in Ecclesia» (Romae, 2 Octobris 1966$)^{121}$. Este dictamen, reelaborado, será publicado en 1969 con el título «Fieles y laicos en la Iglesia. Bases de sus respectivos estatutos jurídicos» (Pamplona 1969); monografía traducida en muchas lenguas que hoy es considerada un clásico de la doctrina canónica ${ }^{122}$.

En ese dictamen, el autor, antes del tratamiento de la noción de laico con sus específicos derechos y deberes, arranca de la persona física -por tanto, también del infiel y el catecúmeno- y sus derechos en el ordenamiento canónico. Después de afirmar que el Concilio Vaticano II nos da una visión de la Iglesia muy dinámica -es el Pueblo de Dios peregrinante que está abierto a todos los hombres- añade: «Es evidente que la Iglesia es sacramento universal de salvación, no sólo porque conduce a los bautizados a la plenitud, sino también en cuanto conduce a todos los hombres hasta la Iglesia». Una visión de la Iglesia «abierta a todas las posibilidades de la acción redentora, lleva necesariamente a una visión, igualmente abierta y amplia, de la relación de todos los hombres con la Iglesia». Coherentemente con todo esto, cita el siguiente pasaje del número 13 de «Lumen gentium» que, en cierta manera, manifiesta la noción de persona: «Así pues, todos los hombres están llamados a esta unidad católica del Pueblo de Dios, que prefigura y promueve la paz universal, y a ella pertenecen de diversos modos tanto los fieles católicos como los demás que creen en Cristo, como finalmente todos los hombres sin excepción, llamados por la gracia de Dios a la salvación». Y de la cita antedicha, concluye: «Donde hay actividad eclesial, allí hay también Derecho canónico, para regu-

121 Á. DEL PORTILLO, Introducenda in iure canonico de laicorum notione deque eorum iuribus et officiis in Ecclesia, Romae, 2 Octobris 1966 (pro manuscripto), 153 fols., en AGP (Archivo General de la Prelatura del Opus Dei), sec. B.1, n. 5165, XVII-1-6. El texto de este dictamen se puede consultar en Leuven, Faculty of Canon LaW, Archives Msgr, Willy Onclin, IV, n. 5.

122 Entre otros, vid. por ejemplo G. DALLA TORRE, Rileggendo un clasico della letteratura canonistica scritto da Alvaro del Portillo. Lo «status» giuridico dei laici e dei fedeli nella Chiesa, L'Osservatore Romano, 27-VI-1999, p. 7. El mismo año 1969, se había publicado por uno de los discípulos de Lombardía, P. J. VILADRICH, una importante monografía, ya citada, Teoría de los derechos fundamentales del fiel. Presupuestos críticos, Pamplona 1969, en coincidencia temática -al menos en parte- con Fieles y laicos: Viladrich concibe los derechos fundamentales del fiel, como explicitaciones subjetivadas de la voluntad fundacional de Cristo implícitas en la condición ontológico-sacramental del fiel, consistentes en esferas de autonomía (filiación divina) y esferas de actuación (sacerdocio común), nociones jurídicas primarias que se reconducen a la constitución divina de la Iglesia. 
lar los aspectos que tienen dimensión intersubjetiva en toda la actividad de la Iglesia ${ }^{123}$. La persona no bautizada, en general, viene considerada por dos notas en el Derecho de la Iglesia: a) una de carácter negativo: «la no recepción del bautismo»; «no tener personalmente los derechos y deberes específicos de los cristianos o "christifideles"»; consiguientemente «no es sujeto pasivo de las normas canónicas»; y b) otra nota, ésta de carácter positivo: «todo hombre, también el no bautizado, está incluido en la universal voluntad salvífica de Dios y es, como claramente puso de relieve la teología medieval, miembro en potencia del Cuerpo de Cristo "quod est Ecclesia"»; «el mismo no bautizado debe ser considerado persona física en el ordenamiento de la Iglesia, gozando de aquellos derechos reconocidos y tutelados por las normas canónicas, e incluso teniendo deberes, si ciertamente hay una base de acercamiento voluntario por parte del no bautizado» ${ }^{124}$. Con gran audacia, el Beato Álvaro del Portillo, reconduce esas dos notas a lo que denomina «Estatuto jurídico-canónico de la persona no bautizada», cuyas «bases fundamentales» son: a) «unos derechos y deberes fundamentales de derecho divino positivo, relacionados con su destinación "ad supernaturalia" por la voluntad salvífica de Dios» ${ }^{125}$; y b) «unas ciertas capacidades reconocidas por el ordenamiento canónico, que nunca implican deberes obligatorios sin el concurso de la voluntad del interesado, pero que una vez puesta en juego esta voluntad, generan verdaderas vinculaciones jurídico-canónicas» ${ }^{126}$. Sobre el caso concreto de los catecúmenos -aquellas personas no bautizadas que manifiestan expresamente su deseo de recibir el bautismo- afirma que «al catecúmeno debe reconocerse la condición de miembro que forma parte de la comunidad cristiana, aunque esto no sea

\footnotetext{
Á. DEL PORTILLO, Introducenda ..., cit., fols. 4-8.

Ibid., fols. 12-13.

125 Ibid. Concretamente, se refiere a: a) deber de inquirir la verdad religiosa y de abrazarla; b) derecho a la inmunidad de cualquier coacción en esa búsqueda e incorporación a la Iglesia; y c) el derecho a recibir la doctrina de salvación y el bautismo si lo piden «rite dispositi» (ibid.).

126 Ibid., fol. 14. Por ejemplo: contraer matrimonio canónico; ser testigo en una causa de canonización; donaciones a causas pías, etc. Estas capacidades no implican necesariamente en el no bautizado que hace uso de ellas una actitud de acercamiento a lo sobrenatural, sino que pueden deberse a razones puramente naturales: deseo de contraer matrimonio con una determinada persona; contribuir con su testimonio a la ejemplaridad de vida de un hombre; el aprecio por unas actividades «humanitarias», etc. Esto explica otro posible aspecto de la personalidad canónica de los no bautizados: «La Iglesia, inserta en el mundo, está encarnada; por tanto, el Derecho de la Iglesia, aunque tienda a la salvación de las almas, conoce situaciones y relaciones jurídicas que, al menos en la intención de algunos de los sujetos, no se explican por razones sobrenaturales» (ibid.).
} 
"pleno ac firmo iure"»; consiguientemente se le deben reconocer aquellos iura et officia «que provienen de su participación incoativa en la condición jurídica de fiel» ${ }^{127}$.

Después, pasa a tratar de un estatuto jurídico común de todos los bautizados cuyo contenido tiene como núcleo la condición constitucional de fiel -christifidelis- con los iura et officia christifidelium; y en forma de conclusión dice: «1. El Pueblo de Dios está constituido por todos los hombres regenerados por el bautismo, es decir por todos los christifideles. Este Pueblo de Dios tiene por Cabeza a Cristo, por condición la dignidad y libertad de los hijos de Dios y por fin la dilatación del Reino de Dios. - El nombre fidelis es nomen gratiae, y con este nombre son llamados todos y cada uno de los miembros del Pueblo de Dios; la condición jurídica de fiel se manifiesta en "iura et officia christianorum", que son comunes a todos los fieles: estos derechos y deberes deben ser establecidos con claridad en el nuevo CIC. 2. El plano fundamental del Pueblo de Dios está regido por la igualdad; por esta causa todos los fieles tienen derechos subjetivos fundamentales y primarios, en cuya esfera gozan de libertad. Estos derechos deben ser reconocidos escrupulosamente por todos y deben ser tutelados por la autoridad. La lesión de tales derechos siempre es ilícita, y frecuentemente lleva consigo la invalidez del acto jurídico lesivo de tales derechos, y esto porque estos derechos tienen su origen en el derecho natural y en el derecho divino positivo» ${ }^{128}$. Y acerca de los derechos de los fieles dice que su reconocimiento y tutela no es un problema de oportunidad política, sino una necesidad de la naturaleza misma de la ordenación jurídica y de la falibilidad de las personas tanto de los súbditos como de los titulares de la potestad. La protección de los derechos requiere una tutela legal que comprende tres aspectos: a) una expresa declaración en unas leyes fundamentales o constitucionales; b) la garantía de su efectivo ejercicio, a través del sistema de recursos administrativos y de la tutela judicial, incluso con el recuso contencioso-administrativo; y c) la distinción de funciones en el ejercicio de la potestad, sin perpetuar el equívoco de justificar su ausencia con el fácil recurso a la peculiaridad del Derecho canónico ${ }^{129}$.

A su vez, el laico, caracterizado en el Derecho anterior de modo negativo como el «no clérigo», ahora es considerado desde una óptica jurídica posi-

127 Á. DEL PoRTILLO, Introducenda..., cit., fols. 17-18.

128 Á. DEL PorTILlo, Introducenda..., cit., fol. 143.

129 Á. DEL PorTillo, Introducenda..., cit., fols. 73-74. 
tiva: ya que le corresponde por vocación una función específica consistente en buscar el Reino de Dios a través de la gestión y ordenación según Dios de las cosas temporales ${ }^{130}$, los derechos y obligaciones inherentes a la condición laical, tendrán su lugar en el estatuto de los laicos, cuyo contenido ocupa buena parte del dictamen o estudio de Álvaro del Portillo ${ }^{131}$. En otro momento, habla de la necesidad de aplicar los instrumentos técnico-jurídicos adecuados para integrar los derechos de los fieles y de los laicos en la vida de la Iglesia, añadiendo: «Consideramos que solamente si se procede así, la nueva legislación participará verdaderamente del espíritu del Concilio» ${ }^{132}$.

La tesis sostenida por el Beato Álvaro del Portillo acerca del fiel y del laico fue innovadora en el ámbito de la Ciencia canónica. Hasta entonces, las personas no bautizadas no se reconocían jurídicamente como «personas» en el Derecho de la Iglesia; las personas bautizadas se dividían radicalmente en tres categorías o estados: clérigos, religiosos y laicos ${ }^{133}$. Supo poner de relieve las consecuencias jurídicas de la condición de persona creada a imagen y semejanza del Creador; las consecuencias jurídico-canónicas del Bautismo: todos los bautizados tienen un común estatuto jurídico; todos son sujetos activos de la misión de la Iglesia; todos son llamados a la santidad. A su vez los laicos, tienen que santificar desde dentro las realidades temporales, con la más plena libertad y responsabilidad personales ${ }^{134}$. Era la traducción jurídica de lo que siempre había escuchado a San Josemaría Escrivá de Balaguer. El estudio de Álvaro del Portillo sobre los laicos tuvo mucha difusión entre

${ }^{130}$ Conc. VAT. II, Const. Lumen gentium, n. 31.

131 Á. DEL PorTILLO, Introducenda..., cit., fols. 59-139.

132 Á. DEL PorTillo, Introducenda..., cit., fol. 66.

133 La cuestión de la división de las personas en «estados» será tratada, con un enfoque crítico, por un profesor de la Universidad de Navarra, discípulo de Pedro Lombardía, en la muy conocida y valiosa monografía, J. Fornés, La noción de «status» en Derecho canónico, Pamplona 1975.

134 A este importante tema, se refiere con frecuencia el Papa Francisco en sus enseñanzas; por ejemplo: «Los laicos son simplemente la inmensa mayoría del Pueblo de Dios. A su servicio está la minoría de los ministros ordenados. Ha crecido la conciencia de la identidad y la misión del laico en la Iglesia. [...] Pero la toma de conciencia de esta responsabilidad laical que nace del Bautismo y de la Confirmación no se manifiesta de la misma manera en todas partes. [...] Si bien se percibe una mayor participación de muchos en los ministerios laicales, este compromiso no se refleja en la penetración de los valores cristianos en el mundo social, político y económico. Se limita muchas veces a las tareas intraeclesiales, sin un compromiso real por la aplicación del Evangelio a la transformación de la sociedad. La formación de laicos y la evangelización de los grupos profesionales e intelectuales constituyen un desafío pastoral importante» (PAPA FRANCISCO, Exhort. Apost. Evangelii Gaudium, 24-XI-2013, n. 102, AAS 105 (2013) 1019-1137, 1062-1063; versión en lengua castellana en http://w2.vatican.va/content/francesco/es/ apost_ exhortations/documents/papa-francesco_esortazione-ap_20131124_evangelii-gaudium.html). 
los Consultores y Padres de la Pontificia Comisión de reforma del «Codex» ${ }^{135}$ y las ideas allí expuestas se convirtieron en muy poco tiempo en doctrina común y criterio general para la redacción del nuevo Código, como así sucedió $^{136}$.

Hay que hacer notar que un año antes de la elaboración del dictamen del Beato Álvaro del Portillo, en el periodo comprendido entre la tercera y la cuarta y última etapa del Concilio Vaticano II, tuvieron lugar, con la aprobación del Beato Pablo VI, a partir del 6 de mayo de 1965, unas reuniones o sesiones de trabajo privadas o reservadas de los Consultores de la Pontificia Comisión revisora del «Codex» que estaban en Roma. Se constituyeron tres Comisiones que trabajaron durante el verano, redactándose tres Relaciones conclusivas de su estudio con las que se confeccionó una «Positio» impresa bajo el título «Quaestiones fundamentales» ${ }^{137}$, para el estudio de los Cardenales de la Comisión de revisión con vistas a la reunión plenaria de noviembre de $1965^{138}$. La primera Comisión constaba de once Consultores, entre los que

${ }^{135}$ Mons. Gerard PhiLIPs, que trabajó intensamente en la elaboración y redacción de las Constituciones del Vaticano II Lumen gentium y Gaudium et spes, escribió unas breves Adnotationes al estudio del Beato Álvaro del Portillo sobre los laicos, que había recibido, en la segunda quincena de noviembre de 1966, en su domicilio de Lovaina. Entre otras cosas escribió: «PLACET: a) quod insistitur super vocationem universalem ad sanctitatem, etiam pro laicis; quod etiam in legibus et praescriptionibus apparere debet; b) quod legislator canonicus intendit dignitatem aequalem omnium chistianorum agnoscere et iura laicorum tueri; imo quod illa iura dynamice concipiantur et promoveantur. Res in specie valet de libertate laicorum ad mentem suam aperiendam et de eorum cooperatione in Conciliis pastoralibus, tum dioecesanis tum parochialibus; c) quod dignitas humanae personae nulli homini denegatur, et quod aequalitas religiosa mulieris agnoscitur, ita ut etiam in praxim deducatur; d) quod inculcatur obligatio laicorum tum ad oboediendum Pastoribus, tum ad collaborandum cum eis, utque utrumque libenter fiat; e) quod legislatio particularis de catechumenis elaboratur, quia speciali modo iam ad Ecclesiam pertinent», en LeUven, CANON LaW, Willy Onclin, IV, n. 5.

136 J. L. GuTiÉrReZ, Mons. Álvaro del Portillo e la codificazione canonica, en Vir fidelis multum laudabitur. Nel centenario della nascita di Mons. Álvaro del Portillo, a cargo de P. GEFAELL, vol. I, Roma 2014, 103-131: 120; V. GómeZ-IgLesias C., Acerca de la contribución de Álvaro del Portillo al Derecho de la Iglesia, Ius Canonicum 54 (2014) 459-517 y en El beato Álvaro del Portillo y la Universidad, a cargo de M. Alonso DE Diego, Pamplona 2016, 62-110. Sobre la noción canónica de laico, puede verse una reciente y valiosa monografía, Á. GonZÁLEZ Alonso, La definición de laico en el Código de Derecho Canónico de 1983, Roma 2014; y también IDEM, Mons. Álvaro del Portillo y el Coetus Studiorum «De Laicis»: bases conceptuales para una definición del fiel laico en la Iglesia, en Vir fidelis..., cit., vol. II, Roma 2014, 335-350.

137 Quaestiones fundamentales, Typis Polyglottis Vaticanis, Città del Vaticano 1965. Se puede consultar en LeUven, CaNON LaW, Willy Onclin, I, n. 10.

138 Communicationes 1 (1969) 37. Me he ocupado detenidamente de esos trabajos preparatorios en V. GómeZ-Iglesias C., La Pontificia Commissio Codici Iuris Canonici Recognoscendo en los años del Concilio Ecuménico Vaticano II: el plan de revisión de las leyes de la Iglesia, Ius Canonicum 42 (2002) 109-133. 
estaba Álvaro del Portillo, y debía estudiar una primera cuestión previa, de gran importancia y que condiciona todo el trabajo posterior: «Quaestio utrum unus an duo Codices faciendi sunt, unus pro Orientalibus et alter pro aliis, praemisso Codice quodam Fundamentali» ${ }^{139}$. Nueve de los once Consultores «juzgan -dice la Relación- posible, e incluso necesaria, la elaboración de un Código constitucional o fundamental para toda la Iglesia, aunque la redacción de este Código conlleve no pequeñas dificultades» ${ }^{140}$. La Relación consigna los argumentos que los nueve Consultores mencionados dan a favor de esa posibilidad y necesidad ${ }^{141}$. Al hacerlo, la Relación sigue, en buena parte y casi textualmente, la exposición de Álvaro del Portillo, recogida en escrito fechado el 23 de septiembre de 1965. Como se puede comprobar, es la primera vez, que en un documento «oficial» de la Comisión de revisión del «Codex» se hace la propuesta de recoger «los derechos y deberes» comunes a todos los fieles, independientemente de si han recibido el Bautismo en la Iglesia latina o en una

139 Esta primera cuestión objeto de estudio se concretó todavía un poco más: 1 . Si es útil u oportuno confeccionar un único Código para toda la Iglesia; 2. Si es necesario conservar un doble Código de Derecho Canónico, uno correspondiente a la Iglesia de rito latino y otro a las Iglesias de ritos orientales; 3. Si prevalece esta segunda hipótesis, convendrá considerar si puede confeccionarse un Código fundamental, que contenga el derecho constitucional de la Iglesia, previo a ambos Códigos (Quaestiones..., cit., 10). El estudio de tan importante cuestión se realiza a lo largo del verano de 1965. Las diversas opiniones expuestas por los Consultores se confrontan en dos sesiones del 15 y 27 de septiembre (ibid.). El 4 de octubre el Cardenal Presidente P. Ciriaci solicita el parecer escrito de cada Comisión Preparatoria para redactar la citada «Positio» (ibid.). La relación de la primera Comisión se encuentra en las páginas 7 a 31 de Quaestiones fundamentales.

${ }^{140}$ Ibid., 19.

141 «a) Unitas Ecclesiae Christi: Melius eluceret unitas Ecclesiae si in unum colligantur illa quae omnibus communia sunt, quaeque exstant veluti fundamentum unitatis in legitima diversitate (Del Portillo, Welykyj, Onclin, Sansierra, Bateh, Ciprotti, Andrieu-Guitancourt, etc.); b) Necessitas pastoralis: Decet enim, ut principia fundamentalia iuridica scripta habeantur, e quibus clare constet tum Ecclesiae structura, tum summa iurium et officiorum, quibus christifideles in universa Ecclesia, sine distinctione Ritus, adstringuntur (omnes); c) Dialogus oecumenicus: Codex fundamentalis pro universa Ecclesia oecumenismo favet, nam clare in ipso determinari possunt illa quae pertinent ad constitutionem unicae Christi Ecclesiae; ex quo fratres seiuncti bene cognoscere valebunt quod sit fundamentum ab omnibus accipiendum et quae, e contra, liberae determinationi Ecclesiarum particularium (Occidentis et Orientis), sub auctoritate Supremi Legislatoris relinqui possunt; ideo Codex fundamentalis multum confert ad maiorem claritatem habendam in dialogo oecumenico (omnes); d) Ad suspicionem "latinizationis" tollendam: Si Codex fundamentalis, ius constitutionale Ecclesiae continens, redigatur, nemo unquam dicere audebit, Sedem Apostolicam velle imponere Ecclesiis orientalibus disciplinam Ecclesiae latinae; nam sub Codice fundamentali, unicuique Codici particulari, latino, videlicet et orientali, praemittendo, plures disciplinae et respectivi Codices particulares stare possunt, quod non obtinetur si Codex communis, in sensu ab Exc.mo Staffa et Rev.mo P. Tocanel explicato (cfr. 11, n. 1), conficiatur (omnes)» (Quaestiones fundamentales, 19-20). 
de las Iglesias Orientales católicas; y además recogerlos en un Código o Ley constitucional o fundamental de la Iglesia. Y esa propuesta, que aprueban los Consultores de la primera Comisión, la hace el Beato Álvaro del Portillo: «III. Acerca de la tercera bipótesis. 1) Me parece muy oportuno que sea redactado un Código fundamental, a semejanza de una ley constitucional, para la Iglesia universal, por estas razones: a) Mejor se refleja la unidad de la Iglesia si están reunidas todas aquellas cosas que son comunes, y que son como el fundamento de la unidad dentro de la legítima diversidad; además conviene tener una norma jurídica escrita, donde consten claramente tanto la estructura de la Iglesia como el conjunto de los derechos y deberes que obligan a los fieles cristianos, cualquiera que sea su Rito; b) tal Código favorece el ecumenismo, pues claramente en el mismo pueden determinarse aquellas cosas que pertenecen a la constitución de la única Iglesia de Cristo; a través del cual los hermanos separados podrán conocer bien cuál es el fundamento que debe ser aceptado por todos, y aquellas cosas que, por el contrario, pueden ser dejadas a la libre determinación de las Iglesias particulares, bajo la autoridad del Supremo Legislador; y por tanto el Código fundamental contribuirá mucho a tener una mayor claridad en el diálogo ecuménico» ${ }^{142}$.

El Segundo Pleno de los Miembros de la Pontificia Comisión Codificadora se reunió el 25 de noviembre de $1965^{143}$, para estudiar las cuestiones fundamentales previas que habían sido objeto de estudio en las tres Comisiones de Consultores, constituidas el 7 de mayo anterior. Los Miembros de la Pontificia Comisión tomaron nota de la posibilidad y conveniencia de una la Ley o Código fundamental y constitucional para la Iglesia, inclinándose mayoritaria-

142 «III. Quoad tertiam hypothesim. 1) Peropportunum mihi videtur ut Codex fundamentalis, ad instar legis constitutionalis, pro Ecclesia universa redigatur, propter has rationes: a) melius elucet unitas Ecclesiae, si in unum colligantur illa quae omnibus communia sunt, quaeque exstant veluti fundamentum unitatis in legitima diversitate; decet praeterea ut norma iuridica scripta habeatur, ubi clare constent tum Ecclesiae structura, tum summa iurium et officiorum, quibus Christifideles adstringuntur, quicumque sit eorum Ritus; b) talis Codex oecumenismo favet, nam clare in ipso determinari possunt illa quae pertinent ad constitutionem unicae Christi Ecclesiae; ex quo fratres seiuncti bene cognoscere valebunt quod sit fundamentum ab omnibus accipiendum et quae, e contra liberae determinationi Ecclesiarum particularium sub auctoritate Supremi Legislatoris relinqui possunt; ideo Codex fundamentalis multum conferet ad maiorem claritatem habendam in dialogo oecumenico» (Á. DEL PORTILLO, Addenda responsioni litteris prot. n. 192/65, diei 20-VII-1965, 23-IX-1965, pro manuscripto, en AGP, sec. B.1, n. 5165, II-1-6 bis. Cursiva del original).

143 Participaron en la reunión 39 Padres, entre los cuales se contaban los Patriarcas y Arzobispos Mayores de las Iglesias Orientales: vid. Communicationes 3 (1971) 54. 
mente a favor ${ }^{144} \mathrm{y}$ manifestando sus deseos ${ }^{145}$ de que se continuase el trabajo, para, una vez concluido, someter los resultados al Pleno de la Pontificia Comisión. Por lo que se refiere a la preparación de ese proyecto de Código o Ley fundamental, el Cardenal Ciriaci, Presidente de la Pontificia Comisión Codificadora encargó a Mons. Willy Onclin, Secretario Adjunto de dicha Comisión Pontificia, que preparase un primer anteproyecto de índole claramente jurídi$\mathrm{Ca}^{146}$, conocido como «Prima quaedam adumbratio propositionis Codicis Ecclesiae Fundamentalis» (VI-1966) ${ }^{147}$. Una especial Comisión constituida «ad hoc» ${ }^{148}$ se reunió en julio de $1966^{149}$ y dio un parecer muy positivo sobre la previsión de una ley fundamental para la Iglesia, declarando la «Prima

${ }^{144}$ Se manifestaron a favor 27 Miembros de la Pontificia Comisión; 6 en contra o, al menos, no favorables a su redacción hasta después de la confección de los nuevos Códigos; se abstuvieron 7 y, como era oportuno, el Presidente de la Comisión: vid. Communicationes 1 (1969) 114 y 3 (1971) 54-55, 172.

145 Para los datos anteriores y para la historia del proyecto de Código o Ley constitucional o fundamental de la Iglesia hasta 1971, vid. J. L. GuTIÉRREZ, Situación presente y perspectivas futuras de la ley fundamental de la Iglesia, Ephemerides Iuris Canonici 27 (1971) 273-295 y en IDEM, Estudios sobre la organización jerárquica de la Iglesia, Pamplona 1987, 119-143. Sobre el contexto doctrinal y los primeros pasos del proyecto entre los años 1959 (anuncio de la renovación del Derecho de la Iglesia) a 1969 (elaboración del primer Schema Legis Ecclesiae Fundamentalis), C. SAHLI LECAROS, La revisión de las leyes de la Iglesia: contexto doctrinal y primeros pasos del proyecto de una Ley fundamental, Roma 2011. Para todo el iter del proyecto de Ley fundamental, vid. D. CENALMOR, La Ley Fundamental de la Iglesia. Historia y análisis de un proyecto legislativo, Pamplona 1991; V. GÓMEZIgLeSIAS C., Libertad..., cit., 93-147; IDEM, O projecto de Lex Ecclesiae Fundamentalis, en Deveres e Direitos dos Fiéis na Igreja, Lusitania Canonica 5, Lisboa 1999, 247-275.

146 Communicationes 3 (1971) 173.

147 Communicationes 1 (1969) 114. El texto se encuentra en LeUven, Canon, Willy Onclin, II, n. 6: Codex Ecclesiae Fundamentalis (Prima quaedam adumbratio propositionis). También se encuentra recogido como Anexo n. 3 en C. SAHLi LeCAROS, La revisión..., cit., 431-458. Hace algunos años se publicó una sinopsis comparativa de diversos proyectos, tanto oficiales como privados, de la Ley fundamental en O. G. M. Boelens, Synopsis «Lex Ecclesiae Fundamentalis», Leuven 2001.

148 El 26 de junio de 1966 se constituyó una comisión especial de teólogos y canonistas para estudiar este primer anteproyecto, entre los que se encontraban los reconocidos teólogos Mons. Carlo Colombo y Mons. Gerard Philips y los canonistas Mons. Klaus Mörsdorf, el Padre W. Bertrams S.J. y el Prof. Pio Ciprotti, siendo Relator Mons. Onclin (vid. Leuven, CanON LaW, Willy Onclin, II, n. 7).

149 La comisión especial se reunió los días 26 y 27 de julio de 1966, ampliada ahora con algunos miembros del Grupo Central o de Coordinación, entre los que se encontraba el Beato Alvaro del Portillo. Sobre algunos aspectos de la doctrina constitucional y administrativa del Beato Álvaro del Portillo, vid. J. CANOSA, La tutela giuridica della dignità e della libertà dei fedeli cristiani nonché del carattere ministeriale della Gerarchia. Riflessioni circa il contributo di Álvaro del Portillo per lo sviluppo del diritto amministrativo canonico, en Vir fidelis..., cit., vol. II, 535-546; M. DEL Pozzo, Il contributo documentale di Álvaro del Portillo al progetto della «Lex Ecclesiae Fundamentalis» (1966-1973), en ibid., 501-516; IDEM, Il pensiero costituzional-canonistico di Álvaro del Portillo, Ius Ecclesiae 26 (2014) 289-310; C. SAHLI, Álvaro del Portillo y los primeros pasos del proyecto de una Ley Fundamental para la Iglesia, en Vir fidelis..., cit., vol. II, 517-533. 
adumbratio» como una buena base de estudio, aunque convendría introducir cambios importantes, entre los que se cuentan que la noción y constitución de la Iglesia que la ley manifieste sea congruente con la doctrina de la Iglesia como Pueblo de Dios propuesta por el Concilio Vaticano II y que defina la misión y los derechos de los christifideles en la Iglesia ${ }^{150}$. A estos cambios se refiere Álvaro del Portillo, en continuidad dinámica de profundización con sus mencionadas aportaciones del verano de 1965 , en sus propuestas, de palabra y consignadas por escrito, presentadas en la sesión de 26 de julio de $19666^{151}$. Entre otras sugerencias de indudable novedad y amplia visión jurídica, se incluyen las siguientes: a) «en la noción que se dé sobre la Iglesia, debe aparecer más claramente el aspecto carismático y pneumatológico, además de la unidad fundamental -en lo que se refiere a la dignidad y misión- que existe entre todos los miembros del Pueblo sacerdotal de Dios: es decir, una relación fraterna primaria, que precede a la diferenciación jerárquica de los ministerios»; b) «ha de tratarse más ampliamente de los derechos y obligaciones de aquellos que componen el Pueblo de Dios, derechos y obligaciones que provienen tanto del derecho natural como del derecho divino positivo, tanto los que corresponden a todos los miembros del Pueblo de Dios - como son por ejemplo el derecho de asociación, el derecho a la acción judicial para defender los propios derechos, etc.- como aquellos que dicen relación a una categoría peculiar de miembros del Pueblo de Dios, según específicas y particulares vocaciones, a las que corresponden estatutos personales diversos» ${ }^{152}$. Después de un intercambio de conversaciones y cartas, sucesivas a esa sesión de finales de julio, Álvaro del Portillo presentó el 19 de octubre de 1966 a Mons. Onclin ${ }^{153}$, para su trabajo

Communicationes 1 (1969) 114.

151 Á. DEL PorTILlo, 26-VII-1966, pro manuscripto, en AGP, sec. B.1, n. II-1-10; el texto de este dictamen se puede consultar en Leuven, CanON LaW, Willy Onclin, II, n. 8 y en V. GómezIgLESIas C., Acerca de la contribución..., cit., 486-487.

152 «a) in notione Ecclesiae, manifestius apparere debet aspectus charismaticus et pneumatologicus, necnon fundamentalis unitas -quoad dignitatem et missionem- quae viget inter omnia membra Populi sacerdotalis Dei: nempe relatio fraterna primaria, quae praecedit ipsimet differentiationi hierarchicae ministeriorum; [...] c) amplius agendum est de iuribus et obligationibus eorum qui Populum Dei efformant, quae iura et obligationes e iure naturali atque e iure divino positivo proveniunt, et respiciunt tum omnia membra Populi Dei -uti e. g. ius associationis, ius actionis iudicialis ad vindicanda propria iura, etc.-, tum etiam aliquam peculiarem categoriam membrorum Populi Dei, iuxta specificas et particulares vocationes, quibus correspondent diversa statuta personalia; [...]» (ibid.).

153 Sobre la especial sintonía personal entre Willy Onclin y Álvaro del Portillo, vid. V. GómeZIgLesias C., Acerca de la contribución..., cit., especialmente, 490-495. 
de reelaboración de la «Prima adumbratio» ${ }^{154}$, un texto completo de proyecto de Ley fundamental ${ }^{155}-\ll$ Lex Fundamentalis Ecclesiae Catholicae»- ${ }^{156}$, acompañado de un documento explicativo «Notanda circa schema Legis Fundamentalis Ecclesiae» ${ }^{157}$. El texto incluía -sobre todo en el capítulo II «De Christifidelibus»- las importantes novedades aportadas por Álvaro del Portillo, en sus pareceres anteriores antes mencionados, concretamente las sugerencias y propuestas de 26 de julio 1966 y la doctrina sobre fieles y laicos de la relación de 2 de octubre de 1966: la noción de christifidelis, los derechos y deberes del fiel, la diversificación jerárquica y carismática de los fieles, entre ministros sagrados, religiosos y laicos con sus derechos y obligaciones ${ }^{158}$. Mons.

${ }^{154}$ Mons. Willy Onclin será Relator del proyecto de ley Fundamental hasta el último Schema de 1980.

155 El Beato Álvaro del Portillo, consciente del gran trabajo que en esas fechas tenía entre manos, sobre todo la redacción de la mencionada relación sobre los laicos que oficialmente se le había solicitado, pidió a algunos colegas profesores de la Universidad de Navarra que le ayudasen a título personal en el cometido de redacción de ese borrador de texto de Ley fundamental, concretamente a aquellos con los que tenía una particular sintonía científica: el reconocido civilista Amadeo de Fuenmayor, los canonistas Pedro Lombardía y Javier Hervada y el teólogo Alfredo García Suárez. La relativa documentación, en AGP, sec. B.1, n. 5165, II-2.

156 El texto de 66 fols. constaba de 79 cánones divididos en 5 capítulos: I. De Ecclesia Christi (cann. 1-8); II. De Christifidelibus (cann. 9-27); III. De Sacra Hierarchia (cann. 28-50); IV. De iure Ecclesiae (cann. 51-67); y V. De Ecclesia et hominum communitate (cann. 68-79). A los cánones se acompañaban 137 Notae que contenían las fuentes de cada canon, en su casi totalidad fuentes magisteriales del Concilio Vaticano II. Además incluía una Clausula finalis con tres parágrafos que establecían el valor fundamental y constitucional de la Ley Fundamental: todas las otras leyes de la Iglesia deberían inspirarse o ser congruentes con ella $(\$ 1)$, debería estar dotada de prevalencia: no sólo las demás leyes no podrían ser contrarias a sus cánones sino que todas las demás leyes deberían interpretarse y aplicarse de acuerdo con ella, sin posibilidad de sentencia de juez contraria $(\$ 2)$; posibilidad de recurrir ante un tribunal estable, vicario del Papa -a modo de tribunal constitucional-, contra cualquier disposición legal contraria $(\$ 3)$. Este texto como de autor desconocido, sin fecha, puede verse erróneamente catalogado en cuanto a la fecha (1973), en LeUven, Canon LaW, Willy Onclin, II, n. 47; probablemente por la novedad del contenido y de la redacción del texto en el inmediato postconcilio, el competente profesor C. Van den Wiel, organizador y alma del Archivo Willy Onclin, lo situó siete años más tarde.

157 Este documento explicativo de 11 fols. se compone de cinco apartados: I. De principio legalitatis; II. De principio tutelae iuridicae; III. De principio divisionis functionum; IV. De organis auxiliaribus Hierarchiae; V. De momento buius schematis quoad oecumenismum (1. Notio Ecclesiae quatenus est Corpus Ecclesiarum; 2. Functio et characteres Iuris in Ecclesia; 3. Tutela iuridica varietatis ecclesialis; 4. Nonnulli canones indolis oecumenicae). Este documento, también catalogado erróneamente como de autor desconocido, puede verse en LEUVEN, CANON LaW, Willy Onclin, II, n. 8.

158 En el Archivo de Mons. Onclin, se encuentra un documento que contiene amplias referencias a un nuevo Schema Legis Fundamentalis Ecclesiae Catholicae que sin ninguna duda es el entregado por el Beato Álvaro del Portillo el 19 de octubre de 1966, manifestación concreta de que este texto fue objeto de cuidadoso estudio en la preparación del nuevo anteproyecto encomendado a Mons. Onclin a finales de julio de 1966: el documento de 17 fols. -falta el fol. 5- está redactado en latín, sin título ni autor ni fecha, en LEUven, CANON LaW, Willy Onclin, II, n. 10. 
Willy Onclin, después de un intenso trabajo de varias semanas en la reelaboración del anteproyecto de ley fundamental, en el que colaboró estrechamente Mons. Gerard Philips ${ }^{159}$, pudo finalmente fechar el 1 de marzo de 1967 su segundo anteproyecto titulado «Lex Ecclesiae Fundamentalis (Altera quaedam adumbratio propositionis) $\gg^{160}$. Este anteproyecto incluía importantes novedades. Por primera vez, la ley aparece bajo la denominación «Lex Ecclesiae Fundamentalis», que de un modo u otro se mantendrá a lo largo de todo el dilatado «iter» hasta el 1 de diciembre de 1981 en que se abandonó por el momento la idea de su promulgación. El primer artículo «De Ecclesia ut Populo Dei» (cann. 3-28) del primer capítulo «De Ecclesia» (cann. 1-48) -en línea con el vigoroso pensamiento del Beato Álvaro del Portillo- junto a la presentación de la Iglesia como Pueblo de Dios -manifestando mejor el aspecto carismático y la unidad fundamental en lo que se refiere a la dignidad y misión que existe entre todos los fieles-, explicita la noción de christifidelis, además de incluir un estatuto jurídico fundamental del fiel estableciendo sus derechos y obligaciones primarios y fundamentales en diez cánones («Christifidelium officia et iura primaria seu fundamentalia», cann. 13-23). El último canon de ese apartado contempla el derecho del fiel a tutelar sus derechos legítimos mediante el recurso a la autoridad competente (canon 23). El primer artículo concluye con la exposición de la diversidad que existe entre los fieles por razón de su estado («Diversitas christifidelium ratione status», cann. 24-28). Los días 3 y 4 de abril de 1967, este anteproyecto fue sometido a estudio del $\ll$ Coetus Centralis Consultorum» que lo aprobó «quoad substantiam» ${ }^{161}$. Es oportuno resaltar que es la primera vez que la Comisión Codificadora incluye en un proyecto legislativo de modo preciso las bases constitucionales de los diferentes estatutos

159 AGP, sec. B.1, n. 5165, II-2.

${ }^{160}$ El texto constaba de 88 cánones divididos en 3 capítulos: I. De Ecclesia (cann. 1-48); II. De Ecclesiae muneribus (cann. 49-78); III. De Ecclesia et hominum consortione (cann. 79-88). Puede consultarse en Leuven, CaNON LaW, Willy Onclin, II, n. 9: Lex Ecclesiae Fundamentalis (Altera quaedam adumbratio propositionis). Está recogido también como Anexo n. 4 en C. SAHLI LECAROS, La revisión..., cit., 459-509.

161 Leuven, Canon LaW, Willy Onclin, II, n. 12. También en Communicationes 1 (1969) 115; Communicationes 3 (1971) 173; Communicationes 4 (1972) 120. El 28 de marzo de 1967, Mons. Gerard Philips, ante la imposibilidad de asistir a la reunión programada en abril para estudiar el segundo anteproyecto de ley fundamental presentado por Willy Onclin -que previamente había revisado y al que había dado el visto bueno-, envió un breve parecer en el que expresaba tres cuestiones concretas; la primera la formulaba así: «Hay que insistir en la fundamental igualdad de todos los fieles, al mismo tiempo que en la desigualdad funcional, como expuso D. Á. del Portillo» (Leuven, Canon LaW, Willy Onclin, I, III, n. 4; II, n. 11). 
personales -ministros ordenados, laicos y religiosos- y los hace preceder, también por primera vez, del estatuto constitucional del fiel, común a todos los diversos estatutos personales, incluyendo una lista de derechos y deberes, calificados de primarios y fundamentales: esta formulación permanecerá a lo largo de todo el «iter» de la Ley fundamental y de su último proyecto pasará al nuevo «Codex Iuris Canonici» de 1983.

$\mathrm{Al}$ mismo tiempo que se elaboraba el segundo anteproyecto de ley fundamental de marzo de 1967, se elaboraban en la Secretaría de la Pontificia Comisión codificadora unos Principios que pudiesen servir de fundamento y guía para toda la revisión del Código de Derecho Canónico. La Secretaría no se limitó a ordenar las propuestas y sugerencias de los Consultores del Consejo Coordinador ${ }^{162}$, sino que el Secretario redactó lo que llamó un resumen de los Principios propuestos por ellos, pero que en realidad es un proyecto completo que incluye nueve Principios ${ }^{163}$. Estos nueve Principios fueron convenientemente estudiados, discutidos, enmendados y aprobados durante las sesiones del 4 al 7 de abril. Además se aprobó un décimo Principio «De nova disposi-

${ }^{162}$ Los Consultores miembros del entonces llamado Coetus coordinationis seu centralis hacen sus propuestas acerca de los posibles Principios directivos a finales de 1966 y principios de 1967 (E. Eid, P. Bertrams S.J., Á. del Portillo, Mons. G. Violardo, P. Huizing S.J., Mons. P. Palazzini y P. Gómez O.P.). La Secretaría va estudiando y ordenando las diversas propuestas, trabajo que culmina en un foglio d'ufficio de 36 páginas que lleva por título Principia directiva generalia pro Codicis Iuris Canonici recognitione, fechado en Roma el 31 de enero de 1967 (LEUvEN, CANON LAW, Willy Onclin, I, III, n. 4). El Beato Álvaro del Portillo había hecho llegar su propuesta que lleva por título Principia Generalia Directiva pro recognitione CIC, de 13 folios, en la que redactados en latín se incluyen diez posibles principios para dirigir la reforma del Código que responden en buena parte a su doctrina canónica anteriormente expuesta en sus «vota» o dictámenes para la Pontificia Comisión: I. De functione ministeriali iuris; II. De spiritu pastorali iuris; III. De ambitu Iuris Canonici; IV. De iuridica consideratione catechumenorum; V. De radicali aequalitate omnium christifidelium; VI. De ecclesiasticis communitatibus; VII. De iuridica delimitatione publicae potestatis; VIII. De principio legalitatis; IX. De principio tutelae iuridicae; y X. De verborum significatione. Constituyen estos diez principios propuestos un valiosísimo testimonio del vigoroso pensamiento canónico del Beato Álvaro del Portillo y de su apuesta radical, sin ninguna reticencia, por un nuevo Derecho Canónico. Puede consultarse el texto completo en V. GómEZIgLesias C., Acerca de la contribución..., cit., 503-507; un resumen y autorizado comentario en J. L. GutiérreZ, Mons. Álvaro del Portillo..., cit., 125-128.

163 Leuven, Canon Law, Willy Onclin, I, III, n. 3: Principia quae Codicis Iuris Canonici recognitionem dirigere possunt, sin fecha. Los nueve Principios del proyecto del Secretario de la Pontificia Comisión son: $1^{\circ}$ De indole iuridica Codicis; $2^{\circ}$ De fori interni iuridicitate; $3^{\circ}$ De quibusdam mediis fovendi curam pastoralem in Codice; $4^{\circ}$ De incorporatione facultatum specialium in ipso Codice; $5^{\circ}$ De principio subsidiarietatis; $6^{\circ}$ De tutela iurium personalium; $7^{\circ}$ De agnoscendis iuribus subiectivis; $8^{\circ}$ De extensione principii territorialitatis; $9^{\circ}$ De diminutione poenarum ecclesiasticarum. Las diferencias de forma y de fondo entre el proyecto del Secretario y el texto de las propuestas de los Consultores se manifiestan en muchos de los Principios. 
tione systematica Codicis Iuris Canonici», que no figuraba en el proyecto ${ }^{164}$. Apenas terminada la reunión de abril de 1967 del «Coetus Centralis», la Secretaría de la Comisión elaboró un documento que lleva por título «Principia quae Codicis Iuris Canonici recognitionem dirigant», que contiene el texto aprobado de los diez Principios ${ }^{165}$. Sobre la base de los estudios de los ya mencionados primeros anteproyectos de la ley fundamental, el Grupo Central de Consultores aprobó que se incluyera entre los principios directivos la doctrina expuesta por el Beato Álvaro del Portillo sobre la igualdad radical y diversidad funcional, sobre el estatuto fundamental de los fieles y los estatutos personales de acuerdo con esa diversidad: «Se propone una cuestión muy importante que ha de resolver el futuro Código: en qué modo han de definirse y tutelarse los derechos de las personas. [...] A cada fiel se deben reconocer y tutelar sus derechos, tanto los contenidos en la ley natural o divino-positiva, cuanto los que congruentemente se les derivan en razón de la condición social que en la Iglesia adquieren o poseen. Y ya que no todos tienen la misma función, ni a todos conviene el mismo estatuto, justamente se propone que en el futuro Código, por la radical igualdad que debe existir entre todos los fieles -tanto por su dignidad humana cuanto por el bautismo recibido-, se establezca un estatuto jurídico común a todos ellos, antes de tratar de los derechos y deberes propios de las diversas funciones eclesiásticas» ${ }^{166}$. Pero el Grupo Central de Consultores

164 Leuven, Canon Law, Willy Onclin, II, n. 12: Coetus Centralis Consultorum, Sessio diebus 3-7 aprilis habita, II, Principia quae Codicis Iuris Canonici recognitionem dirigant, 18-IV-1967, fols. 8-9, 13-14, 16-18, 21-24, 27-28, 33-34.

165 Leuven, Canon Law, Willy Onclin, I, III, n. 6. Los diez Principios aprobados por el Coetus Centralis Consultorum son los siguientes: I) De indole iuridica Codicis; II) De fori externi et interni positione in iure canonico; III) De quibusdam mediis fovendi curam pastoralem in Codice; IV) De incorporatione facultatum specialium in ipso Codice; V) De applicando principio subsidiarietatis in Ecclesia; VI) De tutela iurium personarum; VII) De ordinanda procedura ad tuenda iura subiectiva; VIII) De ordinatione territoriali in Ecclesia; IX) De recognoscendo iure poenali; X) De nova dispositione systematica Codicis Iuris Canonici.

166 Principio directivo, n. 6 -De tutela iurium personarum-, Communicationes 1 (1969) 82-83. Parece oportuno hacer notar que San Josemaría Escrivá de Balaguer, a partir de su experiencia como fundador del Opus Dei y con su fino sentido jurídico, pone en guardia, por estas fechas, contra la tentación de que la tarea que, en virtud de la diversidad funcional, corresponde al laico en la misión de la Iglesia se considere aisladamente, en vez de considerarla a partir de la comprensión de la condición común de bautizado, de fiel: «No son estas tareas -la específica que corresponde al laico como tal laico y la genérica o común que le corresponde como fiel- dos tareas opuestas, sino superpuestas, ni hay entre ellas contradicción sino complementariedad. Fijarse sólo en la misión específica del laico, olvidando su simultánea condición de fiel, sería tan absurdo como imaginarse una rama verde y florecida que no pertenezca a ningún árbol. Olvidarse de lo que es específico, propio y peculiar del laico o no comprender suficientemente las 
no se limitó a una declaración de los derechos comunes a todos los fieles, sino que quiso añadir que era necesario establecer unos medios de efectiva tutela de esos derechos (Principio directivo $7^{\circ}$ ) ${ }^{167}$. Los Principios fueron examinados detalladamente y recibieron el placet del Beato Pablo VI, que manifestó su deseo de que fuesen estudiados por la primera Asamblea General del Sínodo de Obispos, prevista para el otoño de ese año. Efectivamente, los diez principios fueron presentados por el Cardenal Felici en el Aula sinodal resaltando de modo especial los Principios $6^{\circ}$ y $7^{0}{ }^{168}$, a continuación fueron estudiados y aprobados uno a uno por el Sínodo el 7 de octubre de $1967^{169}$. Unos días más

características de estas tareas apostólicas seculares y su valor eclesial, sería como reducir el frondoso árbol de la Iglesia a la monstruosa condición de puro tronco» (SAN J. EsCRIVÁ DE BALAGUER, Espontaneidad y pluralismo en el Pueblo de Dios, entrevista concedida a Pedro Rodríguez y publicada en la revista Palabra, octubre 1967; recogida en Conversaciones con Mons. Escrivá de Balaguer, Madrid 1968, 25).

167 Principio directivo, n. 7 -De ordinanda procedura ad tuenda iura subiectiva-: «Pero esto no basta para asegurar convenientemente, en nuestro derecho, una tutela de los derechos. Efectivamente han de ser reconocidos unos verdaderos y propios derechos subjetivos sin los cuales es difícil concebir una ordenación jurídica de la sociedad. Por tanto conviene proclamar en el derecho canónico que el principio de la tutela jurídica ha de aplicarse de igual modo a los superiores y a los súbditos, de modo que desaparezca completamente cualquier sospecha de arbitrariedad en la administración eclesiástica. Esta finalidad solamente se puede obtener mediante unos recursos sabiamente dispuestos por el derecho, de modo que quien considere lesionado su propio derecho por una instancia inferior lo pueda eficazmente restaurar en la instancia superior [...]» (Communicationes 1 [1969] 83-84; la traducción es mía).

168 El Cardenal Pericle Felici puso de relieve en el Aula Sinodal que así como el Concilio defendió que en todas partes ha de respetarse la dignidad de la persona humana y sus inviolables derechos, radicados en la naturaleza humana, con más razón deberá hacerse en la Iglesia «ya que los fieles por el bautismo se insertan en el misterio de Cristo e incorporados a Cristo adquieren una nueva dignidad y personalidad. De ahí que se proponga que "en el Código, por la radical igualdad que debe existir entre todos los fieles, se establezca un estatuto jurídico común a todos ellos". En él juzgamos que de modo explícito han de definirse los derechos y respectivas obligaciones», ya que la Iglesia necesita una ley -dice con expresivas palabras del Beato Pablo VI del 27 de mayo de 1967- «no tanto por mero ejercicio de autoridad, sino precisamente para tutela de la esencia y de la libertad, tanto de los entes morales como de las personas físicas que componen la Iglesia misma» (Communicationes 1 [1969] 59). Y añade que por eso en los principios se proponen los medios que parecen «más oportunos y más adecuados al derecho eclesiástico, comprobados también por la experiencia, para tutelar los derechos que competen a las personas, tanto morales como físicas, ya por derecho natural o divino-positivo ya por el derecho eclesiástico dispuesto con ingenio y con amor por la autoridad de la Iglesia» (Communicationes 1 [1969] 89-90; la traducción es mía).

169 Los Principia quae Codicis Iuris Canonici recognitionem dirigant aprobados por la primera Asamblea General del Sínodo de los Obispos se encuentran en las pp. 77-85 del número 1, año 1969, de la revista Communicationes, así como en la p. 100 se puede consultar el resultado de las votaciones de cada principio uno por uno: todos ellos recibieron el placet de más de los dos tercios de los presentes; el resto fueron placet iuxta modum excepto solamente cinco non placet. El resultado de las votaciones de los dos principios a que nos referimos en el texto fue el siguiente: sobre $187 \mathrm{miem}-$ 
tarde, concretamente el 17 de noviembre de 1967, el Cardenal Presidente Pericle Felici, enviaba a todos los Miembros y Consultores de la Pontificia Comisión para la revisión del Código de Derecho Canónico un ejemplar oficial de los Principios directivos ${ }^{170}$. En la carta de acompañamiento enviada a los Consultores, se puede leer: «Estudia atentamente estos principios, enunciados y aprobados por el Sínodo, y confórmate a ellos, tanto en los informes que has de preparar como en las sentencias que has de emitir, de tal modo que la común labor de preparar los esquemas de los cánones se adhiera íntimamente a la doctrina y al verdadero y genuino espíritu del Concilio Vaticano II, teniendo siempre presente el sano progreso de la ciencia del derecho canónico» ${ }^{171}$.

La vigorosa doctrina científica -equilibrada, clara, aguda y profunda- acerca de la persona, tanto bautizada como no bautizada, su dignidad y libertad y sus derechos y obligaciones fundamentales, del que luego sería Gran Canciller de la Universidad de Navarra, el Beato Álvaro del Portillo, en estos primeros años de la segunda Codificación canónica, junto a la de otros de sus colegas canonistas, empezando por Mons. Willy Onclin, significó una apuesta decidida por un nuevo Derecho para la Iglesia y su contribución se reveló decisiva e insustituible.

\subsection{El antijuridicismo y la ley canónica}

Es obvio que cuando se habla del paso de la centralidad de la ley al primado de la persona, no se pretende caer en la falacia de negar la importancia de la ley en el Derecho, sino de colocarla en su justo lugar. El Derecho no se funda en la norma positiva ni en la voluntad de la autoridad o del poder de la

bros del Sínodo de los Obispos, el principio n. 6 recibió 150 placet y 37 placet iuxta modum y el n. 7 , a su vez, recibió 148 placet y 39 placet iuxta modum; no hubo por tanto ningún voto contrario.

170 PCCICR, Principia quae Codicis Iuris Canonici recognitionem dirigant a Pontificia Commissione proposita et primi generalis coetus «Synodi Episcoporum» examini subiecta, Typis Polyglottis Vaticanis, Città del Vaticano 1967. Una versión -más sintética- de los Principios directivos de la reforma se encuentra en el Praefatio del Codex Iuris Canonici, promulgado por Juan Pablo II el 25 de enero de 1983.

171 «His principiis, per Synodum enucleatis et approbatis, velitis attente studere ad eaque Vos conformare sive in votis exarandis sive in sententiis expromendis, ita ut communis in apparandis canonum schematis labor arcte cohaereat cum doctrina et vero ac genuino spiritu Concilii Vaticani II, prae oculis quidem habita sana canonici iuris scientiae progressione» (PCCICR, Litterae Prot. N. 1105/67, 17-XI-1967, en AGP, sec. B.1, n. 5165, I-1-9). Sobre la acogida de estos principios en el Código de 1983, en la legislación posterior y en la concreta experiencia jurídica de la Iglesia, vid. Pontificia Università Della SANTa Croce, I principi per la revisione del Codice di Diritto Canónico. La ricezione giuridica del Concilio Vaticano II, a cargo de J. Canosa, Milano 2000, 764 pp. 
que la norma es expresión; el Derecho tiene su fundamento en el hombre y en su Creador. «La norma como manifestación de la voluntad potestativa de la autoridad, como instrumento a través del cual la autoridad cumple su función, es ciertamente un momento necesario de la experiencia jurídica; pero la norma no tiene en sí misma su justificación, ni tampoco en el poder de la que es expresión, sino que hay que considerarla en su fundamento y valorarla por los fines que debe alcanzar en relación al hombre y a la respuesta que da a la necesidad de justicia del hombre, en sus variadas condiciones de su vida, comprendida la religiosa» ${ }^{172}$. En cambio, cuando el positivismo afirma la centralidad de la ley como manifestación de la voluntad del poder y cuando además se identifica el tenor literal de la ley con el Derecho, se corre el riesgo de provocar una reacción paradójica de antijuridicismo: esto explica, al menos en parte, lo que gráficamente se ha expresado como «la conversión que han sufrido algunos hombres de Iglesia desde el amor al texto hasta el odio al derecho. Del legalismo al antijuridicismo. Un viaje que ha hecho tanta gente en la segunda mitad del siglo $\mathrm{XX} \gg^{173}$.

El Magisterio de la Iglesia se manifestó sobre estas cuestiones ya en el inmediato postconcilio. El Beato Pablo VI, en la Audiencia General de 17 de agosto de 1966, se pronunciaba del siguiente modo: «Nos sabemos bien que desde muchos sitios se mira con antipatía la actividad legisladora de la Iglesia, como si fuese opuesta a la libertad de los hijos de Dios, antitética al espíritu del Evangelio, obstáculo para las espontáneas manifestaciones de los carismas propios del Pueblo de Dios, freno del desarrollo histórico del organismo eclesiástico, que resulta extraño y retrasado con respecto al desarrollo histórico de la sociedad temporal. Pero no vemos como la Iglesia católica, si quiere ser fiel y consecuente con los principios constitutivos de su divino Fundador, pueda prescindir de darse a sí misma un "derecho canónico"» ${ }^{174}$. Y añade: «Quien

172 G. Lo CASTRO, Il Mistero del Diritto..., cit., 108.

173 J. OTAdUY, Positivismos ingenuos..., cit., 42.

174 AAS 58 (1966) 800-801. El Beato Pablo VI continúa: «se la Chiesa è società visibile, gerarchica, impegnata ad una missione salvatrice, che non ammette se non una univoca e determinata realizzazione, custode d'una Parola, che deve essere conservata rigorosamente e diffusa apostolicamente, responsabile della salute dei propri fedeli e dell'evangelizzazione del mondo, non può fare a meno di darsi leggi, coerentemente derivate dalla Rivelazione e dai bisogni sempre insorgenti della sua vita sia interiore, che esteriore. Per correggere i possibili inconvenienti del così detto "giuridismo", il primo rimedio sarà non tanto nell'abolire la legge ecclesiastica, quanto nel sostituire a prescrizioni canoniche imperfette o anacronistiche altre prescrizioni canoniche meglio formulate» (ibid., 801). 
alimenta una aversión preconcebida hacia la ley de la Iglesia no tiene el verdadero sensus Ecclesiae, y quien cree que hace progresar a la Iglesia, simplemente demoliendo las estructuras de su edificio espiritual, doctrinal, ascético, disciplinar, en la práctica destruye la Iglesia, acoge el espíritu negativo de quien la abandona, y de quien no la ama y no la edifica», para concluir: «Es necesario recordar estas cosas, hijos queridísimos, porque nos encontramos en los inicios de un nuevo y grande periodo legislativo de la Iglesia. [...] y más bien que hacer alarde de desinterés o de desprecio por las normas canónicas, buscaremos comprender su espíritu, observar sus preceptos y apreciar sus solicitudes pastorales. Así se ama a la Iglesia y así se participa en el flujo de su siempre joven vitalidad» ${ }^{175}$. Unos meses más tarde, concretamente el 27 de mayo de 1967, tuvo lugar en Roma una solemne celebración académica en el cincuentenario de la promulgación del «Codex» de 1917, con la presencia del Beato Pablo VI ${ }^{176}$, quien, entre otras cosas, dijo: «La Iglesia, por ser una comunidad no sólo espiritual, sino visible, orgánica, jerárquica, social y ordenada, tiene necesidad también de una ley escrita y requiere órganos adecuados que la promulguen y la hagan observar, no tanto por mero ejercicio de autoridad, sino precisamente para tutela de la esencia y de la libertad, tanto de los entes morales como de las personas físicas que componen la Iglesia misma» ${ }^{177}$. La norma canónica debe ser obedecida y este deber de acatamiento compromete en principio toda la vida del cristiano: su conciencia y su conducta externa. Presentándose «siempre en el contexto de las relaciones del hombre con Dios y con la pretensión de estar en congruencia con el designio de Cristo acerca de su Iglesia, la norma canónica goza de una auctoritas muy superior a la de cualquier otra norma humana» ${ }^{178}$. La búsqueda de congruencia entre

Ibid., 802.

176 En las palabras de saludo al Papa, el Pro-Presidente de la Comisión revisora, Mons. Pericle Felici, después de referirse a la necesidad de una nueva Codificación y a la misión del nuevo Código pasó a mencionar el cometido de la ley en la Iglesia, resaltando significativamente los derechos de los fieles: «La legge nella comunità ecclesiale è espressione di giustizia, ma anche di carità, la virtù che tutte le altre rende perfette. Proprio per questo essa -la legge- contribuirà non solo a salvaguardare gli inderogabili diritti della persona umana dei figli di Dio ed il retto ordine della società ecclesiale, ma a creare altresì tra i fedeli e, per riflesso, tra tutti gli uomini il vincolo che di tutti farà una cosa sola in Cristo, nella tranquillitas ordinis che è propria della pace» [Communicationes 1 (1969) 58].

177 Ibid., 59; también en Insegnamenti di Paolo VI, vol. V, 1967, Città del Vaticano 1968, 952.

178 P. LombardíA, Norma y ordenamiento jurídico en el momento actual de la vida de la Iglesia [Ius Canonicum 16 (1976) 61-80; La Norma en el Derecho Canónico. Actas del III Congreso Internacional de Derecho Canónico. Pamplona 10-15 octubre 1976, vol. II, Pamplona 1979, 847-866], en IDEM, Escritos..., vol. IV, Pamplona 1991, 191-215: 197. 
el Derecho divino y el Derecho humano al mismo tiempo que atribuye una radical eficacia vinculante a la norma canónica «provoca una actitud de libertad ante la norma humana, que excluye excesivas concesiones al absolutismo legal», de modo que se han de «conjugar adecuadamente dos exigencias, tan sentidas en la actualidad en la vida de la Iglesia, como son la obediencia eclesiástica y la libertad de los hijos de Dios» ${ }^{179}$. Sobre los Pastores de la Iglesia pesa el deber «de cumplir personalmente -y en el ejercicio de su función- las normas canónicas; de proceder con diligencia al desempeño de la parte que a cada uno corresponde en la derogación, reforma y producción de normas y de llevar a cabo los actos de gobierno que les competen para exigir el cumplimiento del Derecho a quienes están encomendados a sus cuidados» ${ }^{180}$. La ley no se identifica con el Derecho, aunque sea un aspecto importantísimo del orden jurídico eclesial.

\subsection{El primado de la persona y sus derechos}

Cuando se habla del paso de la centralidad de la ley al primado de la persona no se quiere decir sólo que las leyes -y la Jerarquía de la que proceden en cuanto dotada de la potestad de régimen- deben respetar la dignidad y la libertad de la persona y sus derechos, sino sobre todo que el primer sujeto eclesial, el titular primario de derechos y deberes jurídicos en la Iglesia, es la persona humana ${ }^{181}$. La salvación en Cristo y en la Iglesia es universal, destinada por la misericordia divina a todos y cada uno de los hombres, lo que jurídicamente significa que toda persona humana tiene derecho a recibir el anuncio de la Palabra de Dios confiada a la Iglesia, así como el sacramento del bautismo rite dispositus y los demás sacramentos, especialmente la Eucaristía. A estos dos bienes jurídicos salvíficos principales -la Palabra de Dios y los Sacramen-

179 Ibid., 198.

${ }^{180}$ Ibid., 208.

181 En este punto sigo a C. J. Errázuriz M., Corso fondamentale sul diritto nella Chiesa. I. Introduzione. I soggetti ecclesiali di Diritto, Milano 2009, 183-197. Vid. también J. Hervada, Persona, Derecho y fusticia [en Persona e ordinamento nella Chiesa. Atti del II Congresso Internazionale di Diritto Canonico, Milano 10-16 settembre 1973, Milano 1975, 91-104], en IDEM, Vetera et nova. Cuestiones de Derecho Canónico y afines (1958-2004), Pamplona 22005, 235-245; IDEM, Los derechos fundamentales del fiel a examen [Suplemento Lex Nova Fidelium Iura de derechos fundamentales del fiel 1 (1991) 197-248], en IDEM, Vetera et..., cit., 681-715; IDEM, La dignidad y libertad de los bijos de Dios [Fidelium Iura 4 (1994) 9-31], en IDEM, Vetera et..., cit., 745-760; C. J. ERRÁZuRIZ M., La persona nell'ordinamento canonico: il rapporto tra persona e diritto nella Chiesa, Ius Ecclesiae 10 (1998) 3-36. 
tos- hay que añadir otros dos bienes jurídicos salvíficos, especialmente importantes en el ámbito jurídico: la legítima libertad y autonomía de la persona humana en la Iglesia y el ejercicio en su favor de la sagrada potestad de la Jerarquía eclesiástica: predicar e interpretar con autoridad la Palabra de Dios («munus docendi»); celebrar el culto y administrar los sacramentos («munus sanctificandi») y dirigir, moderar y gobernar el Pueblo de Dios («munus regendi»). Estos bienes salvíficos de la persona, constituyen sus derechos propios, en tanto en cuanto le son debidos por otros: deberes de respetar o de actualizar la destinación de tales bienes a las personas, que competen de modo peculiar a la Jerarquía de la Iglesia -como se acaba de mencionar-, pero que competen también a todo fiel cristiano, que debe vivir la justicia en la Iglesia: respetando los derechos de todos los demás fieles cristianos e inseparablemente los derechos de toda la comunidad eclesial mediante la fiel observancia de la disciplina de la Iglesia. El derecho es una realidad propia de la persona.

Hay que hacer notar también que cuando se habla del primado de la persona y sus derechos en el orden jurídico-canónico, se está hablando de un personalismo que no tiene nada en común con el individualismo de matriz liberal ${ }^{182}$. «La persona humana nunca puede ser pensada con independencia de su íntrinseca socialidad y de las formas concretas en que ésta se realiza ${ }^{183}$. El hombre es naturalmente socio de los demás, la comunidad política es natural, la persona no es anterior en el sentido temporal a la sociedad civil, persona y comunidad política son simultáneas: por eso, cuando decimos que la persona es «anterior» a la comunidad política, queremos decir que la persona «tiene una esfera de ser y de fines no absorbida por la sociedad civil y, por lo tanto,

${ }^{182}$ La tesis liberal clásica -del primitivo liberalismo- y del iusnaturalismo moderno, que tuvo diversos matices según los autores, afirma que los derechos del hombre, los derechos fundamentales de la persona humana, son anteriores a la sociedad civil; sociedad civil que no sería un hecho natural, sino un producto del hombre a través del contrato social o pacto de la sociedad. «Por naturaleza el hombre sería asocial. En este estado natural el individuo humano sería soberano, titular -como escribió Hobbes- del ius in omnia erga omnes. Éste sería propiamente el derecho natural del individuo humano, el ius naturale entendido como derecho subjetivo o potestas. Este ius naturale sería el haz o conjunto de poderes ilimitados del hombre frente a los demás hombres. [...] Estos derechos naturales irrenunciables son los derechos del hombre o derechos humanos, los cuales, según la tesis expuesta, son anteriores a la sociedad civil. Sólo en esta construcción liberal puede afirmarse que los derechos fundamentales del hombre son anteriores a la comunidad política» (J. HeRVADA, Los derechos fundamentales..., cit., 699-700). Sobre la dignidad de la persona humana y su no subordinabilidad que, entendidas desde una sólida perspectiva metafísica, comportan la negación de los postulados del liberalismo individualista, vid. F. OCÁRIZ, Naturaleza, Gracia y Gloria, Pamplona 2000, 20-65.

183 C. J. Errázuriz M., Corso fondamentale..., cit., 184. 
que posee un núcleo de posibilidades de acción, no cedidas ni concedidas por la comunidad política, porque es anterior o preexistente a esa pretendida cesión o concesión»; y que los derechos naturales o fundamentales del hombre, son «innatos o inherentes a su condición de persona y, en consecuencia, preexisten, son anteriores, a su declaración por el derecho positivo», en definitiva, son iura nativa ${ }^{184}$.

La persona en la Iglesia, en virtud de su elevación al plano sobrenatural por el bautismo, es inseparable del misterio de comunión en que consiste la misma Iglesia. Todo fiel está obligado a respetar los derechos de sus hermanos: en primer lugar, los de vivir en la comunión eclesial y de poder ejercer la legítima libertad en la Iglesia. También bajo este aspecto el fiel desempeña un papel de protagonista en el Derecho de la Iglesia. El fiel cristiano es titular de derechos inherentes a su condición de bautizado. Tales derechos -como se ha visto antes- se refieren a los bienes salvíficos de la comunión: Palabra de Dios, Sacramentos, legítima libertad del mismo bautizado, la potestad de la Jerarquía. Fuera de la relación de comunión del bautizado con Dios y con la Iglesia, no son comprensibles ni los derechos ni las obligaciones de las personas en la Iglesia: no hay verdaderos derechos de la persona del fiel si se desconectan de las exigencias de la comunión. La comunión es una realidad dotada de consistencia objetiva, ontológica y jurídica: es el núcleo más profundo de la Iglesia de Cristo ${ }^{185}$. A veces parece que se teme que los derechos fundamentales del fiel sean entendidos en clave de contraposición con las exigencias de la comunión y de la constitución jerárquica de la Iglesia, como si fueran dos dimensiones que se hacen la competencia. Las exigencias de la comunión justifican tanto la libertad del fiel como las atribuciones de potestad a la Jerarquía: las dos dimensiones son en teoría completamente armónicas, aunque en la práctica esa armonía encierre innegables dificultades, ligadas a la componente humana de la realidad eclesial ${ }^{186}$. La autoridad jerár-

${ }^{184}$ J. HeRVADA, Los derechos fundamentales..., cit., 700-701. Es significativa la insistencia de San Juan Pablo II de calificar como «objetivos» los derechos naturales o fundamentales del hombre en la Enc. Redemptor hominis, 4-III-1979, n. 17, AAS 71 (1979) 254-324, 296-297 y 299-300.

185 C. J. ERrázUriz M., Corso fondamentale..., cit., 37-40, 184.

$186 \ll$ Mientras el Pueblo de Dios no llegue en su peregrinar a la meta escatológica, estará sometido al riesgo de las "almas que hacen barricadas con la libertad" [SAN J. EsCRIVÁ DE BALAGUER, La libertad, don de Dios, en IDEM, Amigos de Dios, Madrid 1977, n. 29]. Pero no olvidemos que ese riesgo no se plantea sólo en relación con el abuso de los derechos fundamentales, con la consiguiente necesidad de la formalización jurídica de sus límites. Esta amenaza puede también manifestarse en forma de abusos en el ejercicio de la función jerárquica. Frente a tal riesgo, deben 
quica constituye en su esencia un servicio a todos y cada uno de los miembros del Pueblo de Dios y el ejercicio de la potestad es una forma necesaria de ese servicio $^{187}$. Hay un verdadero derecho de la persona del bautizado a que la constitución jerárquica de la Iglesia sea respetada y a que la autoridad jerárquica sea ejercida con fidelidad a la voluntad fundacional de Cristo: lo contrario sería un atentado contra el patrimonio jurídico esencial de cada persona en la Iglesia ${ }^{188}$. Lombardía se manifestó siempre contrario a una actitud dialéctica en orden a la promoción de la libertad en la Iglesia: «Los derechos fundamentales de los fieles, radicados en la participación del bautizado en la vida de Cristo, tienen en el propio Señor su principal y más genuino titular; los fieles, como he apuntado en otras ocasiones, tienen una titularidad "vicaria". Resulta, por tanto, que a nadie es lícito fundamentar en la libertad que el Señor nos ganó $(\mathrm{Gal} 5,1)$, cualquier acción que atente contra la unidad del Cuerpo de Cristo, que es la Iglesia» ${ }^{199}$. «Sin embargo, bajo otro aspecto, el bien jurídico de la constitución jerárquica está subordinado al de la libertad de los fieles, ya que la Jerarquía está llamada por su naturaleza a favorecer el ejercicio de la libertad en la Iglesia» ${ }^{100}$. Además «la comunión, no sólo no elimina las personas singulares, sino que las potencia. El sujeto de la salvación es cada persona, y esto se refleja en la dimensión jurídica, en la que ninguna verdadera exigencia de la comunión puede justificar el atentar contra los derechos fundamentales de cada cristiano» ${ }^{191}$. No es sólo contrario a la comu-

formalizarse en el ordenamiento canónico, con prudente audacia, los derechos fundamentales del fiel» (P. LOMBARDía, Los derechos fundamentales del cristiano en la Iglesia y en la sociedad [en Les Droits Fondamentaux du Chrétien dans l'Église et dans la Societé. Actes du IV Congrès International de Droit Canonique, Fribourg Suisse-Freiburg i. Br.-Milano 1981, 15-31] en IDEM, Escritos..., vol. IV, cit., 493-515: 512).

187 De este tema me he ocupado hace unos años, tratando de poner de relieve que no se puede contraponer en la Iglesia autoridad como servicio y autoridad como potestad, vid. V. GÓMEZ-IGLESIAS C., Acerca de la autoridad como servicio en la Iglesia, en Pontificium Consilium DE Legum TEXTIBUS INTERPRETANDIS, Ius in vita et in missione Ecclesiae, Acta Symposii Internationalis Iuris Canonici occurrente X Anniversario promulgationis Codicis Iuris Canonici diebus 19-24 aprilis 1993 in Civitate Vaticana celebrati, Città del Vaticano 1994, 193-217: 213-217.

«Nella misura in cui la Gerarchia costituisce la garanzia esterna dell'autenticità dell'esperienza cristiana, non c'è dubio che ad essa devono aderire fedelmente tutti i fedeli. La loro libertà trova in tale adesione la garanzia di adeguamento alle esigenze della verità salvifica» (C. J. ERRÁZURIZ M., La persona..., cit., 30).

189 P. LOMBARDÍA, Una monografía sobre los derechos fundamentales del fiel [Prólogo a P. J. VILADRICH, Teoría de los derechos..., cit., XVII-XXVII], en IDEM, Escritos..., vol. III, cit., 107-119: 118-119.

190 Ibid.

191 C. J. Errázuriz M., Corso fondamentale..., cit., 185. 
nión desobedecer a la legítima autoridad, sino también pisotear la legítima libertad: no existe mayor y más insidiosa amenaza contra la obediencia que la injusticia. Por eso, la persona del fiel, cuya perfección es inseparable de la verdadera realización de la comunión, ocupa el primado en el Derecho de la Iglesia.

\subsection{Un pseudopersonalismo canónico y su valoración en una alocución de Benedicto XVI}

Este personalismo del que se habla aquí, tampoco tiene que ver con un tipo de «personalismo» canónico que -como ya puso de relieve Errázuriz en 1998- pretendiendo defender el primado de la persona sobre las instituciones canónicas asume frecuentemente un concepto de Derecho que se identifica con las leyes positivas. Pretende superar tal concepto de Derecho «pero sin lograr concebir las exigencias jurídicas verdaderamente objetivas de la persona. Las reivindicaciones son por el contrario de tipo subjetivista, y tienden a absolutizar la libertad de la persona que se vería obstaculizada por el derecho objetivo» ${ }^{192}$. Este «pseudopersonalismo» canónico ha ido en aumento hasta el punto de ser objeto de atención por parte de Benedicto XVI en una importante alocución de 2012 al Tribunal de la Rota Romana -la penúltima de su Pontificado-, con motivo del tema de la interpretación de la ley ${ }^{193}$. «En los últimos tiempos algunas corrientes de pensamiento han puesto en guardia contra el excesivo apego a las leyes de la Iglesia, empezando por los Códigos, juzgándolo, precisamente, como una manifestación de legalismo. En consecuencia, se han propuesto vías hermenéuticas que permiten una aproximación más acorde con las bases teológicas y las intenciones también pastorales de la norma canónica, llevando a una creatividad jurídica en la que cada situación se convertiría en factor decisivo para comprobar el auténtico significado del precepto legal en el caso concreto. La misericordia, la equidad, la oikonomia tan apreciada en la tradición oriental, son algunos de los

192 C. J. ERRÁzuriz M., La persona..., cit., 5. «Come manifestazioni concrete di questa mentalitá si pensi alle argomentazioni favorevoli ad introdurre il favor personae o libertatis quale principio chiave del diritto matrimoniale canonico, capovolgendo cosí l'"istituzionalistico" favor matrimonii; oppure alla contrapposizione tra diritti dei fedeli e attribuzioni della Gerarchia, nel senso che la crescita degli uni comporterebbe la diminuzione delle altre e viceversa» (ibid.).

193 BenEDICTO XVI, Discorso in occasione dell'inaugurazione dell'anno giudiziario del Tribunale della Rota Romana, 21-I-2012, AAS 104 (2012) 103-107. 
conceptos a los que se recurre en esa operación interpretativa ${ }^{194}$. El problema de esta corriente -bastante difundida, y más en los últimos tiempos- no es obviamente que se recurra a estas instituciones jurídicas ni a las intenciones pastorales y, mucho menos, a las bases teológicas, sino al hecho de que se convierta en «creativa del derecho» ${ }^{195}$. El juicio es diáfano: «este planteamiento no supera el positivismo que denuncia, limitándose a sustituirlo por otro en el que la obra interpretativa humana se alza como protagonista para establecer lo que es jurídico» ${ }^{196}$. Efectivamente la sustitución del texto de la ley por la propia voluntad es un positivismo de consecuencias mucho más perjudiciales que el positivismo legal ${ }^{197}$. La diferencia entre este planteamiento y la llamada del Papa -hoy emérito- a la insoslayable necesidad de mirar y partir de la realidad legislada, se encuentra en el hecho de que «falta el sentido de un derecho objetivo que hay que buscar, pues éste queda a merced de consideraciones que pretenden ser teológicas o pastorales, pero que al final se exponen al riesgo de la arbitrariedad» ${ }^{198}$. Hay que observar la realidad a la luz del magisterio eclesiástico y no de particulares presupuestos pseudoteológicos o pseudopastorales que se quieren hacer valer a pesar de la existencia de una legislación contraria y, sobre todo, de las exigencias intrínsecas de la misma realidad ${ }^{199}:$ «la hermenéutica legal se vacía: en el fondo no interesa comprender la disposición de la ley, ya que ésta puede adaptarse dinámicamente a cualquier solución, incluso opuesta a su misma letra. Ciertamente existe en este caso una referencia a los fenómenos vitales, pero de los que no se capta la dimensión jurídica intrínseca», es decir, «la verdad jurídica que hay que amar, buscar y servir» ${ }^{200}$. La verdadera interpretación está regida por la búsqueda de la verdad y el verdadero Derecho es inseparable de la justicia: «El principio, obviamente, también vale para la ley canónica, en el sentido de que ésta no puede encerrarse en un sistema normativo humano, sino que debe estar unida a un orden justo de la Iglesia, en el que existe una

\footnotetext{
194 Ibid., 104-105.

195 E. BAURA, La realtà disciplinata quale criterio interpretativo giuridico della legge, Ius Ecclesiae 24 (2012) 705-717.

196 Benedicto XVI, Discorso..., cit., 105.

197 J. OTADUY, Positivismos ingenuos..., cit., 39. Vid. también, IDEM, Los medios interpretativos de la ley canónica (y su relación con las distintas doctrinas de la interpretación), en IDEM, Fuentes, Interpretación, Personas, Pamplona 2002, 263-313.

198 Benedicto XVI, Discorso..., cit., 105.

199 E. BAURA, La realtà disciplinata..., cit., 715-716.

200 BeNEDICTO XVI, Discorso..., cit., 105.
} 
ley superior. En esta perspectiva la ley positiva humana pierde la primacía que se le querría atribuir, pues el derecho ya no se identifica sencillamente con ella ${ }^{201}$.

\section{A modo de Conclusión: un discurso de SAN JuAn Pablo II en 2003}

El legislador del «Codex Iuris Canonici» de 1983, San Juan Pablo II, en los últimos años de su dilatado y fecundo pontificado, tuvo ocasión de hacer balance del tiempo transcurrido desde la promulgación del nuevo Código latino. Un momento emblemático y solemne fue el viernes 24 de enero de 2003, con ocasión de la conmemoración del vigésimo aniversario del «Codex Iuris Canonici», organizada por el Pontificio Consejo para los Textos Legislativos, donde pronunció un importante discurso ante numerosísimos canonistas que estábamos presentes ${ }^{202}$.

En ese discurso, San Juan Pablo II, en primer lugar, rememora con gran realismo el clima antijurídico postconciliar que -como se ha visto- había denunciado ya el Beato Pablo VI: «Felizmente, las voces de contestación del derecho ya han quedado superadas. Sin embargo, sería ingenuo ignorar todo lo que queda aún por hacer para consolidar en las actuales circunstancias históricas una verdadera cultura jurídico-canónica y una praxis eclesial atenta a la dimensión pastoral intrínseca de las leyes de la Iglesia» ${ }^{203}$.

En segundo término, San Juan Pablo II pone en guardia contra el positivismo legalista que identifica el Derecho con la ley, manifestando que si bien es cierto que la intención que ha presidido la nueva Codificación «fue, obviamente, la de poner a disposición de los pastores y de todos los fieles un instrumento normativo claro, que contuviera los aspectos esenciales del orden jurídico», sin embargo, sería «completamente simplista y erróneo concebir el derecho de la Iglesia como un mero conjunto de textos legislativos, según la perspectiva del positivismo jurídico. En efecto, las normas canónicas se refie-

${ }^{201}$ El texto continúa: «in ció, tuttavia, la legge umana viene valorizzata in quanto espressione di giustizia, anzitutto per quanto essa dichiara come diritto divino, ma anche per quello che essa introduce come legittima determinazione di diritto umano. [...] Il sentire cum Ecclesia ha senso anche nella disciplina, a motivo dei fondamenti dottrinali che sono sempre presenti e operanti nelle norme legali della Chiesa. [...] La maturità cristiana conduce ad amare sempre più la legge e a volerla comprendere ed applicare con fedeltá» (ibid., 105-106).

202 San Juan Pablo II, Discorso ai partecipanti alla giornata accademica organizzata dal Pontificio Consiglio per $i$ Testi legislativi, 24-I-2003, AAS 95 (2003) 333-336.

${ }^{203}$ Ibid., 334. 
ren a una realidad que las trasciende; dicha realidad no sólo está compuesta por datos históricos y contingentes, sino que también comprende aspectos esenciales y permanentes en los que se concreta el derecho divino» ${ }^{204}$.

En tercer lugar, recuerda también que los nuevos Códigos (latino y oriental) deben ser interpretados y aplicados «desde esta perspectiva teológica. De este modo, pueden evitarse ciertos reduccionismos hermenéuticos que empobrecen la ciencia y la praxis canónica, alejándolas de su verdadero horizonte eclesial» ${ }^{205}$.

En un cuarto momento, San Juan Pablo II afirma que «hay que situar el Código en el contexto de la tradición jurídica de la Iglesia. No se trata de cultivar una erudición histórica abstracta, sino de penetrar en ese flujo de vida eclesial que es la historia del derecho canónico, para iluminar la interpretación de la norma. En efecto, los textos del Código se insertan en un conjunto de fuentes jurídicas, que no es posible ignorar sin exponerse al espejismo racionalista de una norma exhaustiva de todo problema jurídico concreto. Esa mentalidad abstracta resulta infecunda, sobre todo porque no tiene en cuenta los problemas reales y los objetivos pastorales que están en la base de las normas canónicas» ${ }^{206}$.

En quinto lugar, hace referencia a un reduccionismo muy peligroso «que pretende interpretar y aplicar las leyes eclesiásticas separándolas de la doctrina del Magisterio. Según esta visión, los pronunciamientos doctrinales no tendrían ningún valor disciplinar, pues sólo habría que reconocer valor a los actos formalmente legislativos. Es sabido que, desde este punto de vista reduccionista, se ha llegado a veces a teorizar incluso dos soluciones diversas del mismo problema eclesial: una, inspirada en los textos magisteriales; la otra, en los canónicos. En la base de ese enfoque hay una idea de Derecho Canónico muy pobre, casi como si se identificara únicamente con el dictamen positivo de la norma. No es así, pues la dimensión jurídica, siendo teológicamente intrínseca a las realidades eclesiales, puede ser objeto de enseñanzas magisteriales, incluso definitivas» ${ }^{207}$.

En sexto término, San Juan Pablo II a partir del «realismo jurídico», afirma por un lado la autonomía científica del Derecho canónico y la necesidad de la interdisciplinariedad: «Este realismo en la concepción del derecho funda una auténtica interdisciplinariedad entre la ciencia canónica y las otras ciencias sa-

\footnotetext{
204 Ibid.

${ }^{205}$ Ibid.

206 Ibid., 334-335.

207 Ibid., 335.
} 
gradas. Un diálogo realmente beneficioso debe partir de esa realidad común que es la vida misma de la Iglesia. La realidad eclesial, aun estudiada desde perspectivas diversas en las varias disciplinas científicas, permanece idéntica a sí misma y, como tal, puede permitir un intercambio recíproco entre las ciencias seguramente útil a cada una» ${ }^{208}$.

En séptimo lugar, menciona que «una de las novedades más significativas del Código de derecho canónico, así como del posterior Código de cánones de las Iglesias orientales, es la normativa que los dos Textos contienen sobre los deberes y los derechos de todos los fieles (cfr. Código de derecho canónico, cc. 208-223; Código de cánones de las Iglesias orientales, cc. 7-20) ${ }^{209}$. En realidad, la referencia de la norma canónica al misterio de la Iglesia, deseada por el Vaticano II (cfr. Optatam totius, 16), pasa también a través de la vía maestra de la persona ${ }^{210}$, de sus derechos y deberes, teniendo presente obviamente el bien común de la sociedad eclesial» ${ }^{211}$.

208 Ibid.

209 Durante la Asamblea General Ordinaria del Sínodo de los Obispos, San Juan Pablo II, en la tarde del jueves 25 de octubre de 1990, pronunció un solemne discurso de presentación del nuevo «Código de los Cánones de las Iglesias Orientales», promulgado el 18 de octubre anterior. En un pasaje de su discurso pedía que todo el Código y cada uno de sus cánones fuese acogido por toda la Iglesia con ánimo sereno y con confianza, especialmente aquellas normas a las que el Papa ha prestado una atención más particular y finalmente decididas así como están en el Código, «porque el Sumo Pontífice las considera necesarias para el bien de la Iglesia universal y para salvaguardar su recto orden y los derechos fundamentales del hombre redimido por Cristo -atque fundamentalia nec praetermittenda iura bominis servanda a Christo redempti-» (AAS 83 (1991) 486-493: 492). A continuación, Mons. Eid, Vicepresidente de la Pontificia Comisión para la revisión del Código de Derecho Canónico Oriental, tuvo una relación para ilustrar a los Padres Sinodales acerca de las características del nuevo Código. Después de hablar del título del nuevo Código, se refirió a su disposición sistemática ya que a diferencia del Código latino y de acuerdo con la tradición oriental se divide en treinta Títulos: «Si è preferito presentare $\mathrm{i}$ trenta titoli del Codice per ordine di priorità sostanziale delle materie espressamente indicate nei titoli [...] Così [...] si è voluto cominciare, nel primo titolo, con i diritti fondamentali dei "Christifideles" (i fedeli cristiani, i battezzati), per presentare dopo successivamente le Chiese in quanto tali [...]» (L'Osservatore Romano, 27-X-1990, p. 7).

210 En su primera Encíclica Redemptor hominis, San Juan Pablo II había ya escrito: «El hombre en la plena realidad de su existencia, de su ser personal y a la vez de su ser comunitario y social [...] este hombre es el primer camino que la Iglesia debe recorrer en el cumplimiento de su misión, él es el camino primero y fundamental de la Iglesia, camino trazado por Cristo mismo, vía que inmutablemente conduce a través del misterio de la Encarnación y de la Redención. [...] Este hombre es el camino de la Iglesia, camino que conduce en cierto modo al origen de todos aquellos caminos por los que debe caminar la Iglesia, porque el hombre -todo hombre sin excepción alguna- ha sido redimido por Cristo [...]» (SAN JUAN PABLO II, Enc. Redemptor hominis, cit., n. 14, 284-285; versión en lengua castellana en http://w2.vatican.va/content/john-paul-ii/es/ encyclicals/documents/hf_jp-ii_enc_04031979_redemptor-hominis.html).

211 San Juan Pablo II, Discorso..., cit., 335. 
Y en fin, en un octavo punto, después de calificar-como consecuencia de lo afirmado inmediatamente antes- la Ecclesiología del Vaticano II como «personalista», recuerda el necesario servicio específico de la Jerarquía: «Precisamente esta dimensión personalista de la eclesiología conciliar permite comprender mejor el servicio específico e insustituible que la Jerarquía eclesiástica debe prestar para el reconocimiento y la tutela de los derechos de las personas y de las comunidades que componen la Iglesia. Ni en la teoría ni en la práctica se puede prescindir del ejercicio de la potestas regiminis y, más en general, de todo el munus regendi jerárquico, como camino para declarar, determinar, garantizar y promover la justicia intraeclesial». A continuación añade los instrumentos típicos del ejercicio de la «potestad» y los posibles malentendidos acerca de ellos: «Todos los instrumentos típicos a través de los cuales se ejerce la potestas regiminis -leyes, actos administrativos, procesos y sanciones canónicas- adquieren así su verdadero sentido, el de un auténtico servicio pastoral en favor de las personas y de las comunidades que forman la Iglesia. A veces este servicio puede ser mal interpretado y contestado: precisamente entonces resulta más necesario para evitar que, en nombre de presuntas exigencias pastorales, se tomen decisiones que pueden causar e incluso favorecer inconscientemente auténticas injusticias» ${ }^{212}$.

En las vísperas del Concilio Vaticano II y en los inicios de la segunda Codificación se proponía - como se ha visto en las páginas precedentes- una concepción integradora de la Ciencia del Derecho canónico, que de la centralidad de la ley daba paso al primado de la persona (de la dignidad y libertad del miembro del Pueblo de Dios, de sus derechos y deberes fundamentales...). Estos ocho puntos sobre el Derecho de la Iglesia en los que he resumido el importante y solemne discurso de San Juan Pablo II de 24 de enero de 2003, recuerdan algunos aspectos de esa propuesta y concepción integradora que continúa siendo un objetivo de la ciencia del Derecho canónico contemporánea. La doctrina en que esa propuesta se fundamentó sigue siendo fecunda para cooperar -como en los difíciles años posteriores al Concilio Vaticano IIa que la Justicia y la Caridad reinen siempre en el nuevo Pueblo de Dios, Cuerpo Místico de Cristo y Templo del Espíritu Santo, que es la Iglesia.

212 Ibid., 335-336. 


\section{Bibliografía}

\section{FUENTES}

Archives Msgr. Willy Onclin, Faculty of Canon law, Leuven [Leuven, CaNON LaW, Willy Onclin].

Archivo General de la Prelatura del Opus Dei, Roma [AGP]: sec. ADP [Álvaro del Portillo], D; y sec. B.1, n. 5165.

BENEDICTO XV, Motu proprio Cum iuris canonici, 15-IX-1917, AAS 9 (1917) 483-484.

BENEDICTO XVI, Discorso in occasione dell'inaugurazione dell'anno giudiziario del Tribunale della Rota Romana, 21-I-2012, AAS 104 (2012) 103-107.

Codex Canonum Ecclesiarum Orientalium, 1990, AAS 82 (1990) 10451364.

Codex IURIS Canonici 1917, AAS 9 (1917) Pars II.

Codex Iuris Canonici 1983, AAS 75 (1983) Pars II.

Concilio Ecuménico Vaticano II, Constitución Lumen Gentium, 21-XI1964, AAS 57 (1965) 5-75.

—, Constitución Gaudium et spes, 7-XII-1965, AAS 58 (1966) 1025-1120.

—, Declaración Dignitatis humanae, 7-XII-1965, AAS 58 (1966) 926-946.

Congregatio de Causis SANCTORUM, Decreto sobre el ejercicio de las virtudes del Siervo de Dios Fosemaría Escrivá de Balaguer, 9-IV-1990, AAS 82 (1990) 1450-1455.

Congregatio de Institutione Catholica (de Seminarits atque StuDiORum Institutis), Decreto Novo Codice - Quo Ordo Studiorum in Facultatibus Iuris Canonici innovatur, 2-IX-2002, AAS 95 (2003) 281-285.

Congregatio [SACra] de SeminariIs et de Studiorum Universitatibus, Instrucción Cum novum iuris - De novo Iuris Canonici Codice in Scholis proponendo, 7-VIII-1917, AAS 9 (1917) 439.

-, Decreto Legum canonicarum Codice - De experimentis ad gradus in Iure Canonico assequendos, 31-X-1918, AAS 11 (1919) 19.

—, Ordinationes ad Constitutionem Apostolicam «Deus scientiarum Dominus» de Universitatibus et Facultatibus Studiorum Ecclesiasticorum rite exsequendam, 12-VI-1931, AAS 23 (1931) 263-284.

Congregatio [Sacra] Pro Institutione Catholica, Ordinationes ad Constitutionem Apostolicam «Sapientia christiana» rite exsequendam, 29-IV-1979, AAS 71 (1979) 500-521. 
Francisco (PAPA), Exhortación Apostólica Evangelii gaudium, 24-XI-2013, AAS 105 (2013) 1019-1137.

Juan Pablo II (SAN), Encíclica Redeptor hominis, 4-III-1979, AAS 71 (1979) 254-324.

-, Constitución Apostólica Sapientia christiana - De Universitatibus et Facultatibus ecclesiasticis, 15-IV-1979, AAS 71 (1979) 469-499.

—, Discorso in occasione della presentazione del Codice dei Canoni delle Chiese Orientali, 25-X-1990, AAS 83 (1991) 486-493.

—, Discorso ai partecipanti alla giornata accademica organizzata dal Pontificio Consiglio per $i$ Testi legislativi, 24-I-2003, AAS 95 (2003) 333-336.

Pablo VI (Beato), Encíclica Ecclesiam suam, 6-VIII-1964, AAS 56 (1964) 609-659.

—, Udienza Generale, 17-VIII-1966, AAS 58 (1966) 800-801.

—, Discorso nel $50^{\circ}$ della promulgazione del Codice de Diritto Canonico, 27-V-1967, Insegnamenti di Paolo VI, vol. V, 1967, Typis Polyglottis Vaticanis, Città del Vaticano 1968, 952-953.

Pío XI, Constitución Apostólica Deus scientiarum Dominus - De Universitatibus et Facultatibus Studiorum Ecclesiasticorum, 24-V-1931, AAS 23 (1931) 241-262.

Pontificia Commissio Codici IURIs CANONICI Recognoscendo, Quaestiones fundamentales, Typis Polyglottis Vaticanis, Città del Vaticano 1965.

-, Principia quae Codicis Iuris Canonici dirigant, Typis Polyglottis Vaticanis, Città del Vaticano 1967.

—, Principia quae Codicis Iuris Canonici recognitionem dirigant a Pontificia Commissione proposita et primi generalis coetus «Synodi Episcoporum» examini subiecta, Typis Polyglottis Vaticanis, Città del Vaticano 1967.

—, Schema Legis Ecclesiae Fundamentalis cum relatione, Typis Polyglottis Vaticanis, Città del Vaticano 1969.

—, Schema Legis Ecclesiae Fundamentalis. Textus enmendatus cum relatione de ipso schemate deque emendationibus receptis, Typis Polyglottis Vaticanis, Città del Vaticano 1971.

\section{AUTORES}

Álvarez de las Asturias, N., Il Codice di Diritto Canonico del 1917 quale oggetto storico, Ius Ecclesiae 23 (2011) 745-763. 
—, Derecho canónico y codificación: Alcance y límites de la asunción de una técnica, Ius Canonicum 51 (2011) 105-136.

—, Recensión a C. FantaPPIÈ, Ecclesiologia e Canonistica, Venezia 2015, 439 pp., Revista Española de Teología 76 (2016) 530-535.

Astorri, R., La canonistica di fronte al CIC 17, en A. CATTANEO (ed.), L'eredità giuridica di San Pio X, Venezia 2006, 173-183.

Ateneo Romano della SANTA Croce (ed.), Rendere amabile la verità. Raccolta di scritti di Mons. Álvaro del Portillo, pastorali, teologici, canonistici, vari, LEV, Città del Vaticano 1995.

BAURA, E., La realtà disciplinata quale criterio interpretativo giuridico della legge, Ius Ecclesiae 24 (2012) 705-717.

Bender, L., Normae generales de personis. Commentarius in canones 87-106, Roma-Parigi-New York-Tournai 1957.

—, Persona in Ecclesia-Membrum Ecclesiae, Apollinaris 32 (1959) 105-119.

Berlingò, S., Il concetto di Diritto Canonico nella scuola laica italiana, en C. J. Errázuriz M. - L. Navarro (eds.), Il Concetto di Diritto Canonico. Storia e prospettive, Milano 2000, 47-69.

BERNAL, J., Temas fundamentales sobre el Derecho canónico y sus sujetos en los escritos de Pedro Lombardía, Fidelium Iura 6 (1996) 83-139.

Boelens, O. G. M., Synopsis «Lex Ecclesiae Fundamentalis», Leuven 2001.

Calasso, F., Medio Evo del Diritto, vol. I, Le fonti, Milano 1954.

CANOSA, J., La tutela giuridica della dignità e della libertà dei fedeli cristiani nonché del carattere ministeriale della Gerarchia. Riflessioni circa il contributo di Álvaro del Portillo per lo sviluppo del diritto amministrativo canonico, en P. GEFAELL (ed.), Vir fidelis multum laudabitur. Nel centenario della nascita di Mons. Álvaro del Portillo, vol. II, Roma 2014, 535-546.

Cenalmor, D., La Ley Fundamental de la Iglesia. Historia y análisis de un proyecto legislativo, Pamplona 1991.

Ciprotti, P., Considerazioni sul «Discorso generale sull'ordinamento canonico» di Pio Fedele, Firenze 1941.

—, Personalità e battesimo nel diritto della Chiesa, Il diritto ecclesiastico 53 (1942) 273-276.

—, Lezioni di Diritto Canonico, Padova 1943.

—, De vocabulorum usu ad ius subiectivum designandum in Codice Iuris Canonici, en EPHeMERIDEs IURIS CANONICI (ed.), Acta Congressus Internationalis Iuris Canonici (Romae, in aedibus Pont. Universitatis Gregorianae 25-30 septembris 1950), Romae 1953, 57-61. 
Clavell, L., La libertà conquistata da Cristo sulla Croce. Approccio teologico ad alcuni insegnamenti del Beato Fosemaría Escrivá sulla libertà, Romana 33 (2001) 240-269.

Conte a Coronata, M., Institutiones Iuris Canonici, vol. I, Taurini ${ }^{4} 1950$.

Dalla Torre, G., Rileggendo un clasico della letteratura canonistica scritto da Álvaro del Portillo. Lo «status» giuridico dei laici e dei fedeli nella Chiesa, L'Osservatore Romano, 27-VI-1999, p. 7.

—, Pio X e il Codice di diritto canonico, Archivio Giuridico 221 (2001) 55-75 y en G. La Bella (ed.), Pio X e il suo tempo, Bologna 2003, 311-332.

De Castro, F., Derecho Civil de España, Parte General, II-I, Madrid 1952.

DE ECHEVERRía, L., Exposición de conjunto de la actual bibliografía canónica, Vitoria 1955.

De Fuenmayor, A., Portillo y Diez de Sollano, Álvaro del, en R. Domingo (ed.), Furistas Universales, vol. IV, Juristas del Siglo XX, Madrid-Barcelona 2004, 778-779.

De la Hera, A., Introducción a la Ciencia del Derecho Canónico, Madrid 1967.

—, Dos maestros de la ciencia canónica de la segunda mitad del siglo XX - Perfil bumano y personalidad científica de Pedro Lombardía y Eugenio Corecco, en J. I. Arrieta - G. P. Milano (eds.), Metodi, fonti e soggetti del Diritto Canonico, Città del Vaticano 1999, 19-31.

Del Giudice, V., Nociones de Derecho Canónico, Pamplona 1955.

—, Nozioni di diritto canonico, Milano ${ }^{12} 1970$.

Del PorTILlo (BEATO), Á., Introducenda in iure canonico de laicorum notione deque eorum iuribus et officiis in Ecclesia, Romae, 2 Octobris 1966 (pro manuscripto), 153 fols., en AGP [Archivo General de la Prelatura del Opus Dei], sec. B.1, n. 5165, XVII-1-6; y en LeUven, FaCUlTy of CANON LaW, Archives Msgr, Willy Onclin, IV, n. 5.

—, Fieles y laicos en la Iglesia. Bases de sus respectivos estatutos jurídicos, Eunsa, Pamplona ${ }^{1} 1969$ (Eunsa, Pamplona ${ }^{3} 1991$ ).

Del Pozzo, M., L'evoluzione della nozione di diritto nel pensiero canonistico di Favier Hervada, Roma 2005.

—, Il contributo documentale di Álvaro del Portillo al progetto della «Lex Ecclesiae Fundamentalis» (1966-1973), en P. GEFAELL (ed.), Vir fidelis multum laudabitur. Nel centenario della nascita di Mons. Alvaro del Portillo, vol. II, Roma 2014, 501-516.

—, Il pensiero costituzional-canonistico di Álvaro del Portillo, Ius Ecclesiae 26 (2014) 289-310. 
DE LuCA, L., I diritti fundamentali dell'uomo nell'ordinamento canonico, en EPHEMERIDES IURIS CANONICI (ed.), Acta Congressus Internationalis Iuris Canonici (Romae, in aedibus Pont. Universitatis Gregorianae 25-30 septembris 1950), Romae 1953, 88-103.

Echevarría, J., In memoriam, en Ateneo Romano della Santa Croce (ed.), Rendere amabile la verità. Raccolta di scritti di Mons. Álvaro del Portillo, pastorali, teologici, canonistici, vari, LEV, Città del Vaticano 1995, 9-23.

EID, E., Relatio in aula Synodi episcoporum habita: de novo Codice Canonum Ecclesiarum Orientalium, 25-X-1990, L'Osservatore Romano, 27-X-1990, 7.

EPHEMERIDES IURIS CANONICI (ed.), Acta Congressus Internationalis Iuris Canonici (Romae, in aedibus Pont. Universitatis Gregorianae 25-30 septembris 1950), Romae 1953.

ERDÖ, P., Introductio in historiam scientiae canonicae. Praenotanda ad Codicem, Roma 1990.

ERrázuriz M., C. J., Un rapporto vitale con il diritto della Cbiesa, en ATENEO Romano Della SANTA Croce (ed.), Rendere amabile la verità. Raccolta di scritti di Mons. Álvaro del Portillo, pastorali, teologici, canonistici, vari, LEV, Città del Vaticano 1995, 439-449.

—, La persona nell'ordinamento canonico: il rapporto tra persona e diritto nella Chiesa, Ius Ecclesiae 10 (1998) 3-36.

-, Corso fondamentale sul diritto nella Chiesa. I. Introduzione. I soggetti ecclesiali di Diritto, Milano 2009.

EsCrivá de Balaguer (SAN), J., Espontaneidad y pluralismo en el Pueblo de Dios, entrevista concedida a P. RODRíGUEZ para la revista Palabra, octubre 1967 y recogida en Conversaciones con Mons. Escrivá de Balaguer, Madrid ${ }^{1} 1968$, en J. L. Illanes - A. MÉNDIZ (eds.), Conversaciones con Mons. Escrivá de Balaguer. Edición crítico-bistórica, Rialp, Madrid 2012, 143-201.

—, La libertad, don de Dios, en IdEM, Amigos de Dios, Madrid 1977, nn. 23-38.

Escrivá Ivars, J. - HervadA, J., Relectura de la obra científica de favier Hervada, vols. I-III, Pamplona 2008-2009, en http://www.javierescriva.com/?p=172.

FABRO, C., Un maestro di libertà cristiana: Fosemaría Escrivá de Balaguer, L'Osservatore Romano, 2-VII-77, 5.

—, El primado existencial de la libertad, en P. RodríGueZ - P. G. Alves De SouSA - J. M. Zumaquero (eds.), Mons. Fosemaría Escrivá de Balaguer y el Opus Dei (en el 50 aniversario de su fundación), Pamplona 1982, 341-356.

-, La tempra di un Padre della Chiesa, en C. FABro - S. Garofalo - M. A. RASCHINI, Santi nel mondo - Studi sugli scritti del beato Fosemaría Escrivá, Milano 1992, 22-155. 
FalCO, M., Introduzione allo studio del «Codex iuris canonici» (Torino $\left.{ }^{1} 1925\right)$, G. Feliciani (ed.), Bologna ${ }^{2} 1992$.

FANTAPPIÈ, C., Gli inizi della codificazione pio-benedettina alla luce di nuovi documenti, Il diritto ecclesiastico 93 (2002) 16-83.

—, Pio X e il «Codex iuris canonici», en A. CatTANeO (ed.), L'eredità giuridica di San Pio X, Venezia 2006, 155-171.

—, Chiesa Romana e modernità giuridica, Milano 2008.

-, Per la storia della codificazione canonica (A cento anni del suo avvio), Ius Ecclesiae 16 (2014) 41-65.

—, Ecclesiologia e Canonistica, Venezia 2015.

Fedele, P., Discorso generale sull'ordinamento canonico, Padova 1941.

-, Il problema del diritto soggettivo e dell'azione in relazione al problema della distinzione tra diritto pubblico e diritto privato nell'ordinamento canonico, en EPHemerides IURIS CANONICI (ed.), Acta Congressus Internationalis Iuris Canonici (Romae, in aedibus Pont. Universitatis Gregorianae 25-30 septembris 1950), Romae 1953, 116-126.

—, Lo spirito del diritto canonico, Padova 1962.

Feliciani, G., Il Concilio Vaticano I e la codificazione del diritto canonico, en Studi in onore di Ugo Gualazzini, vol. II, Milano 1981, 35-80.

-, Lineamenti di ricerca sulle origini della codificazione canonica vigente, en Università di Macerata. Annali della Facoltà di Giurisprudenza in onore di Attilio Moroni, n.s., vol. V, t. I, Milano 1982, 205-225.

—, La scuola canonistica italiana dal dogmatismo giuridico al post-concilio, en Scienza giuridica e diritto canonico, Torino 1991, 61-80.

—, Il Cardinale Gasparri e la codificazione del diritto canonico, en Studi in onore di Gaetano Catalano, vol. I, Soveria Mannelli 1998, 563-587.

—, «Codex Iuris Canonici (1917)», en J. OTADUY - A. Viana - J. SEdano (eds.), Diccionario General de Derecho Canónico, vol. II, Aranzadi, Pamplona 2012, 167-172.

ForNÉs, J., La noción de «status» en Derecho canónico, Eunsa, Pamplona 1975.

—, La ciencia canónica contemporánea (Valoración crítica), Eunsa, Pamplona 1984.

—, Derecho y libertad en el pensamiento de Pedro Lombardía, Ius Canonicum 74 (1997) 489-504.

GASPARRI, P., Storia della codificazione del diritto canonico per la Chiesa latina, en Acta Congressus Iuridici Internationalis VII saeculo a Decretalibus Gregorii IX et XIV a Codice Iustiniano promulgatis, Romae 12-17 novembris 1934, vol. IV, Romae 1937, 3-10. 
GHERRI, P., Il primo Codice di diritto canonico: fu vera codificazione?, Apollinaris 76 (2003) 827-898.

GIACCHI, O., Diritto canonico e dogmatica giuridica moderna, Il Foro italiano 64 (1939) 161-187.

GISMONDI, P., Gli acattolici nel diritto della Chiesa, Ephemerides iuris canonici 2 (1946) 224-249.

GómeZ-Iglesias C., V., Acerca de la autoridad como servicio en la Iglesia, en Pontificium Consilium de Legum TeXTibus interpretandis (ed.), Ius in vita et in missione Ecclesiae, Acta Symposii Internationalis Iuris Canonici occurrente X Anniversario promulgationis Codicis Iuris Canonici diebus 19-24 aprilis 1993 in Civitate Vaticana celebrati, Città del Vaticano 1994, 193-217.

-, Libertad y Derecho Constitucional en Pedro Lombardía, Eunsa, Pamplona 1998.

—, O projecto de Lex Ecclesiae Fundamentalis, en Deveres e Direitos dos Fiéis na Igreja, Lusitania Canonica 5, Lisboa 1999, 247-275.

—, La Pontificia Commissio Codici Iuris Canonici Recognoscendo en los años del Concilio Ecuménico Vaticano II: el plan de revisión de las leyes de la Iglesia, Ius Canonicum 42 (2002) 109-133.

-, Acerca de la contribución de Álvaro del Portillo al Derecho de la Iglesia, Ius Canonicum 54 (2014) 459-517 y en M. Alonso De Diego (ed.), El beato Álvaro del Portillo y la Universidad, Pamplona 2016, 62-110.

-, Acerca de la trascendencia bistórica de la iniciativa de San Pío X de elaborar un Código de Derecho canónico, Ius Ecclesiae 29 (2017) 51-76.

—, La ricezione del Codice del 1917 nella dottrina e nell'insegnamento, en E. BAURA - N. Álvarez DE las ASTURIAS - T. SOL (eds.), La Codificazione e il Diritto nella Chiesa, Milano 2017, 71-119.

González Alonso, Á., La definición de laico en el Código de Derecho Canónico de 1983, Roma 2014.

—, Mons. Álvaro del Portillo y el Coetus Studiorum «De Laicis»: bases conceptuales para una definición del fiel laico en la Iglesia, en P. GEFAELL (ed.), Vir fidelis multum laudabitur. Nel centenario della nascita di Mons. Álvaro del Portillo, vol. II, Roma 2014, 335-350.

GRossi, P., Storia della canonistica moderna e storia della codificazione, Quaderni fiorentini per la storia del pensiero giuridico moderno 14 (1985) 587-599.

-, Valori e limiti della codificazione del diritto (con qualche annotazione sulla scelta codicistica del legislatore canonico), en A. CATTANEO (ed.), L'eredità giuridica di San Pio X, Venezia 2006, 141-154. 
GuTIÉRREZ, J. L., Situación presente y perspectivas futuras de la ley fundamental de la Iglesia, Ephemerides Iuris Canonici 27 (1971) 273-295 y en IDEM, Estudios sobre la organización jerárquica de la Iglesia, Pamplona 1987, 119-143.

—, Mons. Alvaro del Portillo e la codificazione canonica, en P. GEFAELl (ed.), Vir fidelis multum laudabitur. Nel centenario della nascita di Mons. Alvaro del Portillo, vol. I, Roma 2014, 103-131.

Herranz, J., Il Prof. Pedro Lombardía e la nuova codificazione canonica, Ius Canonicum 26 (1986) 507-513.

Herrera Pardo, C., Aproximación a los fundamentos científicos y filosóficos del iusnaturalismo realista de Favier Hervada, Capítulo II: La Escuela de Lombardía y su aportación crítica a la canonistica del siglo XX, Pamplona 2016, 95-216.

Hervada, J., La impotencia del varón en el Derecho matrimonial canónico, Pamplona 1959.

-, Los fines del matrimonio. Su relevancia en la estructura jurídica matrimonial, Pamplona 1960.

—, El matrimonio in facto esse. Su estructura jurídica, Ius Canonicum 1 (1961) $135-175$.

-, Reflexiones acerca de la prudencia jurídica y el Derecho Canónico, Revista Española de Derecho Canónico 16 (1961) 415-451.

-, Fin y características del Derecho Canónico (Notas en torno al tema), Ius Canonicum 2 (1962) 5-110.

—, La relación de propiedad en el patrimonio eclesiástico, Ius Canonicum 2 (1962) 425-467.

-, La ordinatio ad fines en el matrimonio canónico, Revista Española de Derecho Canónico 18 (1963) 439-499.

- El concepto de ordenamiento canónico en la doctrina contemporánea, Ius Canonicum 5 (1965) 5-61.

—, Persona, Derecho y fusticia, en IDEM, Vetera et nova. Cuestiones de Derecho Canónico y afines (1958-2004), Pamplona 22005, 235-245.

—, Personalidad científica de Pedro Lombardía, Ius Canonicum 26 (1986) 491-496.

-, Los derechos fundamentales del fiel a examen, en IDEM, Vetera et nova. Cuestiones de Derecho Canónico y afines (1958-2004), Pamplona 22005, 681-715.

—, La dignidad y libertad de los hijos de Dios, en IDEM, Vetera et nova. Cuestiones de Derecho Canónico y afines (1958-2004), Pamplona 22005, 745-760.

—, Confesiones de un canonista, Fidelium Iura 12 (2002) 61-68.

Hervada, J. - Lombardía, P., El Derecho del Pueblo de Dios. Hacia un sistema de Derecho Canónico, vol. I, Introducción. La Constitución de la Iglesia, Pamplona 1970. 
Iban, I. C., Derecho Canónico y Ciencia furídica, Madrid 1984.

KuTtNer, S., Il Diritto canonico nella storia, Jus 18 (1967) 239-254.

Llobell, J. - De León, E. - Navarrete, J., Studio introduttivo, en Idem, Il libro «De processibus» nella codificazione del 1917, vol. I, Milano 1999, 17-228.

Lo CASTRO, G., Il soggetto e i suoi diritti nell'ordinamento canonico, Milano 1985.

—, Il Mistero del Diritto. II. Persona e Diritto nella Chiesa, Torino 2011.

LOMBARDía, P., Los matrimonios mixtos en la Iglesia cartaginesa del siglo III, en IDEM, Escritos de Derecho Canónico, vol. I, Pamplona 1973, 51-72.

-, Los matrimonios mixtos en el Concilio de Elvira (a. 303?) (Notas para la historia del matrimonio canónico), en IDEM, Escritos de Derecho Canónico, vol. I, Pamplona 1973, 73-94.

—, Sobre la enseñanza universitaria y el método de estudio del Derecho Canónico, en IDEM, Escritos de Derecho Canónico, vol. I, Pamplona 1973, 95-111.

-, Los matrimonios mixtos en el Derecho de la Iglesia Visigoda, en IDEM, Escritos de Derecho Canónico, vol. I, Pamplona 1973, 113-172.

-, Sobre las características peculiares del ordenamiento canónico, en IDEM, Escritos de Derecho Canónico, vol. I, Pamplona 1973, 177-191.

-, Derecho divino y persona física en el ordenamiento canónico, en IDEM, Escritos de Derecho Canónico, vol. I, Pamplona 1973, 223-253.

-, Observaciones sobre el método en el estudio del matrimonio canónico, en IDEM, Escritos de Derecho Canónico, vol. I, Pamplona 1973, 255-278.

-, El Derecho canónico en las Facultades de Derecho, en IDEM, Escritos de Derecho Canónico, vol. I, Pamplona 1973, 288-306.

—, La sistemática del Codex y su posible adaptación, en IDEM, Escritos de Derecho Canónico, vol. I, Pamplona 1973, 347-395.

-, El estatuto personal en el ordenamiento canónico. Fundamentos doctrinales, en IDEM, Escritos de Derecho Canónico, vol. II, Pamplona 1973, 33-62.

-, Los laicos en el derecho de la Iglesia, en IDEM, Escritos de Derecho Canónico, vol. II, Pamplona 1973, 151-204.

-, El Derecho en el actual momento de la vida de la Iglesia, en IDEM, Escritos de Derecho Canónico, vol. II, Pamplona 1973, 433-455.

-, Una monografía sobre los derechos fundamentales del fiel, en IDEM, Escritos de Derecho Canónico, vol. III, Pamplona 1973, 107-119.

—, Un hombre de Dios, Nuestro Tiempo 257 (1975) 371-383.

-, Acerca del sentido de dos noticias, en IDEM, Escritos de Derecho Canónico y de Derecho Eclesiástico del Estado, vol. IV, Pamplona 1991, 97-134. 
-, Norma y ordenamiento jurídico en el momento actual de la vida de la Iglesia, en IDEM, Escritos de Derecho Canónico y de Derecho Eclesiástico del Estado, vol. IV, Pamplona 1991, 191-215.

-, Los derechos fundamentales del cristiano en la Iglesia y en la sociedad, en IDEM, Escritos de Derecho Canónico y de Derecho Eclesiástico del Estado, vol. IV, Pamplona 1991, 493-515.

—, Téenica jurídica del nuevo Código (Una primera aproximación al tema), en IDEM, Escritos de Derecho Canónico y de Derecho Eclesiástico del Estado, vol. V, Pamplona 1991, 187-221.

-, Amor a la Iglesia, en IDEM, Escritos de Derecho Canónico y de Derecho Eclesiástico del Estado, vol. V, Pamplona 1991, 467-502.

-, Contribución a la teoría de la persona física en el ordenamiento canónico, en IDEM, Escritos de Derecho Canónico y de Derecho Eclesiástico del Estado, vol. V, Pamplona 1991, 581-685.

Martínez-Torrón, J. - De la Hera, A., Pedro Lombardía. A los treinta años de su muerte, Ius Canonicum 56 (2016) 487-512.

MaY, G. - EgLER, A., Einfuibrung in die kirchenrechtliche Methode, Regensburg 1986.

Merry del Val, R., Pio X (Impressioni e ricordi), Padova 1925.

Michiels, G., Principia generalia de personis in Ecclesia, Parisiis-Tornaci-Roma ${ }^{2} 1955$.

Molano, E., La autonomía privada en el ordenamiento canónico, Pamplona 1974.

Motilla, A., La idea de codificación en el proceso de formación del Codex del 1917, Ius Canonicum 28 (1988) 681-720.

Navarro-Valls, R., La figura de Pedro Lombardía, Anuario de Derecho Eclesiástico del Estado 3 (1987) 17-25.

Noval, J., Codificationis juris canonici: recensio bistorico-apologetica et Codicis piano-benedictini notitia generalis; doctrina ad studium novi Codicis Canonici propaedeutica, Romae 1918.

OCÁRIZ, F., Naturaleza, Gracia y Gloria, Pamplona 2000, 20-65.

OlIVERO, G., Intorno al problema del diritto soggettivo nell'ordinamento canonico, Torino 1948.

—, Diritto naturale e diritto della Chiesa, Il diritto ecclesiastico 61 (1950) 1-41.

Otaduy, J., Del Portillo, Álvaro, en J. Otaduy - A. Viana - J. Sedano (eds.), Diccionario General de Derecho Canónico, vol. V, Aranzadi, Pamplona 2012, 1017-1021. 
—, Los medios interpretativos de la ley canónica (y su relación con las distintas doctrinas de la interpretación), en IDEM, Fuentes, Interpretación, Personas, Pamplona 2002, 263-313.

—, Positivismos ingenuos. A propósito del discurso de Benedicto XVI sobre interpretación de la ley canónica (21-I-2012), Ius Canonicum 54 (2014) 23-44.

PADOA Schioppa, A., Storia del diritto in Europa. Dal medioevo all'età contemporanea, Bologna 2007.

Pontificia Università Della SANTA Croce, I principi per la revisione del Codice di Diritto Canónico. La ricezione giuridica del Concilio Vaticano II, J. CANOSA (ed.), Milano 2000.

Prieto, A., El proceso de formación del Derecho canónico, en AA.Vv., Derecho Canónico, Pamplona 1975, 89-138.

REDAELLI, C., Il concetto di diritto della Chiesa nella riflessione canonistica tra Concilio e Codice, Milano 1991.

—, La adozione del principio della codificazione: significato ecclesiologico soprattutto in riferimento alla ricezione, en H. LEGRAND - J. MANZANARES - A. GARCíA Y GARCía (eds.), La recepción y la comunión entre las Iglesias, Salamanca 1997, 315-348.

—, Il metodo esegetico applicato al Codice di Diritto Canonico del 1917 e a quello de 1983, Periodica 86 (1997) 57-100.

-, Codificación [Cuestión de la], en J. Otaduy - A. Viana - J. SEdano (eds.), Diccionario General de Derecho Canónico, vol. II, Aranzadi, Pamplona 2012, 189-196.

Romano, S., L'ordinamento giuridico, Pisa 1918.

RufFINI, F., La codificazione del Diritto ecclesiastico, Prato 1905, en IDEM, Scritti giuridici minori, M. FALCO - A. C. JEMOLO - E. RUFFINI (eds.), vol. I, Milano 1936, 59-97.

SAHLi LeCaros, C., La revisión de las leyes de la Iglesia: contexto doctrinal y primeros pasos del proyecto de una Ley fundamental, Roma 2011.

-, Alvaro del Portillo y los primeros pasos del proyecto de una Ley Fundamental para la Iglesia, en P. GEFAELL (ed.), Vir fidelis multum laudabitur. Nel centenario della nascita di Mons. Álvaro del Portillo, vol. II, Roma 2014, 517-533.

Salinas-Araneda, C., La codificación del Derecho Canónico del 1917, Revista de Derecho de la Pontificia Universidad Católica de Valparaíso 30 (2008) 311-356.

SEDANO, J., Iglesia y modernidad jurídica. Una contribución a la Historia del pensamiento jurídico moderno en la monografía de Carlo Fantappiè, Ius Canonicum 52 (2011) 767-798. 
STICKLER, A. M., Historia juris canonici latini. Institutiones academicae, vol. I, Historia Fontium, Taurini 1950.

—, La funzione della scienza storica di diritto canonico nella codificazione pio benedettina e per la riforma attuale del diritto canonico, L'année canonique 15 (1971) 525-540.

StutZ, U., Der Geist des Codex iuris canonici, Stuttgart 1918.

Thibaut, A. F. J. - Savigny, F. C., La polemica sulla codificazione, G. MarinI (ed.), Napoli 1982.

Torfs, R., Les écoles canoniques, Revue de Droit Canonique 47 (1997) 89-110.

Trueba, S., El Derecho Canónico como un orden de libertad en el pensamiento de Pedro Lombardía, Roma 1989 (pro manuscripto).

VALdÉs Mas, M., La contribución de Álvaro del Portillo en la elaboración del Decreto Presbyterorum Ordinis y en su aplicación jurídica, Roma 2014.

Valdrini, P., Pio X e l'elaborazione del Codex Iuris Canonici, en R. Regoli (ed.), San Pio X papa riformatore di fronte alle sfide del nuovo secolo, Città del Vaticano 2016, 121-130.

Van Hove, A., Commentarium lovaniense in Codicem Iuris Canonici. Prolegomena, Altera, Mechliniae-Romae 1945.

Vetulani, A., «Codex Iuris Canonici», en R. NAZ (ed.), Dictionnaire de droit canonique, vol. III, Paris 1942, 910-935.

Viladrich, P. J., Teoría de los derechos fundamentales del fiel. Presupuestos críticos, Pamplona 1969. 
ESTUDIOS

ESTUDIOS SOBRE EL

MOTU PROPRIO MITIS IUDEX (III) 
